\title{
Kinh nghiệm của 87 quốc gia trong việc xác định và chuyển nhượng quyền Các-bon
}

Phạm Thu Thủy

Hoàng Tuấn Long

Đào Thị Linh Chi

Trần Ngọc Mỹ Hoa

Nguyễn Thị Vân Anh

Nguyễn Thị Thủy Anh

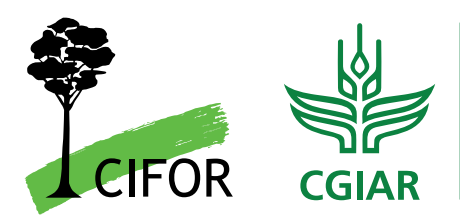





\title{
Kinh nghiệm của 87 quốc gia trong việc xác định và chuyển nhượng quyền Các-bon
}

\author{
Phạm Thu Thủy \\ CIFOR \\ Hoàng Tuấn Long \\ CIFOR \\ Đào Thị Linh Chi \\ CIFOR
}

Trần Ngọc Mỹ Hoa

Đại học Quốc Gia Hà Nội

Nguyễn Thị Vân Anh

Đại học Khoa học xã hội và Nhân văn

Nguyễn Thị Thủy Anh

Học viện Ngoại giao 
Báo cáo chuyên đề 218

C 2021 Tổ chức Nghiên cứu Lâm nghiệp Quốc tế (CIFOR)

Nội dung trong ấn phẩm này được cấp quyền bởi Giấy phép bản quyền Ghi nhận công của tác giả - Phi thương mại, không chỉnh sửa, thay đổi hay phát triển - Không phát sinh 4.0. http://creativecommons.org/ licenses/by-nc-nd/4.0/

ISBN 978-602-387-156-8

DOI: $10.17528 /$ cifor/007992

Phạm TT, Hoàng TL, Đào TLC, Trần NMH, Nguyễn TVA và Nguyễn TTA. 2021. Kinh nghiệm của 87 quốc gia trong việc xác định và chuyển nhượng quyên Các-bon. Báo cáo chuyên đề 218. Bogor, Indonesia: CIFOR.

Ảnh được chụp bởi Ricky Martin/CIFOR

Bé Rosita- 3 tuổi nâng niu cây con trong vườn ươm.

\section{CIFOR}

Jl. CIFOR, Situ Gede

Bogor Barat 16115

Indonesia

$\mathrm{T}+62(251) 8622-622$

$\mathrm{F}+62(251) 8622-100$

E cifor@cgiar.org

\section{cifor.org}

Chúng tôi xin cảm ơn các nhà tài trợ đã hỗ trợ cho nghiên cứu này thông qua việc đóng góp vào quỹ của CGIAR. Xin xem danh sách các nhà tài trợ: http://www.cgiar.org/about-us/our-funders/

Tất cả các quan điểm thể hiện trong ấn phẩm này là của các tác giả. Chúng không nhất thiết đại diện cho quan điểm của CIFOR, các cơ quan chủ quản của tác giả hay của các nhà tài trợ cho ấn phẩm này. 


\section{Mục lục}

Lời cảm ơn $\quad v$

Danh mục từ viết tắt

Tóm tắt tổng quan ii

1 Mở đầu

2 Phương pháp và phạm vi nghiên cứu $\quad 2$

3 Tổng quan về thị trường Các-bon 3

3.1 Thị trường Các-bon quốc tế và Thị trường Các-bon nội địa 3

3.2 Thị trường Các-bon bắt buộc và Thị trường Các-bon tự nguyện 7

3.3 Hàng hóa giao dịch trong thị trường: hạn mức phát thải và bồi hoàn tín chỉ Các-bon

3.4 Định giá Các-bon 10

4 Quy định và khung pháp lí quốc tế liên quan đến quyền Các-bon, quyền phát thải và chia sẻ lợi ích

$\begin{array}{ll}\text { 4.1 Chuyển quyền Các-bon nội địa } & 15 \\ \text { 4.2 Cơ chế chuyển quyền Các-bon và quyên phát thải quốc tế } & 19\end{array}$

5 Kinh nghiệm các quốc gia trên thế giới trong việc xác định và chuyển nhượng quyền Các-bon và giấy chứng nhận giảm phát thải

5.1 Chuyển nhượng quyên Các-bon và chứng nhận giảm phát thải tại các nước đã kí ERPA.

5.2 Chuyển nhượng quyền Các-bon và chứng nhận giảm phát thải tại các nước ở giai đoạn ERPD

5.3 Chuyển nhượng quyền Các-bon và chứng nhận giảm phát thải tại các nước đã nhận được chị trả dựa vào kết quả của Quỹ Khí hậu xanh (GCF)

6 Thảo luận và đề xuất chính sách

6.1 Việt Nam nên hướng tới thị trường Các-bon bắt buộc hay thị trường Các-bon tự nguyện?

6.2 Kết nối giữa thị trường Các-bon nội địa và thị trường Các-bon quốc tế ? 40

6.3 Hợp pháp hóa quyền và chuyển quyền Các-bon/chuyển nhượng kết quả giảm phát thải 


\section{Danh mục hình, bảng và hộp}

\section{Bảng}

1 Số lượng các nước được khảo sát 2

2 Các cơ chế giảm phát thải quốc tế 4

3 Một số cơ chế thị trường Các-bon bắt buộc phổ biến 7

4 Cơ chế thương mại phát thải của Nhật Bản 9

5 Các tiêu chuẩn Các-bon 9

6 Sự khác biệt giữa hai cơ chế hàng hóa Các-bon 10

7 Các quốc gia áp dụng thuế Các-bon 13

8 Các vấn đề cần xem xét khi xây dựng chính sách về quyền Các-bon. 15

9 Ví dụ về chính sách liên quan quyên Các-bon ở Brazil và Peru 17

10 Các cơ chế giao dịch giảm phát thải và quy định liên quan đến chuyển quyền và truy xuất giao dịch giảm phát thải

11 Đóng góp và quan điểm của các cổ đông trong Quỹ Các-bon của FCPF

126 quốc gia nhận được chi trả dựa vào kết quả từ Quỹ GCF 24

13 Các nước đã kí ERPA/FCPF 27

14 Các nước đã kí ERPA/FCPF và hệ thống đăng kí, chuyển nhượng quyền
Các-bon của họ

15 Chính sách quyền Các-bon gắn với sở hữu đất đai 33

16 Chuyển nhượng quyền các-bon và chứng nhận giảm phát thải tại các nước ở giai đoạn ERPD $\quad 35$

17 Chuyển quyền các-bon và giảm phát thải tại các nước đã nhận được chi trả dựa vào kết quả của quỹ khí hậu xanh

Hộp

1 Một số thị trường các-bon nội địa trên thế giới

2 Những điều khoản quan trọng của Thỏa Thuận Paris quyết định cơ chế vận hành của chuyển giao quyền Các-bon và chứng nhận giảm phát thải nhửng chưa được làm rõ

3 Điều kiện để nhận được chi trả dựa vào kết quả của GCF

\section{Hình}

1 Giá bán Các-bon trên các thị trường Các-bon tự nguyện 11

2 Giá trị của thị trường Các-bon giai đoạn 2030-2050 (Đơn vị: triệu USD) 11

3 Cơ chế chuyển quyền Các-bon và giấy chửng nhận giảm phát thải 19

4 Thực trạng của các nước kí FCPFs tới thời điểm 26 tháng 2 năm 2021

5 Các nước đã kí FCPF theo khu vực và theo các giai đoạn kí kết của FCPF 26

63 phương thức chính mà các Bên thực thi chương trình có thể chứng minh
có khả năng chuyển quyền ER

7 Khung pháp lí tại các nước ERPA trong việc chuyển nhượng quyền Các-bon $\quad 28$

8 Các hình thức xây dựng quyền chuyên các-bon của các quốc gia 36 


\section{Lời cảm ơn}

Chúng tôi xin trân trọng cảm ơn hỗ trợ tài chính từ các nhà tài trợ bao gồm Cơ quan Hợp tác Phát triển $\mathrm{Na}$ Uy (NORAD), Cơ quan phát triển Mỹ (USAID) thông qua dự án Quản lí giảm thiểu và thích ứng biến đổi khí hậu đối với các vùng đất ngập nước (SWAMP) và Chương trình nghiên cứu CGIAR về rừng, cây và nông lâm kết hợp (CRP-FTA), đã hỗ trợ nghiên cứu này. 


\section{Danh mục từ viết tắt}

\begin{tabular}{|c|c|}
\hline AAU & Đơn vị lượng được ấn định \\
\hline CBEEX & Sàn giao dịch Môi trường Bắc Kinh Trung Quốc \\
\hline $\mathrm{CDM}$ & Cơ chế phát triển sạch \\
\hline CER & Đơn vị giảm phát thải được chứng nhận \\
\hline CFEX & Sàn giao dịch Lâm nghiệp Trung Quốc \\
\hline CFP & Các thành viên đóng góp chính cho FCPF \\
\hline CORSIA & Chương trình bù đắp và giảm thiểu Các-bon cho hàng không quốc tế \\
\hline ERPAs & Thỏa thuận chi trả cho giảm phát thải \\
\hline ER & Giảm phát thải \\
\hline ERU & Đơn vị giảm phát thải \\
\hline EU & Châu Âu \\
\hline EU-ETS & Hệ thống hạn mức phát thải và thương mại Châu Âu \\
\hline FAS & Quỹ bền vững Amazonas \\
\hline FCPF & Quỹ các bon \\
\hline GCF & Quỹ khí hậu xanh \\
\hline GS & Tiêu chuẩn vàng \\
\hline ICAO & Tổ chức Hàng không Dân dụng Quốc tế \\
\hline INDC & Cam kết dự kiến quốc gia tự quyết định \\
\hline ITMOs & Chuyển giao kết quả giảm thiểu biến đổi khí hậu trên toàn câu \\
\hline KNK & Khí nhà kính \\
\hline NDC & Cam kết quốc gia tự quyết định \\
\hline NGO & Tổ chức phi chính phủ \\
\hline NZ ETS & Hệ thống thương mại của New Zealand \\
\hline NZU & Đơn vị New Zealand \\
\hline OECD & Tổ chức hợp tác và phát triển kinh tế \\
\hline PAM & Chính sách và biện pháp \\
\hline PES & Chi trả dịch vụ môi trường \\
\hline PS & Tiêu chuẩn Panda \\
\hline REDD+ & Giảm phát thải từ mất rừng và suy thoái rừng \\
\hline REM & Những người tiên phong \\
\hline RGGI & Sáng kiến về khí nhà kính khu vực \\
\hline RMU & Đơn vị loại bỏ \\
\hline $\mathrm{tCO}_{2}$ & Tấn các bon \\
\hline UK-ETS & Hệ thống thương mại của UK \\
\hline UNFCCC & Công ước khung Liên Hiệp Quốc về Biến đổi Khí hậu \\
\hline VCM & Thị trường Các-bon tự nguyện \\
\hline VCS & Tiêu chuẩn Các-bon tự nguyện \\
\hline VCUs & Đơn vị Các-bon được thẩm định \\
\hline WCI & Sáng kiến Khí hậu Phương Tây \\
\hline
\end{tabular}




\section{Tóm tắt tổng quan}

Giảm phát thải khí nhà kính từ phá rừng và suy thoái rừng $(\mathrm{REDD}+)$ được cộng đồng quốc tế và nhiều quốc gia đánh giá là chiến lược quan trọng và hiệu quả trong cuộc chiến chống biến đổi khí hậu. Chi trả dựa vào kết quả đối với các dự án giảm phát thải nói chung và với các dự án REDD+ nói riêng đã được đề xuất từ năm 2009 và đã có sự cải thiện đáng kể về hệ thống theo dõi, giám sát, thẩm định và đánh giá kết quả làm tiền đề cho chi trả trong 11 năm qua. Tuy nhiên, hiện có rất nhiêu quốc gia, trong đó có Việt Nam đang gặp khó khăn trong việc xác định quyền và hệ thống chuyển nhượng quyền Các-bon/giấy chứng nhận giảm phát thải.

Dựa vào tài liệu thứ cấp, báo cáo này được tiến hành bởi Tổ chức Nghiên cứu Lâm nghiệp Quốc tế (CIFOR) nhằm rà soát:

- Sự vận hành và định hướng của thị trường Cácbon quốc tế và nội địa trên toàn cầu

- Các quy định quốc tế có liên quan đến quyền Các-bon và chuyển nhượng kết quả giảm phát thải

- Kinh nghiệm của 87 quốc gia trong việc xác định, xây dựng thị trường Các-bon cũng như chính sách liên quan đến quyền và chuyển nhượng quyền Các-bon

Báo cáo chỉ ra rằng, cơ chế vận hành của thị trường Các-bon phụ thuộc vào quy mô (thị trường quốc tế hoặc thị trường nội địa), phạm vi hoạt động (thị trường bắt buộc hoặc thị trường tự nguyện); hàng hóa giao dịch (tín chỉ bôi hoàn Cácbon hoặc hạn mức phát thải) và phương pháp định giá Các-bon. Trong bối cảnh các quy định quốc tế về thương mại Các-bon toàn câu còn chưa được rõ ràng và đang chờ đợi sự thống nhất quy định trong Thỏa thuận Paris, các quốc gia, trong đó có Việt Nam nên tập trung phát triển cả thị trường tự nguyện và thị trường bắt buộc trên quy mô quốc tế và nội địa với các loại hàng hóa hiện có, nhưng ưu tiên phát triển thị trường Các-bon tự nguyện. Kết quả nghiên cứu cũng nhấn mạnh tầm quan trọng của việc gắn kết giữa thị trường Các-bon nội địa (được kì vọng xây dựng qua cơ chế Chi trả dịch vụ môi trường rừng - PFES tại Việt $\mathrm{Nam}$ ) với thị trường các-bon quốc tế thông qua làm rõ tính bổ sung, hoàn thiện hệ thống quản lí PFES nội địa - xây dựng hệ thống đăng kí Các-bon rừng quốc gia để thuận lợi cho việc tham gia thị trường quốc tế, tối ưu hóa nguồn tài chính để hỗ trợ quá trình thẩm định và bán tín chỉ các-bon ra thị trường quốc tế. Đa dạng hóa các công cụ và cơ chế chính sách (ví dụ: xây dựng cơ chế thương mại phát thải và thuế Các-bon) cũng sẽ giúp sự vận hành của thị trường Các-bon nội địa được hiệu quả hơn.

Kết quả nghiên cứu cũng chỉ ra rằng vấn đề xây dựng chính sách liên quan đến quyền và chuyển quyền Các-bon còn mới mẻ trên thế giới và các quốc gia đều đang trong quá trình xây dựng chính sách này. Cho tới nay, phần lớn các nước $(60 \%)$ đã kí được chi trả dựa vào kết quả của Quỹ Các-bon và Quỹ Khí hậu xanh (GCF) tiến hành chuyển quyền các-bon dựa vào hệ thống luật pháp (ví dụ: Luật đất đai, Luật sở hữu và quản lí tài nguyên thiên nhiên) hiện hành. Một số quốc gia khác lựa chọn giải pháp xây dựng quyết định mới hướng dẫn quá trình chuyển quyền Các-bon cho toàn quốc gia áp dụng với tất cả các chương trình giảm phát thải trong đó có thỏa thuận với Quỹ Cácbon. Dù dưới hình thức nào, các quốc gia đều phải làm rõ quyền các-bon bao gồm những quyền hạn nào (quyền sở hữu đối với Các-bon lưu giữ trong đất và rừng? quyền hưởng lợi từ việc cung cấp và bán dịch vụ giảm phát thải? quyên được chuyển nhượng và bán tín chỉ Các-bon/quyền phát thải hay kết hợp của các quyền trên?) cũng như trách nhiệm (nếu không thực hiện đúng như cam kết thì sẽ phải chịu trách nhiệm gì?).

Báo cáo cũng chỉ ra 3 cách tiếp cận của các nước liên quan đến việc quyết định ai là người có quyền sở hữu và chuyển quyền Các-bon. Cụ thể hơn:

- Quyên Các-bon đi theo quyền và phân loại sở hũu đất công tu. Đối với diện tích rừng do 
nhà nước quản lí, Nhà nước sở hữu quyền các-bon tạo ra trên diện tích rừng này. Đối với diện tích rừng do các bên ngoài nhà nước quản lí, quyền các-bon thuộc về chủ sở hữu ngoài nhà nước này. Chính sách như vậy sẽ tạo điều kiện khuyến khích các bên ngoài nhà nước tham gia vào các hoạt động thương mại giảm phát thải. Tuy nhiên, trong thực tế không phải nhóm chủ sở hữu rừng nào cũng có đủ năng lực để làm điều này (đặc biệt cộng đông dân cư) do vậy vẫn cần sự hỗ trợ của nhà nước.

- Quyên tự chủ và tài sản quốc gia. Mặc dù theo loại hình sử dụng đất có sở hữu công và sở hữu tư, nhưng với mục tiêu đảm bảo quyền tự chủ và tài sản quốc gia, quyền Các-bon chỉ thuộc về nhà nước. Các bên ngoài nhà nước có quyền hưởng lợi từ việc bán cây đứng, quyền sử dụng lâm sản, quyền chuyển giao các tài sản liên quan đến gỗ và dịch vụ môi trường nhưng không có quyền sở hữu hoặc chuyển giao quyền Các-bon. Nói cách khác, quyền Các-bon được tách ra khỏi các quyền hưởng lợi hiện nay của các chủ rừng này. Tuy nhiên, Nhà nước có thể kí chuyển nhượng quyền cho các bên có liên quan. Các kết quả nghiên cứu từ báo cáo này cho thấy trong trường hợp quyền các-bon thuộc về quốc gia, các quốc gia sẽ phê chuẩn cho một Bộ ngành cụ thể (Bộ Tài Chính - nơi quản lí dòng tài chính liên quan đến thương mại phát thải; hoặc Bộ Ngoại Giao - đơn vị quy định hướng dẫn các hoạt động đối với quốc tế - hoặc Bộ Môi trường/Bộ Nông Lâm Nghiệp chịu trách nhiệm hướng dẫn điều phối các hoạt động kĩ thuật giảm phát thải). Việc lựa chọn Bộ ngành nào chịu trách nhiệm phụ thuộc rất nhiêu vào chức năng nhiệm vụ được giao của mỗi Bộ, cũng như năng lực và sức mạnh ảnh hưởng của các bên này trong quá trình đàm phán.

- Mô hình chia sẻ lợi ích. Cơ chế chia sẻ lợi ích đóng vai trò quan trọng trong việc quyết định quyền các-bon thuộc về ai. Có 3 phương án chính liên quan đến hệ thống chia sẻ lợi ích và chuyển quyền Các-bon mà các quốc gia đang áp dụng: i) cơ chế chia sẻ lợi ích ở quy mô quốc gia- trong đó Chính quyền trung ương (đại diện bởi một Bộ hoặc cơ quan nhà nước cụ thể) là nơi toàn quyền điều phối và phân bổ lợi ích tới các bên hưởng lợi; (ii) cơ chế chia sẻ lợi ích theo quy mô quốc gia nhưng được thực hiện và đóng góp bởi chính quyền cấp địa phương kết hợp với các chương trình dự án; (iii) cơ chế chia sẻ lợi ích theo mô hình dự án và chương trình. Đối với trường hợp (ii) và (iii) nhà nước sẽ phải làm rõ quá trình chuyển quyền Các-bon.

Kết quả nghiên cứu cho thấy phần lớn các quốc gia chọn giải pháp gắn liền quyền Các-bon với quyền tự chủ và tài sản quốc gia và được quản lí bởi một cơ quan nhà nước. Việc ai sở hữu quyền Các-bon cũng gắn kết chặt chẽ và vận hành theo cơ chế chia sẻ lợi ích từ việc giảm phát thải. Tuy nhiên, để vận hành cơ chế này tại Việt Nam cần xem xét đến quy phạm pháp luật, năng lực kĩ thuật và tài chính cũng như các chi phí thực hiện để có hướng đi phù hợp. 


\section{Mở đầu}

Giảm phát thải khí nhà kính từ phá rừng và suy thoái rừng $(\mathrm{REDD}+)$ được cộng đông quốc tế và nhiều quốc gia đánh giá là chiến lược quan trọng và hiệu quả trong cuộc chiến chống biến đổi khí hậu. Để hỗ trợ công tác bảo vệ rừng cũng như tạo ra cơ chế tài chính bển vững cho các hoạt động giảm phát thải từ việc phá rừng và suy thoái rừng, nhiều sáng kiến quốc tế đã được thiết lập trong đó nổi bật cả về quy mô và tầm ảnh hưởng là chương trình Chi trả dựa vào kết quả của Quỹ Các-bon, Quỹ Khí Hậu Xanh (GCF), và các thỏa thuận song phương và đa phương giữa các nhà tài trợ và các quốc gia đang phát triển. Chi trả dựa vào kết quả đối với các dự án giảm phát thải nói chung và với các dự án REDD+ nói riêng đã được đề xuất từ năm 2009 và đã có sự cải thiện đáng kể về hệ thống theo dõi, giám sát, thẩm định và đánh giá kết quả làm tiền đề cho chi trả trong 11 năm qua. Tuy nhiên, cho tới nay một thách thức lớn cho các quốc gia trong việc thực hiện các chương trình giảm phát thải là xác định quyền và hệ thống chuyển nhượng quyền các-bon/ giấy chứng nhận giảm phát thải.

Dựa trên tài liệu thứ cấp, báo cáo này được tiến hành bởi Tổ chức Nghiên cứu Lâm nghiệp Quốc tế (CIFOR) nhằm rà soát:

- Sự vận hành và định hướng của thị trường Các-bon quốc tế và nội địa trên toàn câuu

- Các quy định quốc tế có liên quan đến quyền Các-bon và chuyển nhượng kết quả giảm phát thải

- Kinh nghiệm của 87 quốc gia trong việc xác định, xây dựng chính sách liên quan đến quyền Các-bon và chuyển nhượng quyền Các-bon

Báo cáo kì vọng sẽ cung cấp các thông tin đầu vào cho quá trình xây dựng chính sách liên quan đến chuyển quyền Các-bon và chia sẻ lợi ích từ các hoạt động giảm phát thải. 


\section{Phương pháp và phạm vi nghiên cứu}

Báo cáo này được xây dựng dựa trên nghiên cứu và rà soát tài liệu thứ cấp. Nhóm nghiên cứu rà soát các khung chính sách có liên quan của quốc tế cũng như tại 87 quốc gia (Bảng 1).
Ngoài ra, nhóm nghiên cứu cũng rà soát các tài liệu dự án mà các nước đã đệ trình và được thông qua bởi Quỹ Các-bon và GCF cho tới ngày 26 tháng 2 năm 2021 cũng như các nghiên cứu khoa học rà soát lại kinh nghiệm quốc tế liên quan đến lĩnh vực này.

\section{Bảng 1. Số lượng các nước được khảo sát}

\begin{tabular}{lc}
\hline & Tổng số nước \\
\hline Quốc gia tham gia Quỹ Đối tác Các-bon trong Lâm nghiệp (FCPF) & 47 \\
Quốc gia đã nhận được chi trả dựa vào kết quả của Quỹ khí hậu xanh (GCF) & 6 \\
Quốc gia đang thực hiện các cơ chế chi trả giảm phát thải khác nhau (Chương trình dự & 42 \\
án đầu tư bởi khối tư nhân, thỏa thuận song phương giữa các nhà tài trợ và quốc gia \\
phát triển), và các quốc gia OECD và G20 \\
Tổng số
\end{tabular}

a Do có nhiều nước cùng một lúc tham gia nhiều hình thức hợp đồng thương mại phát thải và nhận được nhiều mô hình chi trả dựa vào kết quả nên tổng số thực tế các nước nhóm nghiên cứu chỉ là 87 nước. Ngoài ra, mặc dù rà soát 87 quốc gia không phải quốc gia nào cũng có chính sách cụ thể do vậy nhóm nghiên cứu chỉ tập trung vào những nước đã có cơ chế chính sách hoàn thiện. 


\section{Tổng quan về thị trường Các-bon}

Các cơ chế chi trả cho giảm phát thải từ phá rừng và suy thoái rừng dựa vào kết quả hiện nay được xây dựng đáp ứng 2 mục tiêu khác nhau:

- Hướng tới mục tiêu dài hạn là tạo ra thị trường tiềm năng mới - những chương trình này yêu câu tạo ra các đơn vị giảm phát thải có thể được bán và mua (ví dụ Quỹ Các-bon)

- Mục tiêu ngắn hạn (thí điểm khái niệm chi trả dựa vào kết quả) - những chương trình được đâu tư từ tài chính công và không yêu câuu truy xuất nguồn gốc của từng hoạt động phát thải (Ví dụ Thỏa thuận song phương tài trợ của $\mathrm{Na}$ Uy với Guyana).

Để thực hiện được mục tiêu này, có nhiều loại hình thị trường đã được tạo ra. Các thị trường này khác nhau ở quy mô hoạt động (thị trường Các-bon quốc tế và thị trường Các-bon nội địa); phạm vi hoạt động (thị trường bắt buộc và thị trường tự nguyện), các hàng hóa giao dịch trong thị trường (hạn mức phát thải và bôi hoàn tín chỉ Các-bon), và phương thức định giá Các-bon. Báo cáo sẽ lần lượt trình bày từng khía cạnh trong các phân dưới đây.

\subsection{Thị trường Các-bon quốc tế và Thị trường Các-bon nội địa}

\subsubsection{Thị trường Các-bon quốc tế}

Thỏa thuận Paris có tác động lớn tới việc sử dụng thị trường quốc tế để đáp ứng các mục tiêu bảo vệ môi trường và giảm phát thải trên quy mô toàn cầu. Đặc biệt là Điều khoản 6 của thỏa thuận Paris đã cho phép các quốc gia được sử dụng cơ chế thương mại quốc tế để trao đổi và mua bán hạn mức phát thải để thực hiện các mục tiêu cam kết tự nguyện quốc gia (NDC). Bảng 2 giới thiệu một số cơ chế thị trường giảm phát thải quốc tế mà các nhiều quốc gia trên thế giới đang quan tâm và áp dụng.
Ở cấp độ quốc tế, thị trường Các-bon toàn câuu đã trở thành một nguôn tài chính mới quan trọng cho các dự án và chương trình giảm thiểu. Tuy nhiên, cho đến nay, sự tham gia của chính quyền đô thị và các dự án giảm phát thải từ lâm nghiệp đô thị vào thị trường Các-bon toàn cầu vẫn còn rất hạn chế. Điêu này vừa tạo ra thị trường mới nhửng cũng gây khó khăn trong việc thực hiện các dự án giảm phát thải từ đô thị và tiếp cận thị trường Các-bon (Clapp và cộng sự 2010).

\subsubsection{Thị trường nội địa}

Hiện nay nhiều quốc gia đang hướng tới việc xây dựng thị trường Các-bon nội địa nhằm mục tiêu giảm khí phát thải cũng như phát triển bền vững. Phương thức thiết kế và vận hành các thị trường Các-bon nội địa này rất đa dạng (Hộp 1).

Theo khuyến cáo của Interpol (2013), khi quốc gia tham gia vào thị trường Các-bon quốc tế và thiết lập thị trường Các-bon nội địa cũng cân phải xem xét các rủi ro tội phạm dưới đây:

1. Thao túng gian lận trong phương thức tính toán Các-bon từ đó yêu cầu chi trả tín chỉ Các-bon nhiều hơn so với thực tế thu được;

2. Bán tín chỉ Các-bon không tôn tại hoặc thuộc về người khác;

3. Tuyên bố sai hoặc gây hiểu lầm về lợi ích môi trường hoặc tài chính của các khoản đâu tư vào thị trường Các-bon;

4. Lợi dụng các quy định yếu kém trên thị trường Các-bon để phạm tội tài chính, chẳng hạn như rửa tiền, gian lận chứng khoán hoặc gian lận thuế; và

5. Hack máy tính / lừa đảo để lấy cắp tín chỉ Các-bon và đánh cắp thông tin cá nhân. 


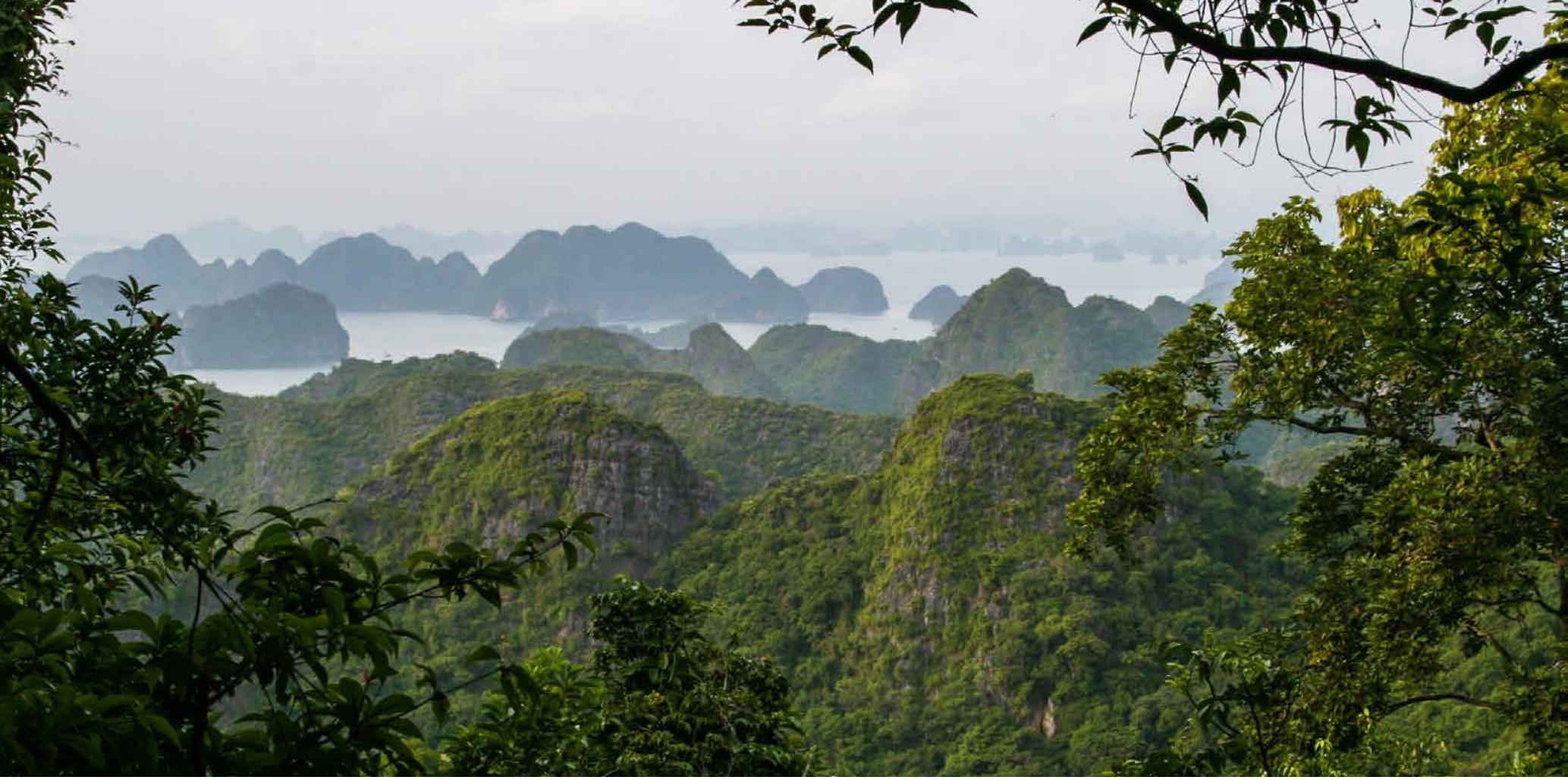

Khung cảnh vịnh Hạ Long nhìn từ đất liền Việt Nam. Ảnh chụp bởi Terry Sunderland/CIFOR

Bảng 2. Các cơ chế giảm phát thải quốc tế

\begin{tabular}{|c|c|}
\hline Cơ chế & Nội dung chi tiết \\
\hline \multirow[t]{2}{*}{$\begin{array}{l}\text { Nghị định } \\
\text { thư Kyoto }\end{array}$} & $\begin{array}{l}\text { - Các quốc gia tham gia ký kết phải chấp nhận việc cắt giảm khí } \mathrm{CO}_{2} \text { và năm loại khí gây hiệu } \\
\text { ứng nhà kính khác, hoặc có thể tiến hành biện pháp thay thế như mua bán phát thải nếu } \\
\text { không muốn đáp ứng yêu cầu đó. }\end{array}$ \\
\hline & $\begin{array}{l}\text { - Các quốc gia được chia làm hai nhóm: nhóm các nước phát triển - còn gọi là nhóm Phụ } \\
\text { lục I (vốn sẽ phải tuân theo các cam kết nhằm cắt giảm khí gây hiệu ứng nhà kính) và } \\
\text { buộc phải có bản đệ trình thường niên về các hành động cắt giảm khí thải; và nhóm các } \\
\text { nước đang phát triển - hay nhóm các nước nằm ngoài Phụ lục I (không chịu ràng buộc các } \\
\text { nguyên tắc ứng xử như Phụ lục I nhưng có thể tham gia vào Cơ chế phát triển sạch). Các } \\
\text { quốc gia thuộc Phụ lục I không đáp ứng được yêu cẩu đặt ra như trong bản ký kết sẽ phải } \\
\text { cắt giảm thêm một phần ba lượng khí vượt mức cho phép trong thời hạn hiệu lực tiếp } \\
\text { theo của Nghị định thư. }\end{array}$ \\
\hline
\end{tabular}

- Kể từ tháng 1 năm 2008 đến hết năm 2012, nhóm nước Phụ lục I phải cắt giảm lượng khí thải để thấp hơn 5\% lượng khí vào năm 1999.

- Cho phép một vài cách tiếp cận linh hoạt cho các nước Phụ lục I nhằm đạt được mục tiêu cắt giảm khí thải bằng cách cho phép các nước này mua lượng khí cắt giảm được từ những quốc gia khác. Điều này có thể đạt được dưới hình thức tài chính hay từ những chương trình hỗ trợ công nghệ cho các nước nằm ngoài Phụ lục I (vốn có tham gia vào Cơ chế phát triển sạch - $\mathrm{CDM}$ ) để các nước này hoàn thành mục tiêu đã ký kết trong Nghị định thư, trong đó chỉ có những thành viên được chứng nhận CER trong CDM mới được phép tham gia. Trong thực tế, điều này có nghĩa là các nền kinh tế nhóm nước đang phát triển tham gia Kyōto Protocol không bị bắt buộc phải giới hạn lượng khí thải gây ra, nhưng một khi chương trình cắt giảm khí thải được xúc tiến ở các quốc gia này họ sẽ nhận được một lượng hạn ngạch các-bon cho phép, vốn có thể bán cho các nước Phụ lục I.

- Các mục tiêu phát thải định lượng cho các nước công nghiệp phát triển và các nước có nền kinh tế đang chuyển đổi (được gọi là các Bên của Phụ lục B) dưới dạng một giới hạn phát thải tuyệt đối cho mỗi bên trong giai đoạn cam kết 2008-2012.

- Các phát thải được phép của mỗi bên trong Phụ lục $B$ được gọi là đơn vị lượng được ấn định $(A A U)$, theo đó một $A A U$ tương đương với một tấn Các-bon dioxide tương đương. Các quốc gia được phép sử dụng $A A U$ từ các Bên trong Phụ lục $B$ khác nhau để tuân thủ, cũng như các đơn vị Kyoto khác, tức là các đơn vị giảm phát thải được chứng nhận (CER), đơn vị giảm phát thải (ERU) và đơn vị loại bỏ (RMU). 
Bảng 2. Tiếp trang trước

\begin{tabular}{|c|c|}
\hline Cơ chế & Nội dung chi tiết \\
\hline $\begin{array}{l}\text { Hiệp định } \\
\text { Marrakech } \\
2001\end{array}$ & $\begin{array}{l}\text { Xác nhận khả năng thay thế của các đơn vị Kyoto khác nhau nhằm mục đích tuân thủ các cam } \\
\text { kết giảm phát thải của các Bên trong Phụ lục B. Nói cách khác, mọi AAU hay CER, ERU và RMU, } \\
\text { bất kể nguồn gốc của nó, đều được coi là tương đương cho các mục đích tuân thủ theo Nghị } \\
\text { định thư Kyoto và có thể bù đắp một tấn Các-bon dioxide tương đương từ bất kỳ lượng phát } \\
\text { thải nào của Bên phụ lục B. }\end{array}$ \\
\hline \multirow{5}{*}{$\begin{array}{l}\text { Cơ chế } \\
\text { thương mại } \\
\text { phát thải của } \\
\text { EU (EU-ETS) }\end{array}$} & $\begin{array}{l}\text { - Việc tuân thủ được yêu cầu hàng năm nhưng việc phân bổ hạn mức phát thải sẽ được quyết } \\
\text { định riêng cho các khoảng thời gian khác nhau. }\end{array}$ \\
\hline & $\begin{array}{l}\text { - Các quốc gia sẽ không tham gia trực tiếp vào cơ chế thương mại giảm phát thải quốc tế } \\
\text { như được quy định trong Kyoto Protoco. }\end{array}$ \\
\hline & $\begin{array}{l}\text { - Các hạn mức sẽ được các quốc gia thành viên trao đổi với nhau, và tương đương một đổi } \\
\text { một với các đơn vị Kyoto. Điều này cho phép EU sử dụng một định nghĩa chung về giảm } \\
\text { phát thải trong khối EU nhưng đảm bảo cho chương trình này khác biệt với hoạt động } \\
\text { thương mại khí thải quốc tế khác. }\end{array}$ \\
\hline & $\begin{array}{l}\text { - Cho phép các bên được đưa vào chương trình và chuyển đổi sang các khoản phụ cấp của } \\
\text { EU theo một số điều kiện nhất định, đặc biệt là từ các dự án Jl và CDM, và từ các chương } \\
\text { trình thương mại nội địa được liên kết. }\end{array}$ \\
\hline & $\begin{array}{l}\text { - Không đề cập đến đơn vị số lượng được ấn định của Kyoto (AAU), ngụ ý rằng các thực thể } \\
\text { trong EU-ETS sẽ không thể mua AAU trực tiếp để bù đắp lượng khí thải gây ra của họ. }\end{array}$ \\
\hline
\end{tabular}

\section{CORSIA}

(Chương trình bù đắp và giảm thiểu Các-bon cho hàng không quốc tế)
Tổ chức Hàng không Dân dụng Quốc tế (ICAO) năm 2016 đã thông qua CORSIA, tạo tiền đề cho một cơ chế dựa trên thị trường toàn cầu để bù đắp và giảm thiểu Các-bon trong lĩnh vực hàng không. CORSIA kì vọng sẽ đạt được mức tăng trưởng trung hòa Các-bon trong ngành hàng không từ năm 2020 trở đi, với mức phát thải trung bình của năm 2019 và 2020 ban đầu được thiết kế để làm đường cơ sở. Do những tác động tiêu cực của Covid-19 đối với hoạt động kinh tế trong ngành hàng không vào năm 2020, Hội đồng ICAO năm 2020 đã đồng ý thực hiện điều chỉnh cho giai đoạn thí điểm 2021-2023 của CORSIA, theo đó đường cơ sở phát thải sẽ được tính toán bằng cách sử dụng chỉ số phát thải năm 2019, thay vì mức phát thải trung bình của năm 2019 và 2020. Để xác định các chuyến bay thuộc chương trình CORSIA, ICAO đã áp dụng cách tiếp cận dựa trên tuyến đường. Một tuyến đường nằm trong chương trình chỉ khi cả hai quốc gia kết nối tuyến đường đều tham gia vào chương trình. Do đó, các hãng hàng không có trụ sở tại các quốc gia không tình nguyện tham gia theo chương trình CORSIA nhưng khai thác các chuyến bay tự do giữa các quốc gia tình nguyện sẽ vẫn phải tuân theo các yêu cầu của CORSIA. Tính tới tháng 7 năm 2020, 88 quốc gia chiếm $88 \%$ các hoạt động hàng không đã cam kết tham gia vào CORSIA. Đây cũng là thị trường quốc tế được kì vọng nhất trong vài thập kỉ tới.

Mặc dù CORSIA là một thị trường quốc tế và không có yêu cầu nào đối với các hãng hàng không phải mua tín dụng nội địa từ quốc gia đăng ký của họ, nhưng nhiều hãng hàng không đã thể hiện sự quan tâm đến việc tìm kiếm các khoản bù đắp từ quốc gia nội địa. Điều này có nghĩa, các quốc gia nên khuyến khích các hãng hàng không của họ tìm nguồn bù đắp tại chính quốc gia và địa phương của mình. Ngoài ra các hãng hàng không hoạt động mạnh ở khu vực nào thì có thể đẩy mạnh khả năng tiếp thị của khu vực đó. Dự báo dựa vào tăng trưởng hoạt động hàng không quốc tế trước COVID cho thấy, CORSIA sẽ tạo ra nhu câuu khoảng 2.5 tỷ $\mathrm{tCO}_{2}$ trong các khoản tín dụng bù đắp từ năm 2021 đến 2035. Tuy nhiên con số này có thể thay đổi dưới tác động của Covid-19, hay việc sử dụng dầu diesel sinh học, và việc áp dụng đầy đủ các công nghệ mới trong lĩnh vực hàng không.

Điểm đáng lưu ý là không phải tiêu chuẩn và dạng dựán nào cũng đủ điều kiện để thuộc cơ chế CORSIA. Tháng 3 năm 2020, ICAO chỉ thông qua 6 tiêu chuẩn và chương trình có thể cung cấp các đơn vị giảm phát thải trong chương trình CORSIA trong thời gian thí điểm bao gồm: (i) Hệ thống đăng kí Các-bon Mỹ; (ii) Chương trình giảm phát thải khí nhà kính tự nguyện của Trung Quốc; (iii) Cơ chế phát triển sạch (CDM); (iv) Chính sách Giữ gìn Môi trường, (v) Tiêu chuẩn vàng, và (vi) Tiêu chuẩn Các-bon có thẩm định. 


\section{Hộp 1. Một số thị trường các-bon nội địa trên thế giới}

Thị trường Các-bon nội địa của Trung Quốc. Hai sáng kiến dựa trên thị trường chính để hỗ trợ xây dựng năng lực của Trung Quốc trong việc thực hiện và thiết kế thị trường Các-bon nội địa là:

- Chương trình Tiêu chuẩn Panda: Tiêu chuẩn Các-bon tự nguyện đầu tiên cho các dự án nội địa của Trung Quốc tập trung vào nông nghiệp và lâm nghiệp. Giá bán một tín chỉ Các-bon là 9.14 USD/tấn, cao hơn giá Các-bon hiện được bán trên thị trường Các-bon tự nguyện nhưng thấp hơn so với định giá mà UNFCCC yêu cầu. Để có thể giao dịch trên thị trường và nhận chi trả, các bên phải đáp ứng các tiêu chuẩn đề ra. Tiêu chuẩn Panda đã được vào hoạt động từ năm 2009 dưới sự hỗ trợ và quản lí của:

- Sàn giao dịch Môi trường Bắc Kinh Trung Quốc (CBEEX) với sự chấp thuận của chính quyền thành phố Bắc Kinh trong việc tạo một nền tảng thị trường chuyên nghiệp cho giao dịch chứng khoán môi trường khác nhau

BlueNext SA, một sàn giao dịch môi trường hàng đầu được thành lập vào năm 2007 bởi NYSE Euronext và Caisse des Depots, đã hợp tác với $C B E E X$ để thiết lập một nền tảng quốc tế nhằm xúc tiến đầu tư vào các dự án CDM ở Trung Quốc và thành lập Tiêu chuẩn Panda

- Sàn giao dịch Lâm nghiệp Trung Quốc (CFEX), được thành lập với sự chấp thuận của Hội đồng nhà nước, Cục Quản lý Lâm nghiệp và Chính quyền thành phố Bắc Kinh. CFEX là một nền tảng thị trường chuyên nghiệp có quy mô toàn quốc và quốc tế nhằm tiến hành kinh doanh thương mại liên quan đến rừng Winrock International phát triển các tiêu chuẩn giám sát và đo lường Các-bon

Cơ quan đăng ký Các-bon Hoa Kỳ ( $A C R)$ là cơ quan đăng ký bù đắp KNK tự nguyện đầu tiên ở Hoa Kỳ Ngân hàng Phát triển Châu Á (ADB)

- Chương trình thương mại phát thải do chính quyền thành phố An Tân tạo ra áp dụng với các nhà cung cấp nhiệt trong tòa nhà dân cư. Thị trường này do Sở giao dịch khí hậu Thiên Tân (TCX) điều hành.

Thị trường Các-bon nội địa của US. Có nhiều mô hình xây dựng thị trường Các-bon bắt buộc nội địa của Mỹ như các sáng kiến về khí nhà kính trong khu vực (RGGl, 2009), Sáng kiến Khí hậu Phương Tây (WCl, 2012) (Xin xem các phần dưới đây để biết thêm thông tin chi tiết).

Thị trường Các-bon nội địa của UK. UK sẽ tham gia cơ chế thương mại phát thải của EU (EU-ETS) nhưng dự kiến sẽ đưa thị trường Các-bon nội địa và thuế Các-bon đi vào hoạt động trong năm 2021. Khi định giá Các-bon của UK, chính phủ đã xem xét 3 giải pháp: kết nối với EU-ETS, xây dựng một hệ thống UK-ETS riêng hoặc thuế phát thải Các-bon. Cuối cùng chính phủ đã quyết định xây dựng hệ thống thương mại của UK (UK-ETS) riêng biệt. UK cũng tính đến giải pháp hài hòa với EU-ETS nhưng trong trường hợp không hài hòa được thì UK sẽ đề xuất một cơ chế định giá Các-bon khác, ví dụ cho bán đấu giá với định giá tối thiểu. Cùng lúc đó UK dự định sẽ đánh thuế GBP18/ mt $\mathrm{CO}_{2}$ trong năm tài chính 2021-2022. Cơ chế này sẽ giúp UK tiến tới một "cuộc cách mạng xanh" vì đây là "thị trường thương mại và giới hạn các-bon ròng đầu tiên trên thế giới". Đề án này tham vọng hơn so với hệ thống của EU mà nó thay thế; kể từ ngày đầu tiên, giới hạn phát thải được phép trong hệ thống sẽ giảm $5 \%$. Điều này mang lại cho các ngành sự chắc chắn cần thiết để đầu tư vào công nghệ Các-bon thấp. Kế hoạch của Vương quốc Anh sẽ yêu cầu giảm 68\% lượng khí thải $\mathrm{CO}_{2}$ vào năm 2030 so với mức cơ sở năm 1990, so với cam kết $55 \%$ của Ủy ban châu Âu, được công bố vào đầu tháng 12 năm 2020. Chương trình sẽ được thực hiện với các khí thải từ hàng loạt ngành công nghiệp sử dụng nhiều năng lượng, sản xuất điện và hàng không. Tuy nhiên quốc gia này sẽ tìm kiếm các cơ hội để mở rộng ETS của Vương quốc Anh nhằm bao phủ 2/3 lượng khí thải chưa được kiểm soát.

Thị trường Các-bon nội địa của Pháp. Chính phủ sẽ ban hành đơn vị giảm phát thải (ERU) cho các nhà phát triển dự án giảm phát thải ở Pháp. Các ERU có thể được công ty sử dụng để tuân thủ với cơ chế EU ETS. Để tạo điều kiện thuận lợi cho các dự án, chính phủ đang dự định gắn nhãn tám tiêu chuẩn cho các loại dự án khác nhau. Cơ chế này bao gồm hầu hết các phát thải $\mathrm{CO}_{2}$ liên quan đến năng lượng, các khoản tín chỉ bồi hoàn Các-bon ưu tiên dành cho nội địa. Với quan điểm gánh nặng của chính sách về biến đổi khí hậu không chỉ nên đặt lên vai của riêng ngành công nghiệp nặng, chính phủ cũng đã xem xét tới khả năng giá Các-bon sẽ được chuyển cho người tiêu dùng các sản phẩm năng lượng. 


\subsection{Thi trường Các-bon bắt buộc và Thị trường Các-bon tự nguyện}

Các quốc gia và các dự án có quyên lựa chọn đi theo thị trường Các-bon hoặc thị trường tự nguyện hoặc cả hai lựa chọn.

\subsubsection{Thị trường bắt buộc}

Thị trường Các-bon bắt buộc được tạo ra cho các bên theo luật định có nghĩa vụ phải giảm phát thải. Bảng 3 trình bày một số cơ chế thị trường Các-bon bắt buộc đang vận hành trên toàn câuu.

Bảng 3. Một số cơ chế thị trường Các-bon bắt buộc phổ biến

\begin{tabular}{|c|c|c|c|}
\hline Tên & Các bên tham gia & Cơ chế hoạt động & $\begin{array}{l}\text { Phạt và giá hạn } \\
\text { mức cho phép }\end{array}$ \\
\hline $\begin{array}{l}\text { Chương trình } \\
\text { loại bỏ khí nhà } \\
\text { kính của bang } \\
\text { New South } \\
\text { Wales, Australia }\end{array}$ & $\begin{array}{l}\text { Ngành điện, người bán } \\
\text { điện, người sử dụng } \\
\text { điện > 100Gw/a có thể } \\
\text { tự nguyện quản lí hạn } \\
\text { mức khí phát thải của } \\
\text { mình }\end{array}$ & $\begin{array}{l}\text { Chính phủ quy định hạn mức phát thải hàng năm } \\
\text { cho ngành điện. Hạn mức này buộc các bên tham } \\
\text { gia sản xuất điện phải thực hiện giảm phát thải } \\
\text { dựa trên đóng góp vào sản lượng điện hiện nay. } \\
\text { Để chứng minh các bên đã thực hiện đúng quy } \\
\text { định, doanh nghiệp phải nộp giấy chứng nhận đã } \\
\text { giảm phát thải từ các dự án giảm phát thải }\end{array}$ & $\begin{array}{l}\text { AUD } 11.50 \text { vào } \\
\text { năm } 2006 \text {. Cho } \\
\text { phép mức đạt } \\
\text { được dưới } 10 \% \text { dự } \\
\text { tính nhưng phải } \\
\text { trả lại và bù lại } \\
\text { vào năm sau }\end{array}$ \\
\hline $\begin{array}{l}\text { Chương trình } \\
\text { thương mại } \\
\text { phát thải của } \\
\text { Na Uy }\end{array}$ & $\begin{array}{l}\text { Ngành năng lượng, } \\
\text { dầu, khoáng sản, sản } \\
\text { xuất nước giải khát, } \\
\text { ngành sản xuất sắt, } \\
\text { thép, ngành xi măng, } \\
\text { thủy tinh, đá và các } \\
\text { sản phẩm sành sứ, sản } \\
\text { xuất dầu mỏ ngoài Na } \\
\text { Uy, ngành sản xuất } \\
\text { phân bón }\end{array}$ & $\begin{array}{l}\text { - Không tính hạn mức từ 2005-2007, dựa trên } \\
\text { đường phát thải cơ bản giai đoạn 1998-2001, } \\
\text { nhưng từ năm } 2001 \text { sẽ được phân bố dựa trên } \\
\text { dự đoán, bao gồm cả dự báo về tiềm năng ứng } \\
\text { dụng công nghệ và tiêm năng kinh tế có thể } \\
\text { giảm phát thải } \\
\text { - Không có định mức dành cho đấu giá giai } \\
\text { đoạn } 2008-2012 \\
\text { - Các ngành công nghiệp sử dụng đất sẽ được } \\
\text { phân bổ dựa trên lịch sử phát thải giai đoạn } \\
\text { 2008-2012 } \\
\text { - Các bên khai thác dầu mỏ nước ngoài sẽ được } \\
\text { tham gia vào cơ chế này nhưng không được } \\
\text { hưởng hạn ngạnh miễn phí. Thuế CO } 2 \text { cũng sẽ } \\
\text { được điều chỉnh } \\
\text { - Không cấp hạn mức cho các doanh nghiệp } \\
\text { mới trừ khi chứng minh được là các doanh } \\
\text { nghiệp này rất hiệu quả trong việc không } \\
\text { gây phát thải } \\
\text { - Trong giai đoạn giao dịch thứ hai, } 90 \% \text { hạn } \\
\text { mức sẽ được tính miễn phí. Đấu giá đóng vai } \\
\text { trò lớn trong việc phân bổ hạn mức (> 50\%). } \\
\text { Các ngành công nghiệp ngoài khơi sẽ chiếm } \\
\text { hơn một nửa lượng phát thải được giảm }\end{array}$ & $\begin{array}{l}\text { 40EURO/tCO } 2 \text { bị } \\
\text { thiếu trong mối } \\
\text { hạn mức cho } \\
\text { phép (tương ứng } \\
\text { với thuế Các-bon } \\
\text { giai đoạn 2005- } \\
\text { 2007) } \\
\text { 100EURO/tCO } 2 \\
\text { cho mỗi hạn } \\
\text { ngạnh bị thiếu } \\
\text { liên quan đến đến } \\
\text { hạn ngạch sẽ trả } \\
\text { lại trong giai đoạn } \\
\text { mua bán tiếp } \\
\text { theo } \\
\text { Không có giá cho } \\
\text { hạn mức }\end{array}$ \\
\hline $\begin{array}{l}\text { Sáng kiến khí } \\
\text { thải nhà kính } \\
\text { khu vực (RGGI) } \\
\text { của Mỹ }\end{array}$ & $\begin{array}{l}\text { Các bên sản xuất điện, } \\
\text { than, dầu mỏ, khí gas, } \\
\text { máy phát điện }\end{array}$ & $\begin{array}{l}\text { Các Bang của Mỹ kí cam kết tham gia vào sáng } \\
\text { kiến này và mỗi Bang sẽ có cách vận hành riêng. } \\
\text { Tuy nhiên, các Bang sẽ cùng dành } 25 \% \text { hạn mức } \\
\text { phát thải bán được để tái đầu tư và phục vụ cho } \\
\text { lợi ích của người sử dụng (sử dụng năng lượng } \\
\text { hiệu quả, công nghệ sạch) } \\
\text { Các hạn mức giảm phát thải có thể được bán đấu } \\
\text { giá. Sử dụng số tiền thu được từ việc bán hàng } \\
\text { đó để tài trợ cho các chương trình tiết kiệm năng } \\
\text { lượng, giảm nhu cầu, năng lượng tái tạo }\end{array}$ & Chưa quyết định \\
\hline
\end{tabular}


Bảng 3. Tiếp trang trước

\begin{tabular}{|c|c|c|c|}
\hline \multirow[t]{3}{*}{ Tên } & Các bên tham gia & Cơ chế hoạt động & $\begin{array}{l}\text { Phạt và giá hạn } \\
\text { mức cho phép }\end{array}$ \\
\hline & & $\begin{array}{l}\text { Các ngành công nghiệp có ba lựa chọn để đáp } \\
\text { úng mức giảm phát thải: (i) cải thiện cơ sở vật chất } \\
\text { và hoạt động, (ii) mua các tín chỉ hoặc (iii) đóng } \\
\text { góp vào Quỹ Quản lý Khí thải và Biến đổi Khí hậu }\end{array}$ & \\
\hline & & $\begin{array}{l}\text { Quy tắc Mô hình RGGI đã phát triển chi tiết cho } \\
05 \text { hạng mục chung về bù đắp và bồi hoàn tín } \\
\text { chỉ Các-bon trong nước: "(i) Thu giữ và loại bỏ } \\
\text { khí mê-tan ở bãi chôn lấp; (ii) Giảm phát thải lưu } \\
\text { huỳnh hexafluoride (SF6); (iii) hấp thụ và lưu giữ } \\
\text { Các-bon do trồng rừng; (iv) Giảm hoặc tránh phát } \\
\text { thải } \mathrm{CO}_{2} \text { từ quá trình đốt cháy cuối cùng bằng } \\
\text { khí thiên nhiên, dầu hoặc propan do hiệu quả sử } \\
\text { dụng năng lượng cuối [cải tiến]; và (v) Ngăn chặn } \\
\text { phát thải khí mê-tan từ phân bón sử dụng trong } \\
\text { lĩnh vực nông nghiệp" }\end{array}$ & \\
\hline $\begin{array}{l}\text { Cơ chế thương } \\
\text { mại phát } \\
\text { thải của New } \\
\text { Zealand }\end{array}$ & $\begin{array}{l}\text { Ngành lâm nghiệp, } \\
\text { giao thông sử dụng } \\
\text { xăng dầu, nông } \\
\text { nghiệp, lâm nghiệp, } \\
\text { rác thải, sản xuất và } \\
\text { chăn nuôi (chế biến } \\
\text { thịt và sữa) }\end{array}$ & $\begin{array}{l}\text { - Giới hạn phát thải được thiết lập theo Nghị } \\
\text { định thư Kyoto và trong bất kỳ giới hạn nào } \\
\text { được thiết lập theo các thỏa thuận quốc tế sau } \\
\text { năm } 2012 \\
\text { • Chính phủ sẽ thành lập các Đơn vị giảm phát } \\
\text { thải của New Zealand (NZU) và sẽ hỗ trợ tương } \\
\text { đồng đối với các đơn vị Kyoto. NZU sẽ được } \\
\text { chuyển đổi thành các đơn vị ở Kyoto và được } \\
\text { bán ra thị trường quốc tế. Các đơn vị ở Kyoto } \\
\text { có thể được mua ở nước ngoài (tuân theo một } \\
\text { số hạn chế) và được sử dụng để đáp ứng các } \\
\text { nghĩa vụ dưới cơ chế này, cụ thể hơn giảm trừ } \\
\text { một NZU cho mỗi tấn khí thải }\end{array}$ & $\begin{array}{l}\text { Không thực hiện } \\
\text { sẽ bị phạt NZD30/ } \\
\text { tCO } \text {. Nếu cố } \\
\text { tình phạm tội sẽ } \\
\text { bị phạt lên đến } \\
\text { NZD60/tCO và } \\
\text { phải đền gấp } 2 \\
\text { lần so với quy } \\
\text { định. Nếu không } \\
\text { thực hiện cũng có } \\
\text { thể bị vào tù }\end{array}$ \\
\hline
\end{tabular}

Nguồn: Reinaud và Philibert (2007)

\subsubsection{Thị trường Các-bon tự nguyện (VCM)}

Theo Guigon và BlueNext (2010), VCM có những đặc điểm sau:

- Được tạo ra bởi các công ty và cá nhân tự nguyện mua bù đắp Các-bon để giảm phát thải khí nhà kính (KNK) mà họ tạo ra với mục đích xây dựng hình ảnh và dự đoán phải tuân thủ các quy định trong tương lai

- Cung cấp các bộ công cự và nguồn tài chính để giải quyết các vấn đề tôn tại đối với thị trường hiện nay ví dụ như sự chậm trễ trong các thỏa thuận quốc tế, hoặc không được tham gia vào các cơ chế thương mại giao dịch khác

- Các dự án lâm nghiệp có tiềm năng và tiếp cận dễ dàng hơn đối với thị trường VCM, đặc biệt là các dự án liên quan đến trông mới và tái trông rừng, $\mathrm{REDD}+$
- Việc thực hiện và tham gia VCM cũng xây dựng năng lực cho các bên có liên quan trong đó có nhà nước, khối tư nhân và cộng đông dễ dàng thực hiện các thị trường Các-bon bắt buộc trong tương lai

Bảng 4 trình bày ví dụ về thị trường các-bon tự nguyện đang được áp dụng tại Nhật Bản.

Tùy vào yêu cầu của người mua, các bên bán kết quả giảm phát thải sẽ phải đáp ứng các tiêu chuẩn Các-bon tự nguyện mới có thể giao dịch được trên thị trường các-bon tự nguyện. Các tiêu chuẩn Các-bon này được thiết lập nhằm đưa ra quy trình, hướng dẫn và công cụ để phát triển, đánh giá và xác nhận một dự án giảm phát thải. Có rất nhiều tiêu chuẩn hiện có trên thị trường (Bảng 5). 
Bảng 4. Cơ chế thương mại phát thải của Nhật Bản

\begin{tabular}{|c|c|c|c|c|}
\hline Tên & Các bên tham gia & Khí nhà kính trao đổi & $\begin{array}{l}\text { Phương pháp } \\
\text { phân bổ }\end{array}$ & Phạt và giá hạn mức cho phép \\
\hline $\begin{array}{l}\text { Cơ chế } \\
\text { thương mại } \\
\text { phát thải } \\
\text { Nhật Bản }\end{array}$ & $\begin{array}{l}\text { Ngành công } \\
\text { nghiệp đồ ăn, đồ } \\
\text { uống, bột giấy, } \\
\text { hóa chất }\end{array}$ & $\begin{array}{l}\text { Phát thải } \mathrm{CO}_{2} \text { từ việc } \\
\text { sử dụng năng lượng } \\
\text { và chuyển đổi từ dùng } \\
\text { dầu mỏ tới các dạng } \\
\text { xăng dầu khác ít phát } \\
\text { thải hơn }\end{array}$ & $\begin{array}{l}\text { Dựa trên đường } \\
\text { phát thải lịch sử } \\
\text { trừ đi kì vọng } \\
\text { giảm phát thải } \\
\text { của công ty }\end{array}$ & $\begin{array}{l}\text { Không có hình phạt nào nhưng công } \\
\text { ty sẽ phải trả lại trợ cấp tiền mặt mà } \\
\text { chính phủ đang hỗ trợ cho ngành } \\
\text { công nghiệp này nếu không đạt được } \\
\text { mục tiêu để ra. Không có giá thành } \\
\text { cho mối hạn mức phát thải }\end{array}$ \\
\hline
\end{tabular}

Nguồn: Reinaud và Philibert (2007)

Bảng 5. Các tiêu chuẩn Các-bon

\begin{tabular}{|c|c|}
\hline Cơ chế phát triển sạch - CDM & $\begin{array}{l}\text { Là một phần của nghị định thư Kyoto và nhằm tạo ra hiệu quả kinh tế đồng thời } \\
\text { mang lại lợi ích đồng phát triển cho các quốc gia đang phát triển. CDM đã thành } \\
\text { công trong việc tạo ra một số lượng lớn các khoản bổi hoàn tín chỉ Các-bon nhưng } \\
\text { còn chưa rõ có mang lại những đồng lợi ích phát triển như đã hứa hay không }\end{array}$ \\
\hline Tiêu chuẩn Vàng - GS & $\begin{array}{l}\text { Nhằm mục đích nâng cao chất lượng bù đắp Các-bon và tăng đồng lợi ích của } \\
\text { chúng giống như đối với CDM. Tuy nhiên, không giống như CDM, GS cũng yêu cầu } \\
\text { các công cụ cộng hưởng CDM cho các dự án quy mô nhỏ }\end{array}$ \\
\hline $\begin{array}{l}\text { Tiêu chuẩn Các-bon tự nguyện } \\
2007 \text { (VCS 2017) }\end{array}$ & $\begin{array}{l}\text { Hướng tới mục tiêu trở thành một tiêu chuẩn chất lượng cơ bản, phổ biến giảm } \\
\text { gánh nặng hành chính và chi phí. }\end{array}$ \\
\hline VER + & $\begin{array}{l}\text { Cung cấp một cách tiếp cận tương tự với CDM cho các nhà phát triển dự án đã } \\
\text { quen thuộc CDM và bao gồm cả dự án nằm ngoài phạm vi của CDM }\end{array}$ \\
\hline $\begin{array}{l}\text { Thị trường chứng khoán khí } \\
\text { hậu Chicago }\end{array}$ & CCX là công ty tiên phong trong việc thành lập thị trường Các-bon của Hoa Kỳ. \\
\hline $\begin{array}{l}\text { Tiêu chuẩn bồi hoàn Các-bon } \\
\text { tự nguyện (VOS) -. }\end{array}$ & $\begin{array}{l}\text { VOS tuân thủ chặt chẽ các yêu cầu của CDM và nhằm mục đích giảm thiểu rủi ro } \\
\text { cho người mua tín chỉ bôii hoàn Các-bon trên thị trường tự nguyện }\end{array}$ \\
\hline $\begin{array}{l}\text { Các tiêu chuẩn về khí hậu, cộng } \\
\text { đồng và đa dạng sinh học (CCBS) }\end{array}$ & $\begin{array}{l}\text { CCBS nhằm hỗ trợ phát triển bền vững và bảo tồn đa dạng sinh học. CCBS chỉ là } \\
\text { Tiêu chuẩn thiết kế dự án và không xác minh mức giảm phát thải đã định lượng }\end{array}$ \\
\hline Kế hoạch Vivo & $\begin{array}{l}\text { Kế hoạch Vivo đặt mục tiêu cung cấp sinh kế nông thôn bền vững thông qua tài } \\
\text { chính Các-bon. Xác minh của bên thứ ba không bắt buộc }\end{array}$ \\
\hline
\end{tabular}

Nguồn: Kollmuss và cộng sự (2008)

Theo dự báo của South Pole (2020):

- Thị trường Các-bon tự nguyện sẽ tiếp tục tăng trưởng mạnh khi các quốc gia và tập đoàn cân phải tuân thủ Thỏa thuận Paris.

- Sau năm 2020 sẽ rất khó để có thể dự báo về nhu cung câu cho thị trường này bởi nhiều quốc gia đang định xây dựng thị trường Cácbon nội địa cũng như tham gia vào thị trường Các-bon quốc tế.

- Hiện chưa rõ các công ty có được sử dụng tín chỉ Các-bon phát hành bởi các tiêu chuẩn tự nguyện để công bố các cam kết Các-bon trung tính dưới Thỏa thuận Paris không ? Phát thải từ các dự án từ thị trường Các-bon tự nguyện chỉ được tính có một lân bởi quốc gia sở tại.
Ngoài ra, một vài lĩnh vực và ngành sẽ không được tính bởi quốc gia sở tại nếu như lĩnh vực hoạt động này không được đề cập trong NDC

- Thị trường Các-bon tự nguyện và Điều khoản 6 trong Thỏa thuận Paris sẽ cùng hoạt động như thế nào ? Liệu thị trường Các-bon tự nguyện có thể sử dụng cho Điều khoản 6 được không ? Các dự án của thị trường Các-bon tự nguyện sử dụng tiêu chuẩn vàng vẫn có thể cấp đơn vị giảm phát thải đã được thẩm định (VER/ VCUs) như thông thường và các đơn vị này có thể được mua bởi một nước khác để báo cáo về kết quả NDC đạt được của mình. Khi VCUs được chuyển từ dự án sang một quốc gia để báo cáo thì chúng đã trở thành ITMOs. 


\subsection{Hàng hóa giao dịch trong thi trường: hạn mức phát thải và bồi hoàn tín chî Các-bon}

Bảng 6 trình bày hai cơ chế hàng hóa Các-bon khác nhau hiện đang được giao dịch trên các thị trường Các-bon hiện nay.

\section{4 Định giá Các-bon}

Thay vì chỉ định ai nên giảm lượng khí thải ở đâu và bằng cách nào, định giá Các-bon đưa ra một tín hiệu kinh tế và những người gây ô nhiễm sẽ tự quyết định xem có nên ngừng hoạt động gây ô nhiễm của họ, giảm lượng khí thải, hay tiếp tục gây ô nhiễm và trả tiền cho việc tiếp tục phát thải. Bằng cách này, mục tiêu tổng thể về môi trường đạt được một cách linh hoạt nhất và ít tốn kém nhất cho xã hội. Giá Các-bon cũng khuyến khích các bên sử công nghệ sạch và đổi mới thị trường, thúc đẩy tăng trưởng kinh tế Các-bon thấp (World Bank 2014). Hiện đã có 61 sáng kiến định giá Các-bon được đưa ra hoặc được lên kế hoạch thực hiện, bao gồm 31 cơ chế thương mại phát thải và 30 loại thuế Các-bon. Các sáng kiến này có tiềm năng giảm 2 Gigatons Các-bon dioxide tương đương $\left(\mathrm{GtCO}_{2} \mathrm{e}\right)$ hoặc khoảng $22 \%$ lượng phát thải KNK toàn câu (World Bank 2020). Hình 1 và Hình 2 cho thấy tiềm năng của giá trị thị trường Các-bon cũng như giá Các-bon có thể bán được trong thị trường Các-bon tự nguyện.
Tiềm năng của giá trị thị trường Các-bon được dự báo sẽ tăng mạnh trong giai đoạn 2030-2050 khi các quốc gia buộc phải thực hiện đầy đủ các cam kết giảm phát thải của mình (Hình 2).

Trên bình diện quốc tế, các quốc gia công nghiệp như Mỹ, Canada, Nhật Bản và Châu Âu sẽ vẫn là người mua chủ đạo của ITMOs trong khi các nước Châu Mỹ La tin, Trung Quốc và Ấn Độ, Châu Phi là người bán then chốt. Tuy nhiên, một số nước hiện đang là người bán sẽ chuyển sang vai trò là người mua vào cuối thế kỉ này (South Pole 2020).

Tất cả các quốc gia đều muốn tính toán giá thành cho việc giảm phát thải. Tuy nhiên, do chưa có thị trường thực sự và đúng nghĩa cho việc này, nên các tính toán này chỉ có thể đưa ra giá ảo. Giá ảo là giá hoặc giá trị qui đổi của hàng hóa và dịch vụ khi chúng không được xác định một cách chính xác do thiếu thị trường để hình thành giá cả, hoặc do có sự biến động của giá cả trên thị trường. Theo tính toán dựa vào các INDC được nộp từ năm 2015, giá ảo của giảm phát thải là $161 \mathrm{USD} / \mathrm{tCO}_{2}$ cao hơn $50 \%$ so với giá ảo được ước tính trên quy mô toàn câuu vào năm 2100. Sự gia tăng này chứng tỏ rằng, trong cả hai kịch bản, các hoạt động giảm thiểu được thựcc hiện trong giai đoạn đâu 2020-2035 sẽ thể hiện sự tiết kiệm cho các nước bên bán, dẫn đến các hành động giảm phát thải mạnh mẽ hơn (OECD 2016). Ngược lại, đến năm 2050, những

Bảng 6. Sự khác biệt giữa hai cơ chế hàng hóa Các-bon

\begin{tabular}{|c|c|c|}
\hline Đặc điểm chính & Hạn mức phát thải và thương mại & Tín chỉ bồi hoàn Các-bon \\
\hline Hàng hóa trao đổi & $\begin{array}{l}\text { Hạn mức phát thải, trong đó giảm phát thải } \\
\text { không được tạo ra hoặc loại bỏ mà chỉ trao } \\
\text { đổi giữa các bên }\end{array}$ & $\begin{array}{l}\text { Các tín chỉ Các-bon mà người mua có thể tuân } \\
\text { thủ các quy định về phát thải, và đền bù các } \\
\text { hoạt động phát thải (như của hãng máy bay) }\end{array}$ \\
\hline Số lượng có thể bán & Được xác định bởi hạn mức tổng thể & Được tạo ra bởi từng dự án riêng lẻ \\
\hline Thị trường hướng tới & Thị trường bắt buộc & $\begin{array}{l}\text { Cả thị trường bắt buộc và thị trường tự } \\
\text { nguyện }\end{array}$ \\
\hline Cơ cấu thị trường & $\begin{array}{l}\text { Cả người mua và người bán có lợi ích } \\
\text { chung nhưng cũng có thể tranh chấp và } \\
\text { mâu thuẫn trong việc thương mại phát thải }\end{array}$ & $\begin{array}{l}\text { Cả người mua và người bán muốn tối đa hóa } \\
\text { tín chỉ Các-bon và bồi hoàn Các-bon tạo ra từ } \\
\text { dự án }\end{array}$ \\
\hline Nguồn tài chính & $\begin{array}{l}\text { Thông thường là các bên có lượng phát } \\
\text { thải cao như lĩnh vực năng lược và ngành } \\
\text { công nghiệp phát thải cao }\end{array}$ & $\begin{array}{l}\text { Được quy định theo từng tiêu chuẩn và } \\
\text { không chỉ phụ thuộc vào các bên có lượng } \\
\text { phát thải cảo }\end{array}$ \\
\hline $\begin{array}{l}\text { Bên thứ } 3 \text { độc lập } \\
\text { thẩm định }\end{array}$ & $\begin{array}{l}\text { Đóng vai trò không quan trọng trong việc } \\
\text { thẩm định kết quả kiểm kê phát thải }\end{array}$ & $\begin{array}{l}\text { Đóng vai trò chủ chốt trong việc thẩm định } \\
\text { tính chính xác và tính bổ sung của giảm phát } \\
\text { thải được đề xuất }\end{array}$ \\
\hline
\end{tabular}




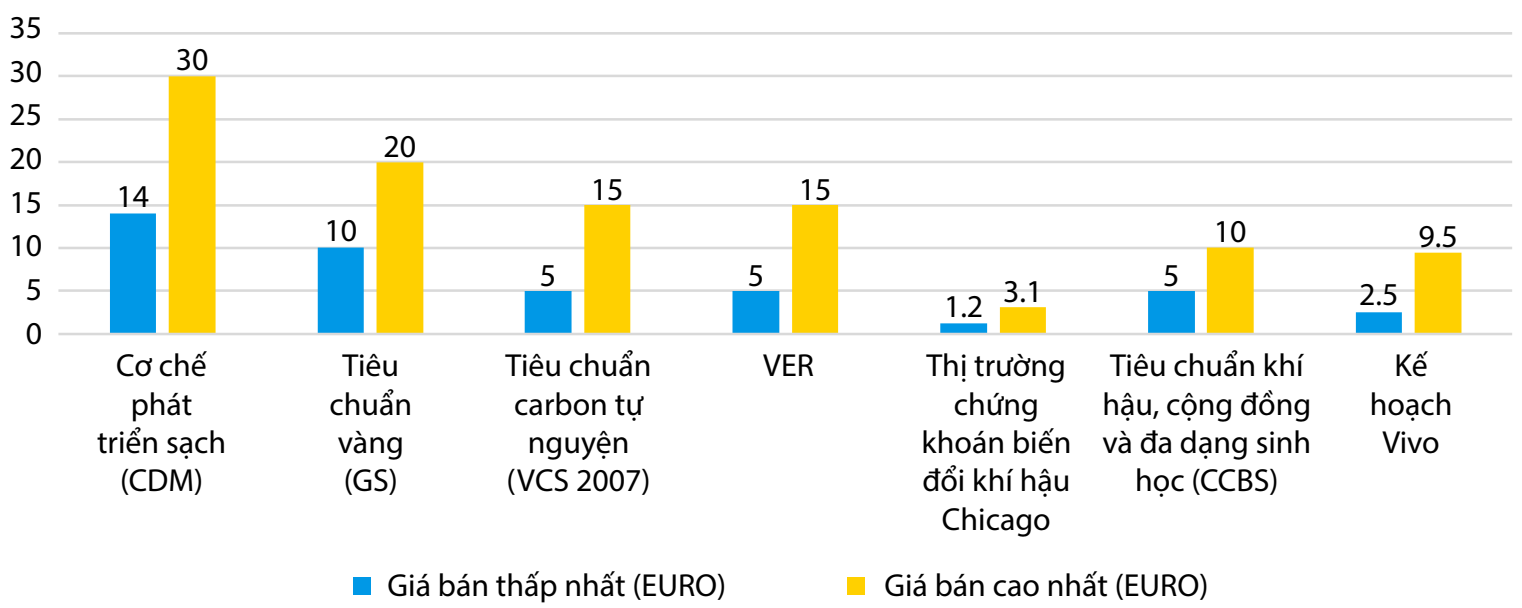

Hình 1. Giá bán Các-bon trên các thị trường Các-bon tự nguyện

Nguồn: Kollmuss và cộng sự (2008)

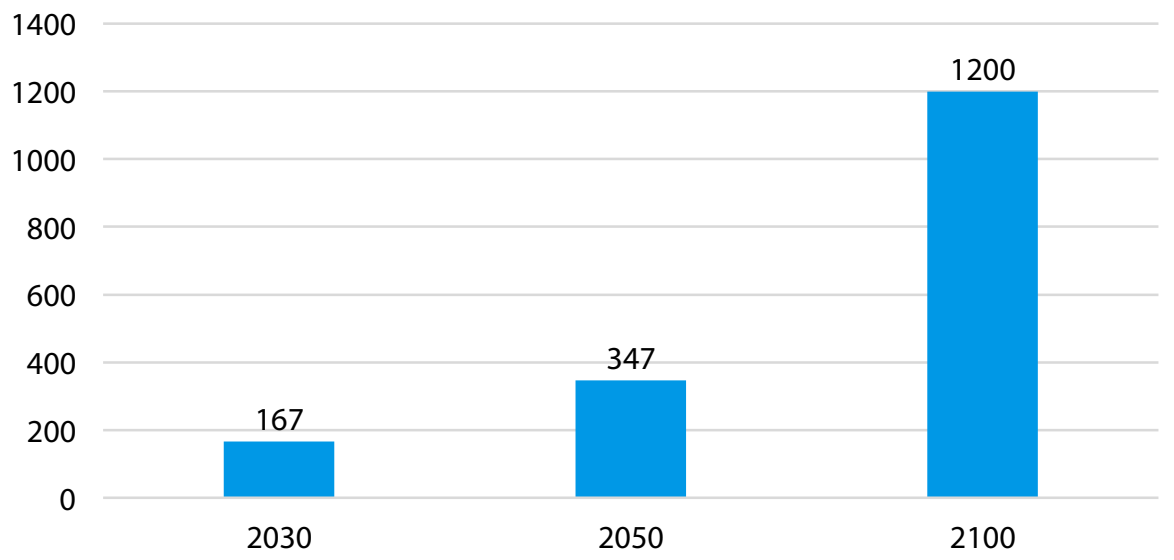

Hình 2. Giá trị của thị trường Các-bon giai đoạn 2030-2050 (Đơn vị: triệu USD) Nguồn: South Pole (2020)

khoản tiết kiệm đó chuyển thành chi phí khi các quốc gia này trở thành người mua ITMO, và do vậy có khả năng hạn chế tham vọng giảm phát thải của họ.

Các quốc gia có cách tiếp cận định giá Các-bon khác nhau, đặc biệt có sự khác nhau giữa xây dựng thuế Các-bon và hệ thống thương mại giảm phát thải. Trong 41 nước $\mathrm{OECD}$ và $\mathrm{G} 20$ chiếm tới $80 \%$ việc sử dụng năng lượng trên toàn câuu và phát thải $\mathrm{CO}_{2}(\mathrm{OECD} 2016)$ thì:

- $60 \%$ lượng khí thải Các-bon từ việc sử dụng năng lượng không được định giá.

- Ngay cả khi Các-bon được định giá, giá có xu hướng thấp. Thiệt hại do biến đổi khí hậu gây ra từ một tấn khí thải $\mathrm{CO}_{2}$ được ước tính tối thiểu là 30 EUR. Tuy nhiên chỉ có $10 \%$ lượng khí thải được định giá ở mức Các-bon hiện nay bằng hoặc vượt quá 30 EUR cho mỗi tấn $\mathrm{CO}_{2}$. Nói cách khác, $90 \%$ lượng khí thải hiện nay đã không được định giá đúng mức.

- Trong các ngành, chỉ có ngành giao thông đường bộ là có định giá Các-bon hiệu quả với trên $46 \%$ phát thải được định giá trên 30 $\mathrm{EUR} /$ tấn $\mathrm{CO}_{2}$ và chỉ có $2 \%$ lượng phát thải là chưa được định giá.

- Thuế xăng dầu có thể thể hiện ô nhiễm không khí và thường trên 30 Euro/tấn $\mathrm{CO}_{2}$.

- Khí thải từ ngành điện được định giá ở nhiều quốc gia, hâu hết ở mức thấp và thường thông qua thuế tiêu thụ, vốn không khuyến khích chuyển sang sử dụng nhiên liệu sạch hơn. Tác động của các hệ thống mua bán khí thải đối với tỷ lệ Các-bon hiệu quả là lớn 
nhất trong ngành công nghiệp và ngành điện. Thuế áp dụng đối với $17 \%$ phát thải trong công nghiệp và $27 \%$ trong điện, và tín hiệu giá từ việc mua bán khí thải làm tăng tỷ lệ này lên $26 \%$ đối với công nghiệp và $36 \%$ đối với điện.

Theo một báo cáo khác, khoảng 85\% lượng khí thải toàn câu cho tới cuối năm 2017 vẫn không được định giá, và $75 \%$ lượng khí thải được tính theo giá Các-bon có giá dưới 10 USD / tấn $\mathrm{CO}_{2}$ $\left(\mathrm{tCO}_{2}\right)$. Mức giá đó là quá thấp, vì theo báo cáo, để đạt mục tiêu cam kết trong thỏa thuận Paris, mức giá Các-bon tối thiếu ít nhất phải là 40-80 $\mathrm{USD} / \mathrm{tCO}$ vào năm 2020 và $50-100 \mathrm{USD} / \mathrm{tCO}_{2}$ vào năm 2030 (Dender 2017). Tuy nhiên, con số tính toán hiện nay chưa tính đến thuế tiêu thụ đặc biệt đối với các loại nhiên liệu giao thông, sưởi ấm và sử dụng năng lượng rộng rãi hơn, hoặc các thuế Các-bon hiện hành (Dender 2017).

Có nhiều cách để chính phủ có thể định giá Cácbon, ví dụ xác định các chi phí liên quan đến việc phát thải Các-bon, chi phí mà người dân phải trả ví dụ như tổn hại đến mùa màng và chữa bệnh và dựa vào đó tính toán giá Các-bon. Tuy nhiên, hiện có hai hình thức định giá Các-bon chính được nhiều quốc gia áp dụng: hệ thống giao dịch khí thải (ETS) và thuế Các-bon (World Bank 2014):

- ETS (Hệ thống giới hạn và thương mại) - giới hạn tổng mức phát thải khí nhà kính và cho phép những ngành có lượng phát thải thấp bán phụ cấp của họ cho các nhà phát thải lớn hơn. Bằng cách tạo ra cung và cầu cho phép phát thải, ETS thiết lập giá thị trường cho phát thải khí nhà kính.

- Thuế Các-bon trực tiếp định giá Các-bon bằng cách xác định thuế suất đối với lượng khí thải gây hiệu ứng nhà kính hoặc đối với hàm lượng Các-bon của nhiên liệu hóa thạch. Không giống như hệ thống thương mại hạn mức phát thải, thuế Các-bon không đảm bảo mức giảm phát thải tối đa. Thay vào đó, cơ chế này cung cấp sự chắc chắn về chi phí biên của việc thải $\mathrm{CO}_{2}$. Vì thuế Các-bon định giá trên mỗi tấn khí nhà kính thải ra, công cụ này sẽ khuyến khích các doanh nghiệp giảm phát thải để hạn chế mức thuế phải nộp.

Việc lựa chọn giải pháp nào sẽ phụ thuộc vào bối cảnh kinh tế của từng quốc gia. Ngoài ra còn có nhiều cách gián tiếp để định giá Các-bon chính xác hơn, chẳng hạn như thông qua thuế nhiên liệu, loại bỏ trợ cấp nhiên liệu hóa thạch và các quy định có thể đưa vào "chi phí xã hội của Các-bon" (World Bank 2014). Phát thải khí nhà kính cũng có thể được định giá thông qua các khoản thanh toán cho việc giảm phát thải. Các tổ chức tư nhân có thể mua các khoản giảm phát thải để bù đắp cho lượng phát thải của chính họ (được gọi là tín chỉ bôii hoàn) hoặc hỗ trợ các hoạt động giảm thiểu thông qua chi trả dựa trên kết quả (World Bank 2014). Khoảng 40 quốc gia và hơn 20 thành phố, tiểu bang và tỉnh đã sử dụng cơ chế định giá Các-bon, từ đó giảm được khoảng 13\% lượng phát thải khí nhà kính toàn câu hàng năm (World Bank 2014).

Tính tới năm 2015, có 15 quốc gia và chính quyền tỉnh đang thực hiện thuế Các-bon nội địa (The PMR 2015).

Ngoài các quốc gia trong Bảng 7, Trung Quốc cũng đang xem xét áp dụng thuế Các-bon. Tại Australia, định giá Các-bon bao gồm giá Cácbon cố định (thuế Các-bon) trong giai đoạn đầu, sau đó sẽ được chuyển đổi sang chế độ thương mại giảm phát thải.

Reinaud và Philibert (2007) đã nhấn mạnh các bài học kinh nghiệm khi xây dựng thuế Cácbon như sau:

- thuế Các-bon nên áp dụng tăng dần bằng cách tăng mức thuế suất theo thời gian hoặc dần dần mở rộng phạm vi áp dụng thuế và loại bỏ các khoản miễn trừ và hoàn thuế cho các ngành công nghiệp nhạy cảm

- thuế Các-bon nên thông qua việc giảm các loại thuế không phù hợp, hỗ trợ trực tiếp các mục tiêu hộ gia đình, khuyến khích nghiên cứu và phát triển, tiết kiệm hiệu quả năng lượng và năng lượng tái tạo

Ngoài ra, có 3 phương án thiết kết thuế Cácbon (Reinaud và Philibert 2007):

1. Thuế áp dụng trực tiếp đối với lượng phát thải KNK đo được

2. Thuế đầu vào nhiên liệu hóa thạch đối với than, dầu thô và khí tự nhiên, dựa trên hàm lượng Các-bon của chúng

3. Thuế đánh vào đâu ra năng lượng (điện và nhiên liệu vận tải). 
Bảng 7. Các quốc gia áp dụng thuế Các-bon

\begin{tabular}{|c|c|c|c|c|c|}
\hline \multicolumn{2}{|c|}{ Quốc gia } & \multirow{2}{*}{$\begin{array}{l}\text { Cấp độ } \\
\text { Địa } \\
\text { phương }\end{array}$} & \multirow{2}{*}{$\begin{array}{l}\text { Năm thực } \\
\text { hiện } \\
2008\end{array}$} & \multirow{2}{*}{$\begin{array}{l}\text { Tổng quan/Phạm vi } \\
\text { Áp dụng với việc mua và sử dụng nguyên liệu ở } \\
\text { trong tỉnh. Thuế các-bon có doanh thu trung lập, tất } \\
\text { cả thuế thu được sẽ quay trở về với người dân thông } \\
\text { qua việc giảm các loại thuế khác }\end{array}$} & \multirow{2}{*}{$\begin{array}{l}\text { Mức thuế carbon } \\
\text { CAD 30/tCO } \mathrm{e} \\
(2012)\end{array}$} \\
\hline 1 & $\begin{array}{l}\text { British } \\
\text { Columbia/ } \\
\text { Canada }\end{array}$ & & & & \\
\hline 2 & Chile & Quốc gia & 2014 & $\begin{array}{l}\text { Một loại thuế đánh vào khí thải từ nồi hơi và tuabin } \\
\text { có đầu vào nhiệt bằng hoặc lớn hơn } 50 \text { megawatt } \\
\text { (MWt) }\end{array}$ & $\begin{array}{l}\text { USD } 5 / \mathrm{tCO}_{2} \mathrm{e} \\
(2018)\end{array}$ \\
\hline 3 & Costa Rica & Quốc gia & 1997 & $\begin{array}{l}\text { Doanh thu do thuế tạo ra được chuyển cho chương } \\
\text { trình Chi trả Dịch vụ Môi trường (PSA), chương trình } \\
\text { khuyến khích các bên có liên quan thực hiện phát } \\
\text { triển bền vững và bảo tồn rừng }\end{array}$ & $\begin{array}{l}\text { Thuế 3,5\% } \\
\text { đối với nhiên } \\
\text { liệu hóa thạch } \\
\text { hydrocacbon }\end{array}$ \\
\hline 4 & Đan mạch & Quốc gia & 1992 & $\begin{array}{l}\text { Thuế Các-bon của Đan Mạch bao gồm tất cả việc } \\
\text { tiêu thụ nhiên liệu hóa thạch (khí đốt tự nhiên, dầu } \\
\text { mỏ và than đá), với các điều khoản miễn và hoàn } \\
\text { trả một phần cho các lĩnh vực thuộc phạm vi điêuu } \\
\text { chỉnh của EU ETS, các quy trình sử dụng nhiều năng } \\
\text { lượng, hàng hóa xuất khẩu, nhiên liệu trong các nhà } \\
\text { máy lọc dâuu và nhiểu lĩnh vực liên quan đến các } \\
\text { hoạt động vận tải. Nhiên liệu được sử dụng để sản } \\
\text { xuất điện không bị đánh thuế Các-bon mà thay vào } \\
\text { đó là thuế sản xuất điện được áp dụng }\end{array}$ & $\begin{array}{l}\text { USD } 31 / \mathrm{tCO}_{2} \mathrm{e} \\
(2014)\end{array}$ \\
\hline 5 & Phần Lan & Quốc gia & 1990 & $\begin{array}{l}\text { Mặc dù ban đầu chỉ dựa trên hàm lượng Các-bon, } \\
\text { thuế Các-bon của Phần Lan sau đó đã được thay } \\
\text { đổi thành thuế Các-bon cho các loại năng lượng } \\
\text { kết hợp. Ban đâu chỉ bao gồm sản xuất nhiệt điện } \\
\text { nhưng sau đó đã được mở rộng cho cả lĩnh vực vận } \\
\text { chuyển và nhiên liệu sưởi ấm }\end{array}$ & $\begin{array}{l}\text { EUR 35/tCO }{ }_{2} \mathrm{e} \\
(2013)\end{array}$ \\
\hline 6 & Pháp & Quốc gia & 2014 & $\begin{array}{l}\text { Thuế tiêu thụ nội địa đối với các sản phẩm năng } \\
\text { lượng dựa trên hàm lượng } \mathrm{CO}_{2} \text { trong tiêu thụ nhiên } \\
\text { liệu hóa thạch không thuộc phạm vi điểu chỉnh của } \\
\text { EU ETS. Thuế Các-bon đã được áp dụng từ ngày } 1 \\
\text { tháng } 4 \text { năm } 2014 \text { đối với việc sử dụng khí đốt, dầu } \\
\text { nhiên liệu nặng và than đá, tăng lên } € 14,5 \text { / tCO } \\
\text { vào năm } 2015 \text { và } € 22 / \text { tCO vào năm } 2016 \text {. Từ năm } \\
2015 \text { trở đi, thuế Các-bon sẽ được mở rộng đối với } \\
\text { vận tải, nhiên liệu và dấu đốt }\end{array}$ & $\begin{array}{l}\text { EUR 7/tCO } \mathrm{e} \\
(2014)\end{array}$ \\
\hline 7 & Iceland & Quốc gia & 2010 & $\begin{array}{l}\text { Tất cả các nhà nhập khẩu và xuất khẩu nhiên liệu } \\
\text { hóa thạch lỏng (dầu khí và dầu diesel, xăng, máy bay } \\
\text { và nhiên liệu máy bay và dầu nhiên liệu) đều phải } \\
\text { chịu thuế Các-bon bất kể đó là để bán lẻ hay sử dụng } \\
\text { cho mục đích cá nhân. Thuế Các-bon đối với nhiên } \\
\text { liệu hóa thạch lỏng được nộp cho kho bạc, với mức } \\
\text { thuế phản ánh giá Các-bon tương đương 75\% giá } \\
\text { hiện tại trong chương trình ETS của EU }\end{array}$ & $\begin{array}{l}\text { USD } 10 / \mathrm{tCO}_{2} \mathrm{e} \\
(2014)\end{array}$ \\
\hline 8 & Ireland & Quốc gia & 2010 & $\begin{array}{l}\text { Thuế Các-bon được giới hạn đối với những lĩnh } \\
\text { vực bên ngoài EU ETS, cũng như các chương trình } \\
\text { loại trừ hầu hết khí thải từ hoạt động nông nghiệp. } \\
\text { Thay vào đó, thuế áp dụng cho xăng, dầu nặng, dầu } \\
\text { diesel tự động, dầu hỏa, khí dầu mỏ lỏng, dầu nhiên } \\
\text { liệu, khí đốt tự nhiên, than đá và than bùn, cũng như } \\
\text { xăng hàng không }\end{array}$ & $\begin{array}{l}\text { EUR 20/tCO } \mathrm{e} \\
(2013)\end{array}$ \\
\hline
\end{tabular}


Bảng 7. Tiếp trang trước

\begin{tabular}{|c|c|c|c|c|c|}
\hline \multicolumn{2}{|c|}{ Quốc gia } & \multirow{2}{*}{$\begin{array}{l}\text { Cấp độ } \\
\text { Quốc Gia }\end{array}$} & \multirow{2}{*}{$\begin{array}{l}\text { Năm thực } \\
\text { hiện } \\
2012\end{array}$} & \multirow{2}{*}{$\begin{array}{l}\text { Tổng quan/Phạm vi } \\
\text { Thuế giảm thiểu biến đổi khí hậu của Nhật Bản bao gồm } \\
\text { việc sứ dụng tất cả các nhiên liệu hóa thạch như dầu, } \\
\text { khí đốt tự nhiên và than, tùy thuộc vào lượng khí thải } \\
\mathrm{CO}_{2} \text { của chúng. Cụ thể, bằng cách sử dụng hệ số phát } \\
\text { thải } \mathrm{CO}_{2} \text { cho từng lĩnh vực, thuế suất trên một đơn vị số } \\
\text { lượng được quy định sao cho mỗi gánh nặng thuế tương } \\
\text { đương } 2 \text { đô la Mỹ / tCO (tính đến tháng } 4 \text { năm 2014) }\end{array}$} & \multirow{2}{*}{$\begin{array}{l}\text { Mức thuế carbon } \\
\text { USD2/tCO } \mathrm{e} \\
(2014)\end{array}$} \\
\hline 9 & Nhật Bản & & & & \\
\hline 10 & Mexico & Quốc gia & 2010 & $\begin{array}{l}\text { Thuế Các-bon của Mexico bao gồm việc bán và nhập } \\
\text { khẩu nhiên liệu hóa thạch của các nhà sản xuất, nhà } \\
\text { xử lý và nhà nhập khẩu. Đây không phải là thuế đánh } \\
\text { vào hàm lượng Các-bon đầy đủ của nhiên liệu, mà } \\
\text { là đánh vào lượng khí thải bổ sung sẽ được tạo ra } \\
\text { nếu nhiên liệu hóa thạch được sử dụng thay vì khí tự } \\
\text { nhiên. Do đó, khí tự nhiên không phải chịu thuế Các- } \\
\text { bon, mặc dù nó có thể là trong tương lai. Thuế suất } \\
\text { được giới hạn ở mức 3\% giá bán nhiên liệu. Các công } \\
\text { ty chịu trách nhiệm nộp thuế có thể chọn nộp thuế } \\
\text { Các-bon bằng các khoản tín dụng từ các dự án CDM } \\
\text { được phát triển ở Mexico, tương đương với giá trị của } \\
\text { khoản tín dụng tại thời điểm nộp thuế }\end{array}$ & $\begin{array}{l}\text { Mex } \$ 10-50 / \\
\mathrm{tCO}_{2} \mathrm{e}(2014) \text { (tuỳ } \\
\text { thuộc vào loại } \\
\text { nhiên liệu) }\end{array}$ \\
\hline 11 & Na Uy & Quốc gia & 1991 & $\begin{array}{l}\text { Khoảng } 55 \% \text { lượng khí thải } \mathrm{CO}_{2} \text { ở } \mathrm{Na} \text { Uy được đánh } \\
\text { thuế trên thực tế. Khí thải không bị đánh thuế nằm } \\
\text { trong ETS của quốc gia, được liên kết với ETS của EU } \\
\text { năm } 2008\end{array}$ & $\begin{array}{l}\text { USD 4-69/tCO } \\
(2014)^{*} \\
\text { *Tùy thuộc vào } \\
\text { nguyên liệu và } \\
\text { cách sử dụng }\end{array}$ \\
\hline 12 & Nam Phi & Quốc gia & 2006 & $\begin{array}{l}\text { Nam Phi có kế hoạch đưa ra mức thuế Các-bon ở mức } \\
\text { R120 cho mối tấn } \mathrm{CO}_{2} \mathrm{e} \text {, với mức tăng hàng năm bắt đầu } \\
\text { từ tháng } 1 \text { năm } 2016 \text {. Mức thuế này được hình dung là } \\
\text { thuế đầu vào nhiên liệu dựa trên hàm lượng Các-bon } \\
\text { của nhiên liệu và bao gồm tất cả lượng phát thải khí nhà } \\
\text { kính trực tiếp cố định từ cả hai đốt cháy nhiên liệu và } \\
\text { phát thải quá trình công nghiệp phi năng lượng, chiếm } \\
\text { khoảng } 80 \% \text { tổng lượng phát thải KNK }\end{array}$ & $\begin{array}{l}\mathrm{R} 120 / \mathrm{tCO}_{2} \text { (Thuế } \\
\text { được đề xuất cho } \\
\text { năm 2016)* } \\
\text { *Tùy thuộc vào } \\
\text { nguyên liệu và } \\
\text { cách sử dung }\end{array}$ \\
\hline 13 & Thụy Điển & Quốc Gia & 1991 & $\begin{array}{l}\text { Thuế Các-bon của Thụy Điển chủ yếu được áp dụng } \\
\text { như một phần của cải cách ngành năng lượng, với } \\
\text { các lĩnh vực bị đánh thuế chính bao gồm khí đốt tự } \\
\text { nhiên, xăng, than đá, dầu nhiên liệu nhẹ và nặng, } \\
\text { khí hóa lỏng và dầu sưởi ấm. Trong những năm qua, } \\
\text { việc miễn thuế Các-bon đã tăng lên đối với các thiết } \\
\text { bị lắp đặt theo EU ETS, với sự gia tăng mức miễn gần } \\
\text { đây nhất bắt đầu từ năm } 2014 \text { đối với các nhà máy } \\
\text { sưởi cấp huyện tham gia EU ETS }\end{array}$ & $\begin{array}{l}\text { USD 168/ } \mathrm{tCO}_{2} \mathrm{e} \\
(2014)\end{array}$ \\
\hline 14 & Thụy Sĩ & Quốc gia & 2008 & $\begin{array}{l}\text { Thuế Các-bon của Thụy Sĩ bao gồm tất cả các nhiên } \\
\text { liệu hóa thạch, trừ khi chúng được sử dụng cho phát } \\
\text { triển năng lượng. Các công ty Thụy Sĩ có thể được } \\
\text { miễn thuế nếu họ tham gia vào ETS quốc gia }\end{array}$ & $\begin{array}{l}\text { USD 68/ USD 68/ } \\
\mathrm{tCO}_{2} \mathrm{e}(2014)\end{array}$ \\
\hline 15 & UK & Quốc gia & 2013 & $\begin{array}{l}\text { Giá sàn Các-bon của Vương quốc Anh là thuế đánh vào } \\
\text { nhiên liệu hóa thạch được sử dụng để tạo ra điện. Nó có } \\
\text { hiệu lực vào tháng } 4 \text { năm } 2013 \text { và thay đổi chế độThuế } \\
\text { Biến đổi Khí hậu hiện có trước đây, bằng cách áp dụng } \\
\text { mức hỗ trợ giá Các-bon đối với khí đốt, nhiên liệu rắn và } \\
\text { khí hóa lỏng được sử dụng trong sản xuất điện }\end{array}$ & $\begin{array}{l}\text { USD 15.75/ } \mathrm{tCO}_{2} \mathrm{e} \\
(2014)\end{array}$ \\
\hline
\end{tabular}




\section{Quy định và khung pháp lí quốc tế liên quan đến quyền Các-bon, quyền phát thải và chia sẻ lợi ích}

Do Các-bon rừng và giảm phát thải từ phá rừng và suy thoái rừng trở thành hàng hóa quan trọng trên thị trường giao dịch giảm phát thải trên toàn cầu, chính sách và cơ chế vận hành lưu thông hàng hóa này cũng như quyền Các-bon, chứng nhận quyền phát thải ngoài việc phải đảm bảo hài hóa với các chính sách hiện hành của mỗi quốc gia còn phải tuân thủ chặt chẽ các quy định và luật chơi quốc tế. Việc chuyển giao quyền Các-bon nội địa cũng sẽ có cách vận hành rất khác so với chuyển quyền Các-bon quốc tế.

\subsection{Chuyển quyền Các-bon nội địa}

Cho tới nay chưa có một định nghĩa thống nhất cũng như quy định quốc tế hướng dẫn việc định nghĩa quyền Các-bon. Tuy nhiên, Bảng 8 cho một khung phương pháp và cách tiếp cận, cũng như các câu hỏi cân phải được trả lời để xây dựng chính sách về quyền và chuyển quyền Các-bon.

Bảng 9 trình bày một số ví dụ các nước đã áp dụng phương pháp tiếp cận trên để xây dựng chính sách liên quan đến quyền Các-bon của mình.

Bảng 8. Các vấn đề cần xem xét khi xây dựng chính sách về quyền Các-bon.

\begin{tabular}{|c|c|}
\hline Các bước đánh giá & Các giải pháp lựa chọn để quốc gia xem xét \\
\hline $\begin{array}{l}\text { 1. Xác định phương án xây dựng chính sách } \\
\text { về quyền Các-bon }\end{array}$ & $\begin{array}{l}\text { - Phương án 1. Tạo ra một chính sách/hướng dẫn/nghị định mớ } \\
\text { cụ thể hóa về quyền Các-bon } \\
\text { - Phương án } 2 \text {. Sửa đổi và sử dụng các chính sách hiện hành }\end{array}$ \\
\hline $\begin{array}{l}\text { 2. Các khía cạnh cần xem xét trong quy định } \\
\text { về quyền Các-bon. Quyền Các-bon bao } \\
\text { gồm } 3 \text { khía canh: } \\
\text { - Quyền đối với Các-bon chứa trong sinh } \\
\text { khối của cây và rừng } \\
\text { - Quyền được hưởng lợi ích từ việc cung } \\
\text { cấp dịch vụ hấp thụ và tránh mất Các- } \\
\text { bon } \\
\text { - Quyền đối với các chứng nhận giảm } \\
\text { phát thải và tín chỉ Các-bon thường } \\
\text { được hiểu là quyền để tiến hành giao } \\
\text { dịch thương mại như một mặt hàng } \\
\text { như được định nghĩa bởi các quy định } \\
\text { pháp lí trong nước và ngoài nước (thị } \\
\text { trường bắt buộc) và các tiêu chuẩn hợp } \\
\text { đồng (thị trường Các-bon tự nguyện) }\end{array}$ & 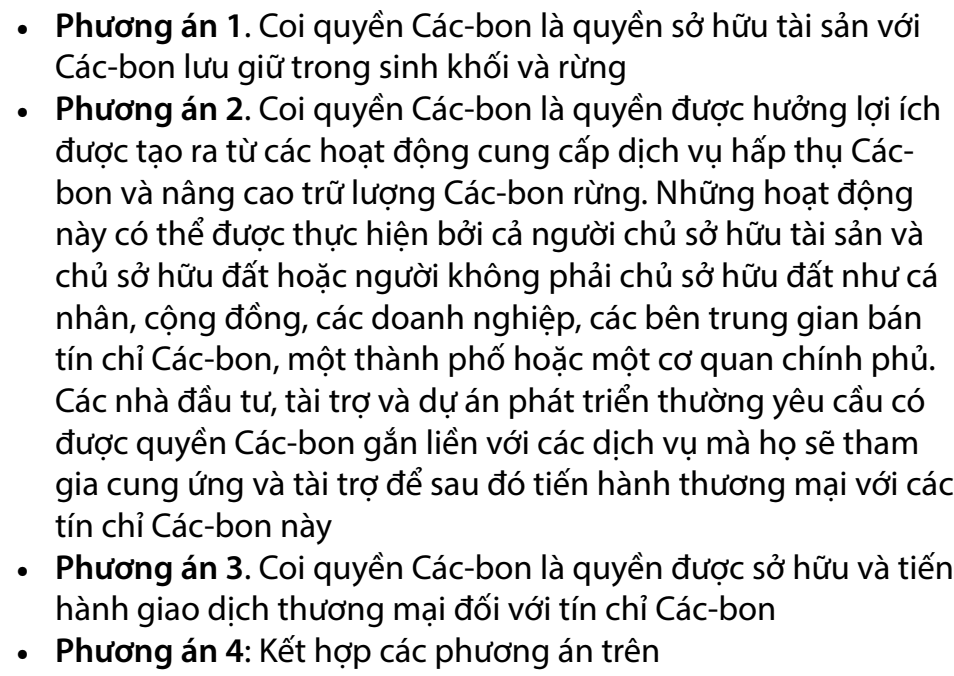 \\
\hline
\end{tabular}

3. Cơ chế chia sẻ lợi ích liên quan đến Cácbon và giảm phát thải mà quốc gia lựa chọn, từ đó xây dựng quyền Các-bon phù hợp với cơ chế này

Quyết định UNFCCC 9-15/CP. 19; 1/CP. 17 quy định rằng cơ chế thị trường và cơ chế phi thị trường đều phải thực hiện chia sẻ lợi ích từ các hoạt động về REDD+. Cho tới nay, có 3 cơ chế chia sẻ lợi ích hiện đang được các quốc gia xem xét và thảo luận và sẽ có ảnh hưởng then chốt tới chính sách liên quan đến quyền Các-bon 
Bảng 8. Tiếp trang trước

\begin{tabular}{ll}
\hline Các bước đánh giá & Các giải pháp lựa chọn để quốc gia xem xét \\
\hline Phương án 1. Hệ thống kế toán quốc gia: \\
- Chính quyê̂n trung ương đại diên cho quốc gia cam kết giảm phát \\
thải được thẩm định. Để có thể giảm phát thải, chính phủ thực \\
hiện các chính sách và biện pháp (PAM) để thay đổi hành vi và \\
tạo ra kết quả giảm phát thải tữ đó nhận được chi trả theo cơ chế \\
quốc tế cho những chính sách mà họ đã thực hiện
\end{tabular}

\section{Phương án 2. Hệ thống kế toán quốc gia với sự thực hiện của} cấp tỉnh cùng kết hợp/hoặc theo dự án

\section{Phương án 3: Thực hiện theo chương trình và dự án. \\ Đối với cả phương án 2 và phương án 3 :}

- Cho phép sự tham gia trực tiếp của các tổ chức tư nhân tại cấp tỉnh thông qua cơ chế thị trường như cơ chế thị trường thương mại phát thải của California (USA) và Acre (Brazil), và các sáng kiến khác khi người mua giảm phát thải có thể trực tiếp làm việc với chủ rừng thông qua thị trường Các-bon tự nguyện. Trong trường hợp này, bên thực hiện dự án cần làm rõ ai là người sở hữu và quản lí rừng. Những người chịu trách nhiệm cho các hoạt động phát thải cần được đảm bảo quyền lâu dài và đảo bảo họ có thể được thưởng khi thực hiện thành công giảm phát thải hoặc chịu trách nhiệm khi không thực hiện đúng như hợp đồng và cam kết. Để các chủ rừng đòi quyền hưởng lợi từ chi trả dựa vào kết quả dựa theo cơ chế thị trường, họ cần chứng minh họ có quyền sở hữu với Các-bon lưu giữ trong rừng hoặc quyền hưởng lợi từ việc thực hiện các hoạt động dẫn tới hấp thụ Cácbon rừng và giảm phá rừng suy thoái rừng

- Đã vận hành và bán tín chỉ Các-bon trong thị trường Các-bon tự nguyện nhưng chưa có quy định quốc tế nào về chuyển quyền Các-bon

- Luật pháp quốc gia phải quy định rõ ai sở hữu bể chứa Các-bon và việc sở hữu này có bao gồm cả quyền được hưởng lợi

- Nếu tín chỉ giảm phát thải được vận hành, các hoạt động có khả năng được chứng nhận và các tiêu chuẩn môi trường, xã hội đi kèm sẽ phải được xác định cụ thể trong luật pháp quốc gia và phải khác với cơ chế $C D M$ hoặc cơ chế thị trường tự nguyện

4. Chuyển quyền Các-bon

- Phương án 1. Tách biệt độc lập như một quyền mới trong hệ thống pháp lý mới được xây dựng

- Phương án 2. Quá trình chuyển quyền Các-bon gắn liền với các quyền quản lý và chuyển giao tài nguyên thiên nhiên. Khi một bên sở hữu hoặc được cấp quyền quản lý tài nguyên thiên nhiên, bên này sẽ có quyền hưởng lợi từ tài nguyên này (trong đó có Các-bon)

- Phương án 3. Quá trình chuyển quyền Các-bon gắn liền với các quyền sở hữu đất đai. Bởi quyền Các-bon gắn liền với quyền sở hữu đất đai, chủ sở hữu đất có toàn quyền sở hữu, quyền sử dụng hoặc quyền quản lý, theo các hệ thống pháp luật theo quy định và theo thông lệ truyền thống. Người chủ đất cũng có quyền quản lý và quyền thiết lập các quy tắc và chế tài mà theo đó rừng có thể được quản lý (ví dụ: nhượng quyền quản lý thương mại hoặc cộng đồng). Các quyền này có thể được có thể chuyển nhượng hoặc không thể chuyển nhượng được tùy theo luật pháp quốc gia. Các chủ rừng cũng có thể tiến hành liên kết với một cá nhân hoặc tổ chức cụ thể. 
Bảng 8. Tiếp trang trước

\begin{tabular}{|c|c|}
\hline Các bước đánh giá & Các giải pháp lựa chọn để quốc gia xem xét \\
\hline 5. Quyền đối với tài sản & $\begin{array}{l}\text { - Phương án 1. Toàn quyền sở hữu. Một bên có quyền đối với tài } \\
\text { sản, họ có toàn quyền quyết định đối với tài sản đó không ? } \\
\text { - Phương án 2. Có phân quyền sử dụng. Một bên có quyền đối } \\
\text { với tài sản, nhưng chỉ được có quyền với một số hoạt động cụ } \\
\text { thể, còn một số quyển quyết định đến các hoạt động khác phải } \\
\text { được quy định hoặc phân bổ bởi một bên khác }\end{array}$ \\
\hline 6. Người nắm giữ quyền Các-bon & $\begin{array}{l}\text { - Phương án 1. Nhà nước và coi đó tài sản công } \\
\text { - Phương án 2. Tài sản tư của cộng đồng } \\
\text { - Phương án 3. Tài sản cá nhân }\end{array}$ \\
\hline $\begin{array}{l}\text { 7. Chịu trách nhiệm hoặc bị phạt nếu không } \\
\text { thực hiện đúng nghĩa vụ }\end{array}$ & $\begin{array}{l}\text { - Phương án 1. Đi kèm với người giữ quyền Các-bon } \\
\text { - Phương án 2. Được xác định bởi luật cụ thể } \\
\text { - Phương án 3. Xác định bởi luật chơi thị trường và hợp đồng } \\
\text { kinh tế }\end{array}$ \\
\hline
\end{tabular}

Nguồn: Nhóm tác giả tổng hợp và phân tích, Loft và cộng sự (2015); Streck (2020)

Bảng 9. Ví dụ về chính sách liên quan quyền Các-bon ở Brazil và Peru

\section{Chính sách liên quan đến quyền Các-bon}

Brazil - Chiến lược REDD+ quốc gia chỉ rõ phương thức tính toán quốc gia về cắt giảm phát thải và chia sẻ lợi ích với các bang. Các bên có liên quan tại địa phương sẽ nhận và chia sẻ lợi ích dựa trên đóng góp vào việc phát thải từ phá rừng

- Các bang sẽ tiến hành chia sẻ lợi ích sử dụng các tiêu chí riêng của mình nhưng phải tuân theo hướng dẫn chung của Cơ quan điều phối REDD+

- Hiện nay cơ chế chia sẻ lợi ích ở cấp Bang nổi bật nhất là qua quỹ Amazon- một cơ chế chi trả dựa vào kết quả được tạo ra vào năm 2008. Quỹ Amazon có nhiệm vụ tìm kiếm tài trợ không hoàn lại cho những nỗ lực tránh và giảm thiểu phá rừng và suy thoái rừng, quản lí rừng bền vững tại khu vực Amazon Biome. Gây quỹ Amazon gắn liền với điều kiện sẽ giảm tî lệ phá rừng hàng năm tại Brazil. Không rõ Quỹ sẽ giám sát việc đóng góp của Quỹ với việc giảm phát thải thế nào.

- Kết quả giảm phát thải sẽ được các nước phát triển ( $\mathrm{Na} U y$, Đức) chi trả và các nhà tài trợ sẽ nhận một giấy chứng nhận có giá trị danh nghĩa, không thể chuyển nhượng và không tạo ra các quyền Các-bon dưới bất kỳ hình thức nào

- Ngoài Quỹ Amazon, các bang còn đề xuất một cơ chế PES quốc gia để phân bổ lợi ích từ chi trả cho giảm phát thải

- Hiện nay các bang đều không có chính sách cụ thể về quyền Các-bon, nhưng theo Hiến Pháp và Luật Dân sự thì quyền Các-bon có thể gắn liền với quyền sở hữu tài nguyên và tài sản

- Đối với diện tích do tư nhân quản lí, Chiến lược REDD+ quy định khối tư nhân sẽ được hỗ trợ bởi các cơ chế tài chính tích cực (trợ cấp môi trường, $\mathrm{PES}$, cải cách thuế) để cam kết giảm phá rừng và tạo ra quyền có thể chuyển nhượng được. Quyền này bao gồm quyền sở hữu tài sản rừng sẽ được phân bổ, chuyển nhượng dựa trên hạn mức được quy định bởi chính quyền bang về sử dụng tài nguyên thiên nhiên như Luật lâm nghiệp. Nói một cách khác, dù chính quyền bang không có quy định về quyền Các-bon, quyền Các-bon sẽ đi theo các quy định về quyền sở hữu tài nguyên và cung cấp dịch vụ giảm phát thải

- Đối với diện tích rừng do nhà nước quản lí. Luật quản lí rừng nhà nước cùng nhiều quy định khác cấm việc thương mại hóa các hoạt động và lợi ích Các-bon, trừ các hoạt động tái sinh rừng. Các quy định này cũng ghi rõ chỉ có nhà nước mới có toàn quyền quyết định với các diện tích rừng cho thuê hoặc chuyển nhượng và do vậy là bên duy nhất sở hữu quyền Các-bon cho diện tích rừng nhà nước quản lí

- Trường hợp ngoại lệ đối với diện tích do người dân tộc thiểu số quản lí. Mặc dù diện tích đất của người dân tộc thiểu số nằm ở diện tích đất do Chính quyền bang quản lí, theo hiến pháp, người dân tộc thiểu số có toàn quyền quyết định các lợi ích tạo ra từ diện tích mà họ quản lí, bao gồm cả quyền Các-bon. 
Bảng 9. Tiếp trang trước

\section{Chính sách liên quan đến quyền Các-bon}

- Tại các khu vực khu bảo tồn: quyền Các-bon được tạm thời trao cho Quỹ bền vững Amazonas (FAS)một quỹ đang chịu trách nhiệm điều hành và quản lí chương trình Chi trả dịch vụ môi trường Bolsa Floresta Program, chương trình PES của bang. FAS cần phải tuân thủ các quy định về quản lí tài chính trong việc thương thảo các thỏa thuận liên quan đến giảm phát thải. FAS đã có những thảo luận về thỏa thuận giảm phát thải đối với khối tư nhân trên thị trường Các-bon tự nguyện. Những người cung cấp dịch vụ môi trường rừng trong hợp đồng có quyền được hưởng lợi từ nguồn thu này nhưng phải chứng minh được rằng họ có sở pháp lí về đất đai và dịch vụ mà họ cung cấp

- Gần đây chính quyền Liên bang Amazon đề xuất cơ chế phân bổ tín chỉ và quyền giảm phát thải - gọi là đơn vị REDD+ (U-REDD+). Theo cơ chế này, việc phân bổ sẽ được thực hiện cho cả các cơ quan nhà nước và các đối tượng khác (ví dụ: cộng đồng dân cư, người dân tộc thiểu số) U-REDD+ sẽ được chia cho chính quyền liên bang khoảng $20 \%$ và cho từng bang riêng lẻ là $80 \%$. Họ đề xuất U-REDD+ nên được phân bổ dựa trên sự đóng góp của mỗi bang đối với việc giảm nạn phá rừng và bảo tồn và nâng cao lượng Các-bon được lưu trữ trong khu vực có rừng của bang.

- Chưa rõ việc chuyển giao quyền Các-bon giữa chính quyền liên bang và từng bang sẽ được tiến hành như thế nào.

Peru Chọn phương án chia sẻ lợi ích lồng ghép với hệ thống tài chính quốc gia kết hợp với việc thực hiện tại cấp tỉnh hoặc dự án nhằm gắn sáng kiến chi trả dựa vào kết quả của thị trường Các-bon quốc tế. Chính quyền bang sẽ là người được hưởng lợi cũng như phải chịu trách nhiệm trong việc cung cấp và đảm bảo Các-bon trong diện tích đất mà họ quản lí

- Lợi ích tiền tệ sẽ được chảy từ chính quyền trung ương xuống chính quyền bang dựa vào đóng góp của mỗi bang trong việc giảm phát rừng và suy thoái rừng cũng như bảo tồn bể chứa Các-bon quốc gia.

- Chính quyền khu vực bang sẽ phân bổ lợi ích tới các bên tại cấp tỉnh bao gồm cộng đồng dân tộc thiểu sổ, bên tư nhân, bên thuê dịch vụ môi trường rừng cũng như các cơ quan nhà nước đang quản lí vườn quốc gia, khu bảo tồn và các diện tích rừng chưa được phân loại

- Một phần tiền chuyển về từ trung ương cũng sẽ được sử dụng để trang trải các hoạt động quản lí cho chính quyền địa phương và vùng

- Tuy nhiên, nếu là cơ chế lồng ghép, thì các dự án cấp địa phương sẽ bán tín chỉ Các-bon trên thị trường tự nguyện như thế nào ? Peru có dự định vẫn cho phép các dự án tiếp tục bán tín chỉ Các-bon cho thị trường tự nguyện dù quốc gia đang hướng tới thị trường trong nước và quốc tế bắt buộc. Chưa rõ việc vận hành ở cấp quốc gia nhưng chính quyền bang lại thực hiện các dự án với thẩm định độc lập sẽ được hài hòa hóa thế nào.

- Một số chính sách hiện hành của Peru cũng có những ảnh hưởng nhất định tới việc xây dựng chính sách quyền Các-bon tại nước này. Cụ thể hơn:

- Năm 2010, MINAM đã kí thỏa thuận với Chính quyền bang cũng như cộng đồng địa phương để bảo tồn 54 triệu hecta rừng và đã chi trả cho hơn 2325 hộ gia đình cũng như chính quyền địa phương để họ cung cấp dịch vụ bảo tồn rừng.

- Một Chỉ thị được đệ trình vào 2013 bởi Cơ quan quản lí Khu bảo Tồn (SERNANP) thuộc MINAM đề xuất SERNANP là chủ sở hữu của Các-bon và tất cả các quyền hưởng lợi từ rừng (sỡ hữu và bán tín chỉ Cácbon), và từ diện tích đất trong khu bảo tồn và vùng đệm. Điều này có nghĩa là các dự án thực hiện trong phạm vi khu bảo tồn có mong muốn nhận được chứng chỉ giảm phát thải, dù là theo cơ chế chứng chỉ và tiêu chuẩn nào đi nữa, cũng sẽ phải kí thỏa thuận với SERNANP về việc lợi ích sẽ được phân chia như thế nào. SERNANP có toàn quyền quyết định cho chuyển quyền Các-bon và chứng chỉ phát thải cho bên thứ 3 bao gồm các dự án REDD+. Lợi ích có được từ việc bán tín chỉ Các-bon sẽ được chuyển vào một tài khoản ngân hàng được tạo ra cho dự án và quản lí bởi chính quyền trung ương. Tiền lăi từ tài khoản này sẽ được chuyển về một quỹ đặc biệt để hỗ trợ quản lí khu bảo tồn và vùng đệm. Mặc dù SERNANP là chủ sở hữu của quyền Các-bon tạo ra trong khu bảo tồn tự nhiên dưới chỉ thị này, quyền hiện đang được chuyển giao và được giữ bởi bên hành chính thứ 3 (ví dụ NGO) đã kí hợp đồng với SERNANPT để quản lí hoặc đồng quản lí khu bảo tồn và sẽ không được chuyển giao trở lại

- Một vài Luật khác như Hiến pháp quy định tài nguyên thiên nhiên thuộc quyền sở hữu của quốc gia. Chính phủ không có quyền tiến hành thương mại tài nguyên thiên nhiên nhưng có thể cấp quyền và nhượng quyền cho bên thứ 3 . Tuy nhiên sản phẩm và kết quả về quản lí tài nguyên thiên nhiên sẽ thuộc về bên đã được chuyển nhượng quyền (ví dụ: dịch vụ môi trường hấp thụ và lưu trữ Các-bon, làm tăng trữ lượng Các-bon) 
Bảng 9. Tiếp trang trước

\section{Chính sách liên quan đến quyền Các-bon}

- Chính sách Chi trả dịch vụ hệ sinh thái được thông qua năm 2014 cùng với Luật Lâm Nghiệp mới cũng quy định hệ thống pháp lí liên quan đến Các-bon. Trong Luật về PES, dịch vụ hấp thụ Các-bon được coi là một dịch vụ môi trường và người cung cấp dịch vụ Các-bon có thể là cơ quan hành chính công hay tư nhân, người có quyền chính thống và không chính thống. Họ không chỉ bao gồm những người có chứng nhận quyền sở hữu đất mà còn các bên thuê môi trường rừng, bên được chuyển nhượng quyền sử dụng rừng, $\mathrm{NGO}$ có hợp đông hành chính với khu bảo tồn cũng như các đơn vị khác được MINAM thừa nhận. Tuy nhiên, chính sách này lại không làm rõ quyền Các-bon trong các trường hợp tranh chấp và chồng chéo về quyền. Ví dụ, trong trường hợp tranh chấp trong ranh giới khu bảo tồn nhưng lại có diện tích cho thuê để khai thác lâm sản ngoài gỗ.

- Điều đáng nói là Theo chính sách PES thì người hưởng lợi và có quyền với Các-bon nhưng cũng phải tuân thủ nghĩa vụ và trách nhiệm nhất định thì mới có thể có được quyền Các-bon này.

- Tuy nhiên, vì Bộ Nông Nghiệp chịu trách nhiệm quản lí tài nguyên rừng, về mặt pháp lí MINAM cũng có quyền phân bổ quyền Các-bon rừng. Các chủ đất khác cũng có thể được cấp quyền thông qua việc thực hiện các hoạt động quản lí bảo vệ rừng.

Nguồn: Loft và cộng sự (2015)

\subsection{Cơ chế chuyển quyền Các-bon và quyền phát thải quốc tế}

Tín chỉ Các-bon cũng thường được gọi là "chứng chỉ phát thải" vì mỗi đơn vị cho phép được thải ra một tấn Các-bon dioxide $\left(\mathrm{CO}_{2}\right)$ hoặc Các-bon dioxide tương đương $\left(\mathrm{CO}_{2} \mathrm{e}\right)$. Nếu được ban hành bởi một tiêu chuẩn tư nhân, chẳng hạn như Tiêu chuẩn Vàng, thì tín chỉ Các-bon không thể hiện bất kỳ ủy quyền hành chính hay quyền Các-bon nào đi kèm. Nó chỉ là một chứng chỉ riêng có thể giao dịch và độc lập với hoạt động liên quan đến đất đai. Về mặt pháp lý, bồi hoàn Các-bon đòi hỏi sự đảm bảo rằng một hoạt động giảm thiểu đã đáp ứng các tiêu chí xã hội và môi trường nhất định (các biện pháp bảo đảm an toàn và tham vấn). Tín chỉ cácbon được phát hành thể hiện giá trị môi trường hoặc dịch vụ.

Hình 3 cho thấy các cơ chế giao dịch giảm phát thải cùng với cơ chế chuyển quyền Các-bon, chuyển kết quả giảm phát thải tương ứng đang được vận hành trên thế giới.

Bảng 10 cụ thể hóa hơn nội hàm của từng cơ chế và sáng kiến hiện hành trên thế giới và cũng chỉ rõ cùng một sáng kiến nhửng các bên thực hiện có thể đi theo nhiều sự lựa chọn khác nhau (ví dụ Thỏa thuận Paris).
Chi trả dựa vào kết quả đi kèm với điều kiện bắt buộc liên quan đến chuyển quyền giảm phát thải (e.g. FCPF, Điều khoản 6.2 và 6.3 trong thỏa thuận Paris)
Cơ chế giao dịch giảm phát thải

Hình 3. Cơ chế chuyển quyền Các-bon và giấy chứng nhận giảm phát thải

Nguồn: Nhóm tác giả tự tổng hợp (2021)

Chi trả dựa vào kết quả nhưng không yêu cầu chuyển giao quyền giảm phát thải (E.g. Thỏa thuận song phương kí với Na Uy; Điều khoản 6.4 trong Thỏa Thuận Paris, REM)
Tài trợ không hoàn lại với yêu cầu giảm phát thải tương ứng 
Bảng 10. Các cơ chế giao dịch giảm phát thải và quy định liên quan đến chuyển quyền và truy xuất giao dịch giảm phát thải

\begin{tabular}{|c|c|c|}
\hline & Các giao dịch giảm phát thải & Truy xuất giao dịch giảm phát thải \\
\hline Thỏa thuận Paris & $\begin{array}{l}\text { - Điều khoản } 6 \text { của Thỏa Thuận Paris thiết lập } 3 \text { cơ } \\
\text { chế để hỗ trợ các quốc gia đạt được mục tiêu giảm } \\
\text { thiểu của mình: } \\
\text { - Các phương thức hợp tác thông qua sử dụng cơ } \\
\text { chế ITMOs (Điểu 6.2) } \\
\text { - Một cớchế thị trường mới (Điều 6.4) } \\
\text { - Cơ chế phi thị trường (Điều 6.8) } \\
\text { - Điểu khoản 6.2. giới thiệu Chuyển giao kết quả } \\
\text { giảm thiểu biến đổi khí hậu trên toàn câuu (ITMOs) } \\
\text { không quy định chuyển giao giấy chứng nhận } \\
\text { giảm phát thải/quyền Các-bon } \\
\text { - Điê̂u khoản 6.3. quy định ITMOs là tự nguyện hoặc } \\
\text { ủy quyền bởi các quốc gia. } \\
\text { - Chỉ có cơ chế taao ra trong Điều khoản } 6.4 \text {. mới yêu } \\
\text { cầu chuyển giao quyền Các-bon và chứng nhận } \\
\text { giảm phát thải }\end{array}$ & $\begin{array}{l}\text { Điều khoản } 6 \text { nêu rõ các quốc gia } \\
\text { phải áp dụng hệ thống kế toán } \\
\text { và theo dối để đảm bảo không } \\
\text { báo cáo hai lẩn. COP sẽ đưa ra các } \\
\text { hướng dẫn cụ thể vể khung minh } \\
\text { bạch để theo dõi và kiểm tra quá } \\
\text { trình các quốc gia thực hiện các } \\
\text { cam kết NDC của mình (Điều 6.2.) }\end{array}$ \\
\hline Quỹ Các-bon FCPF & $\begin{array}{l}\text { Chi trả cho kết quả. Mua lại giấy chứng nhâan giảm } \\
\text { phát thải. Trong hợp đồng mua bán nêu rố “bất cứ } \\
\text { chuyển giao giảm phát thải nào đêu bao gồm chuyển } \\
\text { giao tất cả các quyê̂n, các chứng nhâan và lợi ích gắn } \\
\text { liền với giảm phát thải đã được chuyển nhượng/ } \\
\text { chuyển giao” }\end{array}$ & $\begin{array}{l}\text { Khung phương pháp yêu cầu các } \\
\text { nước REDD+ có một hệ thống } \\
\text { đăng kí giao dịch ER hoặc sử dụng } \\
\text { một hệ thống được quản lí bởi một } \\
\text { bên thứ 3, và dù trong trường hợp } \\
\text { nào đều cần phải có một hệ thống } \\
\text { kiểm toán độc lập thẩm định hệ } \\
\text { thống đăng kí tín chỉ Các-bon được } \\
\text { công bố rộng rãi cho công chúng }\end{array}$ \\
\hline $\begin{array}{l}\text { Giao dịch song } \\
\text { phương với NICFI }\end{array}$ & $\begin{array}{l}\text { Chi trả dựa vào kết quả, không mua hoặc chuyển } \\
\text { nhượng/chuyển giao giấy chứng nhận }\end{array}$ & $\begin{array}{l}\text { Giảm phát thải được quốc gia báo } \\
\text { cáo và được thẩm định bởi một } \\
\text { bên đồc lập thứ } 3 \text { và cả hai báo cáo } \\
\text { này đều được công bố tới công } \\
\text { chúng một cách rộng rãi }\end{array}$ \\
\hline $\begin{array}{l}\text { Quỹ Khí hậu xanh } \\
\text { (GCF) }\end{array}$ & Chi trả dựa vào kết quả & $\begin{array}{l}\text { Không yêu cầu kí giấy chuyển } \\
\text { nhượng quyển Các-bon nhưng yêu } \\
\text { cầu có hệ thống truy xuất, đăng kí } \\
\text { và giám sát để tránh báo cáo và chi } \\
\text { trả chồng chéo }\end{array}$ \\
\hline Quỹ Amazon & $\begin{array}{l}\text { Chi trả dựa vào kết quả, không mua hoăcc chuyển giao } \\
\text { các giấy chứng nhận. Mỗi giao dịch sẽ thông báo } \\
\text { tổng nguồn tài chính sẽ được đóng góp (như tài trợ) } \\
\text { và lượng giảm phát thải tữ phá rừng và suy thoái rừng } \\
\text { tương ứng cần thiết. Thỏa thuận này không tạo ra } \\
\text { quyền hoặc tín chỉ Các-bon }\end{array}$ & $\begin{array}{l}\text { Viện trợ không hoàn lại nhận từ Na } \\
\text { Uy, Đức, Petrobras, và giấy chứng } \\
\text { nhận về viện trợ này sẽ được ghi } \\
\text { nhận trong hệ thống truy xuất } \\
\text { và được công bố trong báo cáo } \\
\text { hàng năm của quỹ cũng như trên } \\
\text { website }\end{array}$ \\
\hline $\begin{array}{l}\text { REDD+ Early Movers } \\
\text { (REM)/Những người } \\
\text { tiên phong REDD+ }\end{array}$ & $\begin{array}{l}\text { Chi trả cho dịch vụ hệ sinh thái nhưng không yêu cầu } \\
\text { chuyển nhượng hay chuyển giao giấy chứng nhận. Cơ } \\
\text { chế này yêu cầu báo cáo và kiểm toán toàn bộ lượng } \\
\text { giảm phát thải và phát hành trong hệ thống đăng kí }\end{array}$ & $\begin{array}{l}\text { Giảm phát thải phải được ghi nhận } \\
\text { và nằm trong một hệ thống đăng } \\
\text { kí REDD+ quốc gia }\end{array}$ \\
\hline $\begin{array}{l}\text { Thị trường Các-bon } \\
\text { tự nguyện }\end{array}$ & $\begin{array}{l}\text { Tạo ra các tài sản Các-bon có thể thương mại, ví dụ } \\
\text { các dự án VCS đang tạo ra các đơn vị Các-bon được } \\
\text { thẩm định (VCUs) có thể thương mại }\end{array}$ & $\begin{array}{l}\text { Mọi hệ thống đều yêu cầu có một } \\
\text { hệ thống đăng kí, cung cấp số } \\
\text { series và từng VCU có thể truy xuất } \\
\text { online }\end{array}$ \\
\hline
\end{tabular}


Mặc dù có nhiêu sáng kiến và cơ chế, cho tới nay 4 cơ chế và sáng kiến có nhiều ảnh hưởng nhất cũng như có số lượng quốc gia tham gia đông đảo nhất là Thỏa Thuận Paris, Quỹ Các-bon của FCPF, Quỹ GCF và thỏa thuận song phương/đa phương giữa các nhà tài trợ lớn với các nước đang phát triển.

\subsubsection{Thỏa thuân Paris}

Thỏa thuận Paris là thỏa thuận về biến đổi khí hậu và môi trường có ảnh hưởng lớn nhất về quy định thị trường Các-bon cũng như đưa ra các nguyên tắc toàn câu về giao dịch, chuyển nhượng và báo cáo giảm phát thải. Điêu khoản 6 của Thỏa thuận Paris được định hướng là sẽ cung cấp hướng dẫn cụ thể cho các quốc gia và các bên có liên quan trong việc chuyển quyền Các-bon, và tiến hành giao dịch thương mại Các-bon trên toàn cầu. Tuy nhiên, trong 5 năm trở lại đây, chưa có sự thống nhất và cụ thể hóa nào được thông qua tại các cuộc họp COP (Hộp 2). Điêuu này dẫn đến một thực trạng đó là trong thực tế có rất nhiều quốc gia đang phát triển ngân ngại và không muốn chuyển nhượng tín chỉ giảm phát thải bởi bản thân họ phải đảm bảo việc thực hiện cam kết NDC của mình trước tiên. Điều khoản 6 của Thỏa Thuận của Paris sẽ vẫn là trọng tâm thảo luận trong cuộc họp COP vào cuối năm 2021.

\section{Hộp 2. Những điều khoản quan trọng của Thỏa Thuận Paris quyết định cơ chế vận hành của chuyển giao quyền Các-bon và chứng nhận giảm phát thải nhưng chưa được làm rõ}

Điều khoản 6 của Thỏa thuận Paris đóng vai trò quan trọng trong việc các nước sẽ thương mại, chuyển giao chứng nhận giảm phát thải như thế nào. Cụ thể hơn:

- Yêu cầu các quốc gia tham gia hợp tác tự nguyện để đạt được mục tiêu NDC,

- Đề cập tới "chuyển giao kết quả giảm thiểu biến đổi khí hậu trên toàn cầu (ITMOs)

- Cho phép ITMOs có thể tự nguyện hoặc được ủy quyền bởi các quốc gia tham gia

- Đưa ra khuyến khích và cơ chế cho phép khối tư nhân và nhà nước hỗ trợ các dự án giảm thiểu khí hậu từ đó có thể tạo ra các tín chỉ giảm phát thải có thể thương mại và chuyển giao/chuyển nhượng. Các hoạt động giảm thiểu khí hậu và tín chỉ giảm phát thải được thực hiện dưới cơ chế này có thể được dùng bởi một quốc gia khác báo cáo kết quả thực hiện cam kết NDC của họ.

- Tín chỉ giảm phát thải được tạo ra dưới cơ chế này sẽ không được sử dụng để báo cáo về kết quả đạt được NDC của quốc gia bán bởi đã được sử dụng bởi bên mua.

- Thỏa thuận Paris khuyến cáo các quốc gia phải đảm bảo không tính toán và chi trả giảm phát thải hai lần.

Các vấn đề còn chưa được làm rõ trong Thỏa thuận Paris gây trở ngại cho việc thực hiện chi trả dựa vào kết quả và chuyển quyền Các-bon/chuyển chứng nhận giảm phát thải bao gồm:

- Việc định nghĩa thế nào là "kết quả" giảm thiểu biến đổi khí hậu chưa được hướng dẫn cụ thể. Người ủng hộ cho thị trường Các-bon cho rằng ITMOs là giảm phát thải đã được lượng hóa nhưng trong thực tế còn rất nhiều tranh cãi về vấn đề này.

- Khi báo cáo về kết quả của các hoạt động giảm thiểu được tạo ra từ các dự án trước đây do các cơ quan và các tổ chức quốc tế tài trợ, quốc gia sẽ được tính vào NDC và báo cáo như thế nào.

- Thỏa thuận Paris chưa làm việc các nước đã đạt vượt quá mức cam kết giảm phát thải có thể chuyển nhượng kết quả cho các bên khác hay không.

- Nhiều quốc gia phát triển khi nộp NDC với các cam kết giảm phát thải dựa vào nội lực quốc gia và có thể nâng mức cam kết giảm phát thải nếu có sự hỗ trợ của cộng đồng quốc tế. Trong số các quốc gia này, một số nước đề cập tới việc sử dụng và giữ quyền Các-bon cũng như áp dụng cơ chế thị trường quốc tế để đảm bảo đạt được các mục tiêu giảm phát thải đã được đề cập trong NDC. Tuy nhiên thỏa thuận Paris không phân biệt rõ ràng giữa hai cách tiếp cận này.

- Việc Thỏa Thuận Paris chưa đi đến quyết định cuối cùng liên quan tới việc chuyển giao/chuyển nhượng giảm phát thải giữa các nước có thể dẫn đến việc các ERs đã được chi trả không được tính vào cả nước mua và nước bán trong NDC của họ. 


\subsubsection{Quỹ Các-bon của FCPF}

Quỹ Các-bon của Đối tác lâm nghiệp (FCPF) là một trong những sáng kiến thí điểm chi trả dựa vào kết quả cho giảm phát thải từ các chương trình REDD+ quy mô lớn. Để tiến hành chi trả, người được ủy thác của Quỹ Các-bon sẽ tham gia Thỏa thuận chi trả cho giảm phát thải (ERPAs) được định nghĩa trong hiến chương của FCPF là thỏa thuận quy định "mua lại và chuyển nhượng/chuyển giao giảm phát thải". Theo quy định của FCPF và thỏa thuận ERPAs, giảm phát thải (ERs) và quyền chuyển nhượng bao gồm tất cả quyền, giấy tờ chứng nhận và lợi ích gắn liên với ERs đã chuyên nhượng.

Quỹ Các-bon, thông qua Khung phương pháp của mình, đưa ra các hạn chế nghiêm ngặt đối với việc sử dụng các $\mathrm{ER}$ như sau:

- Bất kỳ $\mathrm{ER}$ nào từ các hoạt động REDD+ trong Chương trình $\mathrm{ER}$ được bán và chuyển cho Quỹ Các-bon sẽ không được sử dụng lại bởi bất kỳ ai để bán, quan hệ công chúng, tuân thủ luật pháp hoặc bất kỳ mục đích nào khác

- ER trong hợp đồng, ER bổ sung, cũng như bất kỳ tấn $\mathrm{CO}_{2}$ e giảm cơ bản nào, chỉ có thể được sử dụng hoặc yêu câu một lần.

- Các điêu khoản trong ERPA sẽ không cho phép quốc gia REDD+ (bên bán) sử dụng ER được tạo ra và bán cho các bên đóng góp vào $\mathrm{Quỹ} \mathrm{Carbon}(\mathrm{CFP})$ để đạt được NDC của mình bởi ER đã được chuyển cho Người được ủy thác. Tuy nhiên, trong cùng một điều khoản có đề cập rằng trong một số trường hợp nhất định, Đơn vị thực hiện chương trình có thể sử dụng các ER để chứng minh sự tuân thủ các mục tiêu giảm thiểu 'trong nước' nếu nhận được sự đông ý của Bên được ủy thác, sau khi tham vấn với các Bên tham gia $Q u y ̃$ Các-bon và nhận được sự đồng ý trước bằng văn bản rõ ràng. Tuy nhiên không rõ NDC sẽ coi đây là đóng góp của quốc gia hay đây sẽ được coi là đóng góp của quốc tế.

Điểm đáng lưu ý là trong hệ thống Quỹ Cácbon cũng có sự phân loại trong cách tiếp cận, đặc biệt giữa các bên đóng góp tài chính chủ lực cho FCPF (Bảng 11). Trong khi thành viên của Nhóm A không nêu rõ việc ERs sẽ được sử dụng như thế nào trong NDC của họ, một số thành viên của Nhóm $\mathrm{B}$ đề cập rõ tới việc sử dụng cơ chế thị trường để đạt được mục tiêu NDC của họ. Việc này ảnh hưởng rất lớn tới các hợp đông và thỏa thuận mua bán giảm phát thải, chuyển chứng nhận quyền phát thải bởi nếu người mua ERPA cần chứng nhận quyên giảm phát thải thì các quốc gia phát triển sẽ không được sử dụng để báo cáo trong thực hiện NDC của họ nữa.

Có thể thấy từ năm 2015 cho tới nay, Úc, BP, Canada, EU, Thụy Điển, TNC đã không đóng góp thêm vào Quỹ Các-bon. Pháp, Mỹ có tăng đóng góp nhưng không đáng kể kể từ 2015. Chỉ có 3 quốc gia duy nhất là Đức, Nauy, UK đã gia tăng đóng góp của mình một cách mạnh mẽ kể từ năm 2015 cho tới nay.

Các thành viên của Nhóm $\mathrm{B}$ (chiếm hơn $90 \%$ đóng góp của $\mathrm{FCPF}$ vào năm 2015) đã thống nhất không sử dụng:

- ER được tạo ra để bán hoặc để thực hiện các quy định trong và ngoài nước của họ, đông thời

- ERs sẽ được hủy bỏ bởi Người được ủy thác sau khi nhận từ các bên thực thi chương trình ERPA.

Ngược lại, các thành viên trong Nhóm $\mathrm{A}$ có quyền tự do sử dụng ER của họ khi nhận được và có thể:

- Hủy ER, tương tự như việc xử lý ER nhận được bởi Nhóm $B$. Việc hủy bỏ cũng có thể được thực hiện bởi CFP sau khi đã nhận được ER trong sổ đăng ký của mình hoặc dựa trên hướng dẫn cho Người được ủy thác,

- Giũ ER và sử dụng nó cho việc hạch toán NDC (ví dụ:

- Giữ ER và sử dụng cho xây dựng hình ảnh, quan hệ công chúng hoặc để tuân thủ hệ thống quy định trong nước (có thể có hoặc không được tính ở cấp quốc gia để đạt được NDC, trừ khi có quy định khác trong ERPA).

- Chuyển giao ER cho các Bên khác, trong trường hợp đó, quyền tính ER đối với NDC được chuyển cho Bên nắm giữ $\mathrm{ER}$, trừ khi có quy định khác trong ERPA.

\subsubsection{Kí kết với Quỹ Khí hậu xanh}

GCF chấp nhận các bản đề xuất ý tưởng dự án và để xuất tài trợ như một phần của chương trình thí điểm cho các khoản thanh toán dựa trên kết quả REDD+. Thí điểm kéo dài 5 năm đánh dấu một cột mốc quan trọng đối với sự hỗ 
Bảng 11. Đóng góp và quan điểm của các cổ đông trong Quỹ Các-bon của FCPF

\begin{tabular}{|c|c|c|c|c|c|}
\hline Nhóm & $\begin{array}{l}\text { Các thành } \\
\text { viên đóng } \\
\text { góp chính } \\
\text { cho FCPF } \\
\text { (CFP) }\end{array}$ & $\begin{array}{l}\text { Quan điểm đề cập trong INDC liên } \\
\text { quan đến cơ chế thị trường quốc tế } \\
\text { năm } 2015\end{array}$ & $\begin{array}{l}\text { Quan điểm đề cập trong } \\
\text { NDC liên quan đến cơ chế thị } \\
\text { trường quốc tế năm } 2020\end{array}$ & $\begin{array}{l}\text { Đóng } \\
\text { góp } \\
2015 \\
\text { (triệu } \\
\text { USD) }\end{array}$ & $\begin{array}{l}\text { Đóng } \\
\text { góp } \\
2020 \\
\text { (triệu } \\
\text { USD) }\end{array}$ \\
\hline \multirow[t]{4}{*}{ Nhóm A } & Úc & $\begin{array}{l}\text { Không đề cập tới việc sử dụng thị } \\
\text { trường quốc tế }\end{array}$ & NA & \multicolumn{2}{|c|}{18.4} \\
\hline & $\mathrm{BP}$ & $\begin{array}{l}\text { Không có INDC, không đề cập tới việc } \\
\text { ERs sẽ được sử dụng ra sao }\end{array}$ & NA & \multicolumn{2}{|l|}{5} \\
\hline & TNC & $\begin{array}{l}\text { Không có INDC, không đề cập tới việc } \\
\text { ERs sẽ được sử dụng ra sao }\end{array}$ & NA & \multicolumn{2}{|l|}{5} \\
\hline & Mỹ & $\begin{array}{l}\text { Không có ý định sử dụng thị trường } \\
\text { quốc tế để đạt được mục tiêu } 2025\end{array}$ & NA & 14 & 18.5 \\
\hline \multirow[t]{7}{*}{ Nhóm B } & Canada & $\begin{array}{l}\text { Có thể sử dụng cơ chế thị trường } \\
\text { quốc tế để đạt mục tiêu 2030, với hệ } \\
\text { thống đảm bảo giảm phát thải được } \\
\text { thẩm định }\end{array}$ & $\begin{array}{l}\text { Sử dụng cơ chế quốc tế để đạt } \\
\text { được mục tiêu phát thải được } \\
\text { kiểm chứng và kiểm toán }\end{array}$ & \multicolumn{2}{|l|}{5} \\
\hline & EU & $\begin{array}{l}\text { Không có nghĩa vụ liên quan đến } \\
\text { giảm thiểu và Tổng thống EU có } \\
\text { quyênn hạn báo cáo thay mặt cho EU } \\
\text { và các thành viên EU vể thành quả } \\
\text { của EU trong việc thực hiện NDC }\end{array}$ & $\begin{array}{l}\text { Phát thải từ ngành hàng không } \\
\text { đang được xem xét bởi luật } \\
\text { pháp của EU và một phần được } \\
\text { quy định bởi cơ chế đánh giá } \\
\text { ICAO. Phát thải từ ngành hàng } \\
\text { không đang được lồng ghép } \\
\text { vào cơ chế EU ETS nhưng EU } \\
\text { ETS mới chỉ áp dụng hạn chế } \\
\text { đối với chuyến bay trong khu } \\
\text { vực EU } \\
\text { Mục tiêu là giảm phát thải 55\% } \\
\text { vào năm } 2030 \text { bằng nguồn tài } \\
\text { chính tự lực và không cần đóng } \\
\text { góp từ tín chỉ quốc tế }\end{array}$ & \multicolumn{2}{|c|}{6.7} \\
\hline & Pháp & \multicolumn{2}{|l|}{ Không có đóng góp từ tín chỉ quốc tế } & 5 & 5.1 \\
\hline & Đức & \multicolumn{2}{|l|}{ Không có đóng góp từ tín chỉ quốc tế } & 125.5 & 321.3 \\
\hline & $\mathrm{Na}$ Uy & $\begin{array}{l}\text { Không sử dụng tín chỉ từ thị trường } \\
\text { quốc tế để đạt được mục tiêu NDC. } \\
\text { Tuy nhiên có thể bao gồm tín chỉ } \\
\text { trong hệ thống EU ETS và thương mại } \\
\text { trong hệ thống của EU }\end{array}$ & $\begin{array}{l}\text { Ghi nhận khung chính sách } \\
\text { biến đổi khí hậu của EU không } \\
\text { cho phép chuyển giao kết quả } \\
\text { giảm phát thải quốc tế ngoài } \\
\text { khối EU. Do vậy đóng góp của } \\
\text { Na Uy vào NDC sẽ là thỏa thuận } \\
\text { giữa EU, Na Uy và Ireland. } \\
\text { Ki vọng sẽ sử dụng cơ chế thị } \\
\text { trường toàn câuu nhưng tránh } \\
\text { báo cáo chônng chéo. Không sử } \\
\text { dụng tín chỉ thị trường quốc tế } \\
\text { để báo cáo kết quả NDC nhưng } \\
\text { sẽ ủng hộ cơ chế thị trường và } \\
\text { sử dụng tín chỉ được tạo ra từ } \\
\text { cơ chế CDM and Jl. }\end{array}$ & 171.3 & 297.1 \\
\hline & Thụy Sĩ & \multicolumn{2}{|c|}{$\begin{array}{l}\text { Đóng góp chủ yếu từ nguồn lực quốc gia và giảm phát thải nội địa và } \\
\text { chỉ một phần dùng tín chỉ Các-bon từ cơ chế toàn cẩu }\end{array}$} & \multicolumn{2}{|c|}{10.8} \\
\hline & UK & \multicolumn{2}{|l|}{ Không có đóng góp từ tín chỉ quốc tế } & 84.5 & 177.6 \\
\hline
\end{tabular}


trợ của Quỹ cho REDD+. Bắt đầu từ tháng 10 năm 2017, GCF đã thí điểm thanh toán dựa trên kết quả REDD+, phù hợp với Khung Warsaw vê REDD+ và các quyết định REDD + khác theo Công ước khung của Liên hợp quốc về biến đổi khí hậu (UNFCCC). Các quốc gia đã hoàn thành hai giai đoạn đầu của REDD+ để có kết quả từ cuối năm 2013 đến cuối năm 2018 đủ điều kiện đăng ký tài trợ giai đoạn 3 thông qua chương trình thí điểm này. Yêu cầu đề xuất này kéo dài từ cuối năm 2017 cho đến cuộc họp Hội đồng quản trị GCF cuối cùng vào năm 2022 (GCF 2020b).
Tại cuộc họp thứ mười tám, Hội đồng đã quyết định phân bổ tới 500 triệu USD cho các đề xuất thí điểm chi trả dựa trên kết quả REDD+. Để có thể nhận được chi trả dựa vào kết quả của GCF, các quốc gia sẽ phải đáp ứng các điều kiện cụ thể (Hộp 3). Tuy nhiên GCF không yêu cầu văn bản chuyển quyền Các-bon mà chỉ yêu cầu quốc gia đảm bảo hệ thống kiểm toán Các-bon minh bạch, không báo cáo hai lần.

Cho tới nay đã có 6 quốc gia nhận được chi trả dựa vào kết quả từ GCF (Bảng 12).

\section{Hộp 3. Điều kiện để nhận được chi trả dựa vào kết quả của GCF}

- Người trình dự án phải là các Đơn vị được GCF công nhận và được nhận được sự đồng thuận, thống nhất từ phía cơ quan đầu mối REDD+ quốc gia và Cơ quan được chỉ định quốc gia (NDA)

- Cần có thư không phản đối từ NDA và sự đồng ý bằng văn bản từ cơ quan / đầu mối quốc gia REDD+ gửi tới Ban thư ký UNFCCC

- Giá trị cố định của giảm phát thải là 5 USD cho mỗi tấn Các-bon dioxide $\left(\mathrm{CO}_{2}\right)$ tương đương với giá trị giảm phát thải hoặc nâng cao trữ lượng Các-bon, được đo lường đầy đủ, báo cáo và xác minh, phù hợp với theo hướng dẫn phương pháp luận của UNFCCC và các yêu cầu của GCF

- Số tiền cuối cùng mà GCF trả cho mỗi quốc gia sẽ được xác định dựa trên: kết quả điểm số đánh giá, tài chính sẵn có cho chương trình thí điểm và sự chấp thuận của Hội đồng quản trị

- Trong chương trình thí điểm, GCF sẽ chấp nhận để xem xét các kết quả từ một phụ lục BUR REDD+ của quốc gia đã được đánh giá về mặt kỹ thuật mà UNFCCC đã thông qua từ ngày 31 tháng 12 năm 2013 (thời điểm áp dụng Khung Warsaw cho REDD+) đến ngày 31 tháng 12 năm 2018

- Chương trình thí điểm REDD+ sẽ được giới hạn ở mức tối đa 500 triệu USD

- Xem xét mức định giá $5 \mathrm{USD} / \mathrm{tCO}$ eq, GCF sẽ có thể trả cho Giảm phát thải 100 triệu $\mathrm{tCO}$ eq (ER). Số tiền thanh toán tối đa cho mỗi quốc gia sẽ được đặt ở mức 30\% tổng khối lượng phải trả ( $\left.30 \mathrm{MtCO}_{2} \mathrm{eq}\right)$ trong suốt quá trình thí điểm

Nguồn: Green Climate Fund (2017)

Bảng 12. 6 quốc gia nhận được chi trả dựa vào kết quả từ Quỹ GCF

\begin{tabular}{llcccc}
\hline & Tên nước & Năm kí & Số tiền kí (triệu USD) & Số tấn CO $_{2}$ mua (triệu tấn) & Tên dự án \\
\hline 1 & Colombia & 2020 & 28.2 & 7.0 & $\mathrm{FP} 134$ \\
2 & Indonesia & 2020 & 103.8 & 20.3 & $\mathrm{FP} 130$ \\
3 & Paraguay & 2019 & 50.0 & 9.8 & $\mathrm{FP} 121$ \\
4 & Chile & 2019 & 63.6 & 12.4 & $\mathrm{FP} 120$ \\
5 & Ecuador & 2019 & 18.6 & 3.6 & $\mathrm{FP} 110$ \\
6 & Brazil & 2019 & 96.5 & 18.8 & $\mathrm{FP} 100$ \\
\hline
\end{tabular}

Nguồn: Nhóm tác giả tự tổng hợp từ số liệu trên website của GCF tính tới ngày 25 tháng 2 năm 2021. 


\subsubsection{Thỏa thuận song phương giữa các nhà tài trợ lớn và các quốc gia đang phát triển}

Nhiều quốc gia cũng tham gia các thỏa thuận song phương chi trả dựa vào kết quả đối với với $\mathrm{Na}$ Uy và Đức nhửng khác với $\mathrm{FCPF}$, các thỏa thuận và chương trình này không yêu cầu mua lại và chuyển nhượng ERs. Chính điều này đã đặt ra nhiều lo ngại liên quan đến rủi ro rằng tính toán và chi trả cho giảm phát thải có thể bị tính trùng lặp nhiều lân.

Trong các nước nhận được chi trả dựa vào kết quả của $\mathrm{Na} \mathrm{Uy}$, Guyana là một trong những nước đâu tiên kí được thỏa thuận với $\mathrm{Na} \mathrm{Uy}$ và đã nhận được tiền thanh toán. Không có quyết định chính thức nào được đưa ra trong Biên bản ghi nhớ giữa $\mathrm{Na}$ Uy và Guyana về tín chỉ Các-bon, chính thức hay cách khác, được chuyển giao giữa Guyana và $\mathrm{Na}$ Uy (Benn và cộng sự 2020). Thỏa thuận này hoàn toàn mang tính tự nguyện, với việc $\mathrm{Na}$ Uy cung cấp tài chính để đổi lại Guyana cung cấp các kết quả được đo lường và được xác minh hoặc đánh giá một cách độc lập. Số tiền $\mathrm{Na} U y$ chi trả đã được sử dụng cho các dự án REDD+ phê duyệt từ trước bao gồm hỗ trợ công nghệ thông tin cho dự án vùng Hinterland, Cơ chế chia sẻ lợi ích Quốc gia, Cấp giấy chứng nhận quyền sử dụng đất cho người dân tộc thiểu số Amerindian, Quỹ Phát triển cho Amerindian, Dự án Phát triển Đất bền vững và Kênh đào Cunha (Benn và cộng sự 2020). 


\section{Kinh nghiệm các quốc gia trên thế giới trong việc xác định và chuyển nhượng quyền Các-bon và giấy chứng nhận giảm phát thải}

Trong phần này, nhóm tác giả tập trung phân tích cơ chế chuyển quyền Các-bon tại các quốc gia đã tham gia kí kết ERPA và ERPD của Quỹ Các-bon và các nước đã nhận được chi trả dựa vào kết quả của Quỹ Khí hậu xanh.
Hiện nay có 47 quốc gia tham gia vào FCPF. Tuy nhiên tính đến thời điểm ngày 25 tháng 2 năm 2021, chỉ có 12 quốc gia (25.53\%) quốc gia đi tới bước kí được Thỏa thuận Chương trình Chi trả giảm phát thải (ERPA) (Hình 4 và Hình 5).

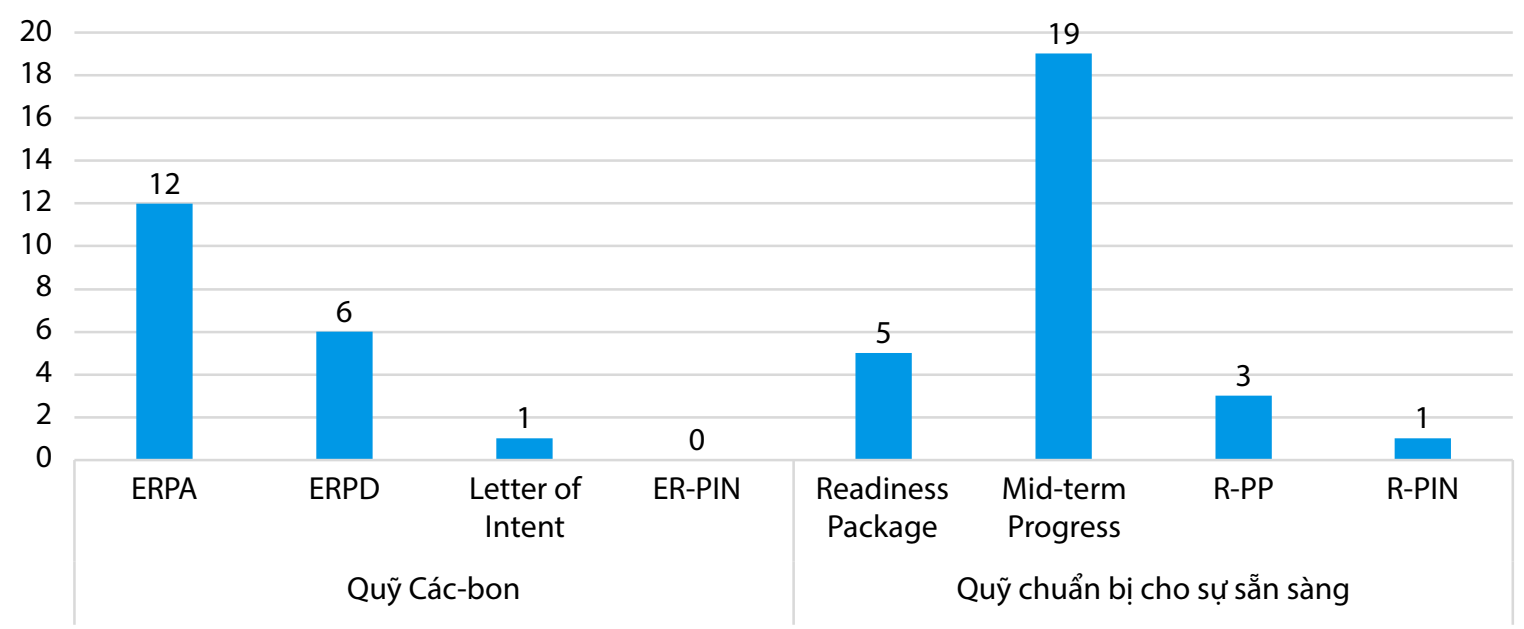

Hình 4. Thực trạng của các nước kí FCPFs tới thời điểm 26 tháng 2 năm 2021

Nguồn: Nhóm tác giả tự tổng hợp từ số liệu trên website của FCPF tính tới ngày 25 tháng 2 năm 2021.

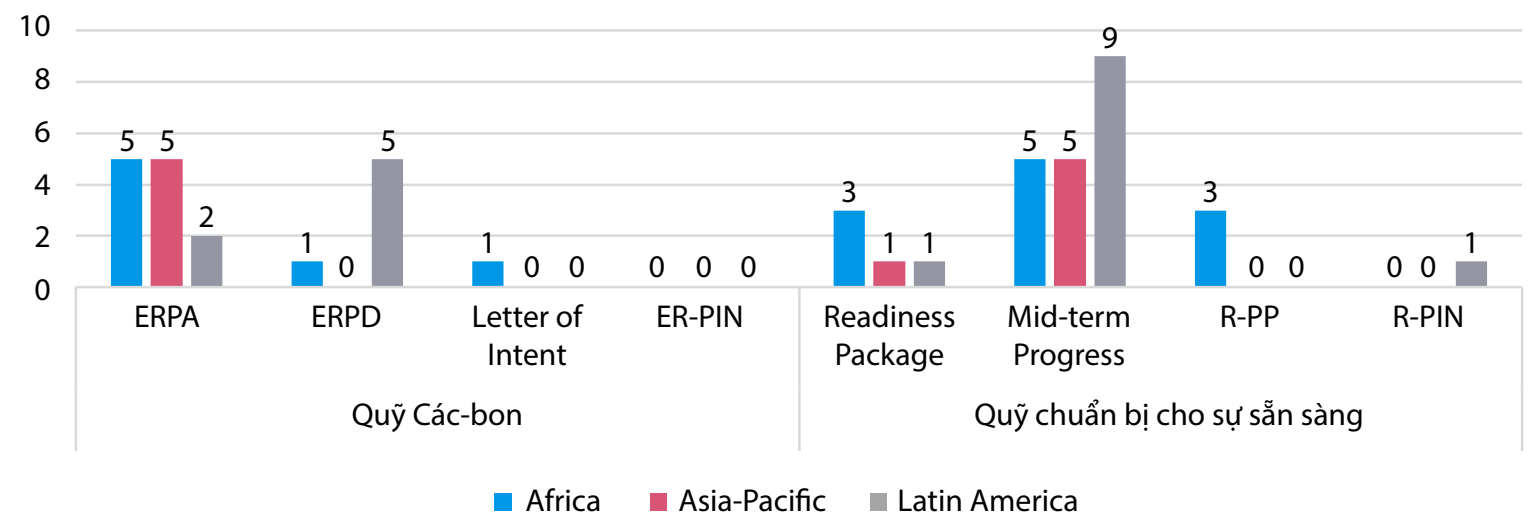

Hình 5. Các nước đã kí FCPF theo khu vực và theo các giai đoạn kí kết của FCPF

Nguồn: Nhóm tác giả tự tổng hợp từ số liệu trên website của FCPF tính tới ngày 25 tháng 2 năm 2021. 


\subsection{Chuyển nhương quyền Các-bon và chứng nhận giảm phát thải tại các nước đã kí ERंPA.}

Bảng 13 cung cấp bức tranh toàn cảnh về 12 nước đã kí ERPA cho tới ngày 26 tháng 2 năm 2021.

Theo hướng dẫn của Quỹ Các-bon trong việc chuyển nhượng quyền Các-bon:

- Thuật ngữ "Quyền sở hữu/giấy chứng nhận đối với ERs" được hiểu là "quyền sở hữu đây đủ về mặt pháp lý và quyền hưởng lợi độc quyền đối với ER được ký hợp đồng theo Thỏa thuận thanh toán giảm phát thải (ERPA)

- Bên được uỷ thác phải đảm bảo các ER do Quỹ Các-bon mua lại không có tranh chấp và quyền sở hữu hợp pháp đối với $\mathrm{ER}$ được chuyển cho Người được ủy thác theo quy định của ERPA.

- Đơn vị thực hiện Chương trình cân chứng minh khả năng chuyển Quyền sở hữu cho các ER trước khi ký ERPA hoặc chậm nhất là trước khi chuyển các $\mathrm{ER}$ cho Quỹ Các-bon thông qua ba lựa chọn. Các giải pháp chứng minh đơn vị thực hiện chương trình có khả năng chuyển quyền các-bon được thể hiện trong Hình 6.
Trong thực tế, Hình 7 và Bảng 14 cho thấy phân lớn các quốc gia đã kí ERPA đều chưa có khung pháp lí cụ thể và rõ ràng nên phân lớn sử dụng các quy định hiện hành để áp dụng vào việc chuyển nhượng quyền Các-bon và quyền giảm phát thải. Có một số quốc gia (ví dụ: Mozambique, Indonesia, Việt Nam) có dự định xây dựng và đưa vào hoạt động các Chính sách và quyết định pháp lí riêng để quy định điều này.

Trừ khi luật trong nước liên kết các dự án Cácbon tự nguyện với các chương trình trong nước hoặc REDD+ quốc gia, các chương trình, các tín chỉ Các-bon được cấp theo tiêu chuẩn tư nhân là tách biệt và độc lập với khung Warsaw Framework và độc lập với các khoản chi trả dựa vào kết quả. Ví dụ: ở Colombia, tín chỉ Các-bon bồi hoàn tránh phá rừng theo tiêu chuẩn Cácbon tự nguyện được coi là đủ điều kiện để đáp ứng các nghĩa vụ tuân thủ theo hệ thống thuế Các-bon của quốc gia. Trong bối cảnh này, các dự án tự nguyện của tư nhân cũng được chính phủ Colombia coi là một phần đóng góp vào NDC theo Thỏa thuận Paris.

Các nước cũng gắn kết chặt chẽ quyền Cácbon với hệ thống chính sách sở hữu đất đai (Bảng 15).

\section{Bảng 13. Các nước đã kí ERPA/FCPF}

\begin{tabular}{|c|c|c|c|c|c|c|}
\hline & Tên nước & $\begin{array}{c}\text { Năm } \\
\text { kí }\end{array}$ & $\begin{array}{l}\text { Số tiền kí } \\
\text { (USD) }\end{array}$ & $\begin{array}{c}\text { Số tấn } \mathrm{CO}_{2} \\
\text { mua }\end{array}$ & $\begin{array}{l}\text { Giá trả cho một tấn } \\
\mathrm{CO}_{2}\end{array}$ & Đại diện cho Chính Phủ kí \\
\hline 1 & Ghana & 2019 & $50,000,000$ & $10,000,000$ & 5 USD & $\begin{array}{l}\text { Bộ Tài Chính và Ủy Ban Lâm } \\
\text { Nghiệp }\end{array}$ \\
\hline 2 & Mozambique & 2019 & $50,000,000$ & $10,000,000$ & 5 USD & Bộ Kinh tế và Tài chính \\
\hline 3 & DRC & 2018 & $55,000,000$ & $11,000,000$ & 5 USD & Bộ Tài chính \\
\hline 4 & Côte d'Ivoire & 2020 & $50,000,000$ & $10,000,000$ & 5 USD & Bộ Kinh tế và Tài chính \\
\hline 5 & Madagascar & 2021 & $50,000,000$ & $10,000,000$ & 5 USD & Bộ Kinh tế và Tài chính \\
\hline 6 & Vietnam & 2020 & $51,500,000$ & $10,300,000$ & 5 USD & $\begin{array}{l}\text { Bộ Nông Nghiệp và Phát } \\
\text { Triển Nông Thôn }\end{array}$ \\
\hline 7 & Fiji & 2021 & $12,500,000$ & $2,500,000$ & 5 USD & Bộ Kinh tế \\
\hline 8 & Indonesia & 2020 & $110,000,000$ & $22,000,000$ & 5 USD & $\begin{array}{l}\text { Bộ Môi trường và Lâm } \\
\text { Nghiệp }\end{array}$ \\
\hline 9 & Lao PDR & 2020 & $42,000,000$ & $8,400,000$ & 5 USD & $\begin{array}{l}\text { Bộ Tài chính và Bộ Nông } \\
\text { Lâm Nghiệp }\end{array}$ \\
\hline 10 & Chile & 2019 & $26,000,000$ & $5,200,000$ & 5 USD & Bộ Tài chính \\
\hline 11 & Costa Rica & 2020 & $60,000,000$ & $12,000,000$ & 5 USD & $\begin{array}{l}\text { Bộ Môi trường và Năng } \\
\text { lượng }\end{array}$ \\
\hline 12 & Nepal & 2021 & $45,000,000$ & $9,000,000$ & 5 USD & Bộ Tài chính \\
\hline
\end{tabular}

Nguồn: Nhóm tác giả tự tổng hợp từ số liệu trên website của FCPF tính tới ngày 25 tháng 2 năm 2021. 


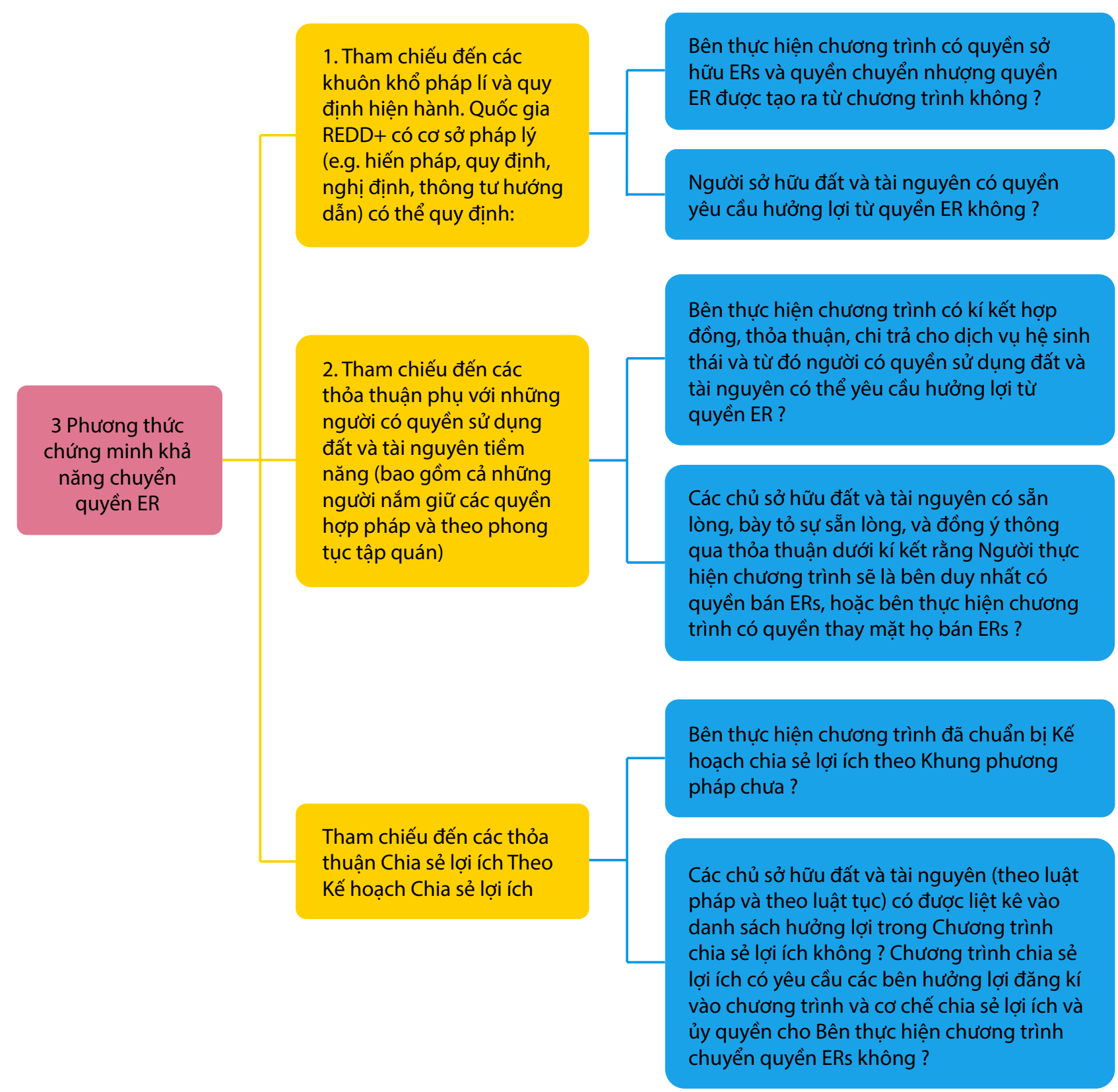

Hình 6. 3 phương thức chính mà các Bên thực thi chương trình có thể chứng minh có khả năng chuyển quyền $E R$

Nguồn: Hướng dẫn của Quỹ FCPF về chuyển quyền Các-bon và chuyển quyền phát thải

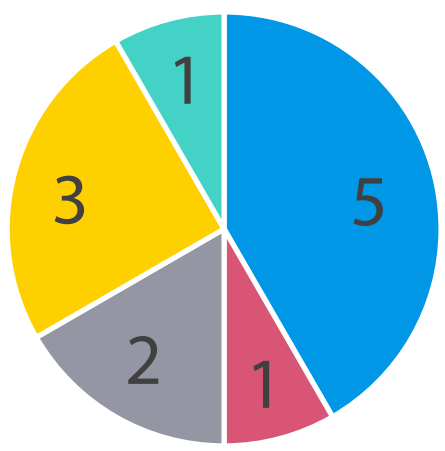

- Tham chiếu tới khuôn khổ pháp lí và quy định hiện hành (Mozambique, Vietnam, Fiji, Costa Rica, Madagascar)

- Tham chiếu tới thỏa thuận phụ với những người có quyền sử dụng đất và tài nguyên tiềm năng (Côte d'Ivoire)

Đề cập tới 2 loại hình: (i) khuôn khổ pháp lí và quy định hiện hành \& (ii) thỏa thuận Chia sẻ lợi ích Theo Kế hoạch Chia sẻ lợi ích (Ghana, Nepal)

Đề cập tới 2 loại hình (i) khuôn khổ pháp lí và quy định hiện hành \& (ii) Các thỏa thuận phụ với những người có quyền sử dụng đất và tài nguyên tiềm năng (DRC, Lao PDR, Chile)

\section{Hình 7. Khung pháp lí tại các nước ERPA trong việc chuyển nhượng quyền Các-bon}

Nguồn: Nhóm tác giả tự tổng hợp từ thỏa thuận ERPA đã kí giữa Quỹ Các-bon và 12 quốc gia 
Bảng 14. Các nước đã kí ERPA/FCPF và hệ thống đăng kí, chuyển nhượng quyền Các-bon của họ

\begin{tabular}{ll}
\hline Nước đã kí ERPA & Đăng kí, chuyển nhượng quyền Các-bon và chứng nhận giảm phát thải \\
\hline 1. Ghana & Chính sách về quyền Các-bon còn chưa rõ ràng và đang được dự kiến hoàn thiện trong thời \\
& gian tới \\
- Đối với luật pháp hiện hành, Chính phủ là người có toàn quyền sở hữu đối với quyền & Các-bon cũng như chuyển giao quyền Các-bon. Tuy nhiên, khi công nhận vai trò của các \\
& cá nhân, cộng đồng và các thực thể khác trong việc giúp tạo ra ERs, Chính phủ công nhận \\
& những đóng góp này thông qua việc chia sẻ lợi ích hợp lý \\
& Do thực tế là ERs không thể chỉ được tạo ra bởi các cá nhân mà chỉ xảy ra thông qua các \\
& hành động tập thể của nhiều bên liên quan và với định nghĩa nêu trên về Quyền đối với ERs, \\
& khung pháp lý hiện hành ở Ghana cho phép việc chuyển giao quyền sở hữu đối với ER
\end{tabular}

2. Mozambique Nghị định của chính phủ ra đời vào năm 2018 quy định:

i. Tất cả các ER được tạo ra ở Mozambique là tài sản của quốc gia

ii. Các chứng nhâan ER có thể được cấp và chuyển giao thông qua các giao dịch tài sản môi trường và tài chính trong nước và quốc tế cũng như có thể được chuyển giao và bồi hoàn trong tương lai dưới các thỏa thuận quốc tế mà Mozambique kí;

iii. Tất cả các ER được tạo ra bởi chương trình và dự án muốn được chứng thực hợp pháp bao gồm cả khả năng thương mại hóa phải đăng kí với Bộ Tài Chính

iv. Bộ Tài chính với tư cách là cơ quan pháp nhân phát hành, quản lí các chứng nhận giảm phát thải chịu trách nhiệm về xác nhận, xác minh giảm phát thải, chuyển giao, giao dịch, xử lí và thu hồi ở cấp quốc gia và quốc tế

3. DRC

- Nghị định thống nhất cấp Bộ trưởng quy định Chính quyền trung ương có chức năng ra quyết định liên quan đến cấu trúc và quy trình cấp chứng chỉ giảm phát thải, trực tiếp nắm giữ và quản lí ERC bởi các chương trình dự án, và có thể hướng dẫn lựa chọn các giải pháp hỗ trợ thương mại ERC cho các chủ sở hữu này mà không cần sự trung gian của chính quyền trung ương. Trong đó cụ thể hơn:

- Bộ Môi trường, Bảo tồn thiên nhiên và du lịch chịu trách nhiệm chính cho việc thực thi REDD+, phê duyệt dự án và định giá REDD+. Bộ này chịu trách nhiệm chính trong việc kí ERPA, chịu mọi trách nhiệm pháp lí liên quan đến hợp đồng với FCPF, việc cấp ERC và chuyển giao hàng hóa cũng như giấy chứng nhận có liên quan.

- Bộ Tài chính phải thông qua quy trình tài chính của ERPA.

- Quyết định của Bộ trưởng liên quan đến việc thông qua các dự án REDD+ hiện đang sửa đổi cũng nhằm mục tiêu:

- Cung cấp quy trình xác định và đăng ký cho các hoạt động REDD+ cấp địa phương không do Chính phủ trực tiếp thực hiện nhưng nằm trong chương trình REDD+ quốc gia

- Tạo một hệ thống đăng ký REDD+ quốc gia liên tục để theo dõi các hoạt động của địa phương và chỉ đạo cấp ERC cho chủ dự án

- Xác định các điều kiện chung cho việc thương mại hóa trực tiếp ERC của các chủ dự án

4. Côte d'Ivoire - Quyền Các-bon được định nghĩa là quyền về hấp thụ hoặc giảm phát thải khí nhà kính được thực hiện bởi các hoạt động REDD+.

- Để định nghĩ quyền Các-bon như một đối tượng của quyền sở hữu (sở hữu công hay tư), cho dù xét về quyền/và/hoặc trách nhiệm gắn với Các-bon, các văn bản qui phạm pháp luật cần làm rõ 2 yếu tố sau:

- Quyền sở hữu đối với các-bon tránh được, giảm bớt hoặc được lưu trữ dưới dạng thực sự có thể nhận dạng được (cụ thể là Giảm phát thải đã được Xác minh);

- Quyền thu được toàn bộ lợi ích phát sinh từ việc chuyển giao quyền sở hữu về giảm phát thải hoặc quyền thanh toán toàn bộ hoặc một phần lợi ích phát sinh từ việc thực hiện giảm phát thải. Trong trường hợp thứ hai, quyền nhận được thanh toán tương đương với tiền thù lao cho một dịch vụ được thực hiện để thực hiện giảm phát thải.

- Có 2 phương thức để hợp pháp hóa quyền Các-bon:

- Coi quyền sở hữu Các-bon không tách biệt với hệ sinh thái hoặc sinh khối mà nó được lưu trữ, hoặc Các-bon tránh được có liên quan đến tác động tích cực của các hoạt động trên mảnh đất được thực hiện và do vậy thuộc về chủ sở hữu đất, chủ sở hữu cây nhưng không phải là sản phẩm có thể chuyển nhượng được 
Bảng 14. Tiếp trang trước

\begin{tabular}{|c|c|}
\hline Nước đã kí ERPA & Đăng kí, chuyển nhượng quyền Các-bon và chứng nhận giảm phát thải \\
\hline & $\begin{array}{l}\text { - Hoặc ngược lại, Các-bon được lưu trữ hoặc được loại bỏ có thể tách khỏi tài nguyên thiên } \\
\text { nhiên. Trong trường hợp này, chủ sở hữu của đất và cây là chủ sở hữu của Các-bon có thể } \\
\text { được mua bán như một sản phẩm chuyển nhượng }\end{array}$ \\
\hline & $\begin{array}{l}\text { - Chính phủ đang xây dựng hướng dẫn để khẳng định chủ quyền sở hữu toàn phần đối với } \\
\text { quyền Các-bon }\end{array}$ \\
\hline 5. Vietnam & Đang xây dựng Quyết định Thủ tướng về chuyển kết quả giảm phát thải \\
\hline 6. Fiji & $\begin{array}{l}\text { Chứng nhận và giao dịch thương mại Các-bon phải được cập nhật và bổ sung vào hệ thống } \\
\text { đăng kí quản lí đất đai hiện hành. Quy trình này đã được làm rõ trong Luật Đất đai và có thể } \\
\text { cập nhật thêm thông qua các quy định bổ sung. }\end{array}$ \\
\hline \multirow[t]{2}{*}{ 7. Indonesia } & $\begin{array}{l}\text { - Chưa có quy định pháp luật về quyền Các-bon (bao gồm giấy chứng nhận cho giảm phát } \\
\text { thải) cũng như làm rõ giữa quyển sở hữu đất (bao gồm quyển sở hữu đất theo tập tục) và } \\
\text { giấy phép sử dụng tài nguyên thiên nhiên cũng như quyền của bên thực hiện chương trình } \\
\text { trong việc sở hữu và chuyển nhượng quyền Các-bon nhưng dự định sẽ có một quyết định } \\
\text { của Tổng thống liên quan đến việc thực hiện NDC. }\end{array}$ \\
\hline & $\begin{array}{l}\text { - Tuy chưa rõ khi nào quyết định của Tổng thống mới được thông qua, các quy định hiện } \\
\text { hành của Indonesia cho phép Bên thực hiện chương trình áp dụng } 2 \text { cơ sở pháp lí: } \\
\text { - Thỏa thuận giữa bên thực hiện chương trình với chính quyền cấp tỉnh tại East Kalimantan } \\
\text { dưới luật về quyền tự quyết của tỉnh cũng như vể sự phối hợp giữa tỉnh, huyện trong việc } \\
\text { thực hiện chương trình hiệu quả } \\
\text { - Lông ghép điều khoản về chứng nhận chuyển nhượng ER trong thỏa thuận cơ chế chia } \\
\text { sẻ lợi ích trong Luật hợp đồng }\end{array}$ \\
\hline
\end{tabular}

8. Lào

- Chứng nhận ERs được định nghĩa là "đầy đủ quyền sở hữu hợp pháp và quyền hưởng lợi và độc quyền đối với ER được ký hợp đồng theo ERPA. Tuy nhiên, định nghĩa chỉ liên quan đến ER mà không bao gồm bất kỳ quyền, danh nghĩa, chứng nhận hoặc lợi ích nào đối với đất đai và lãnh thổ"

- Theo Hiến pháp (2015), Luật đất đai (2003), đất đai và các tài sản từ tài nguyên thiên nhiên (được hiểu là bao gồm cả Các-bon rừng) thuộc quyền sở hữu của toàn dân và Nhà nước đại diện thay mặt để quản lí. Điều này cho phép Bên thực hiện chương trình giảm phát thải được phép đại diện cho Nhà nước, và nhân dân quản lí việc chuyển giao chứng nhận ER

- Luật Lâm nghiệp (2007) quy định rõ rừng tự nhiên thuộc nhân dân và được quản lí bởi nhà nước. Trong khi các cây trồng thuộc về cá nhân và tổ chức trồng cây. Cả Luật Đất Đai và Luật Lâm Nghiệp đều có các điều khoản liên quan đến quyền sử dụng đất và rừng, và thường được hiểu bao gồm cả Các-bon rừng

- Tuy nhiên, ER khác với từng cây đơn lẻ được tạo ra bởi rất nhiều bên có liên quan do chủ sở hữu và người có giấy sử dụng đất và rừng chỉ là một trong số các bên được hưởng lợi và được chi trả từ chương trình ER cũng như trong quá trình chuyển nhượng chứng nhận Các-bon

- Theo các thảo luận tại thời điểm này, quan điểm của Chính phủ là bên thực hiện chương trình ER sẽ thay mặt cho nhà nước và nhân dân là bên ủy thác chuyển giao chứng nhận ERs cho Quỹ Các-bon trong thỏa thuận ERPA. Các tham vấn quốc gia với nhiều bên liên quan sẽ tiếp tục được tiến hành về vấn đề này

9. Chile - Các quy định pháp lí về quyền Các-bon sẽ phải làm rõ:

- Quyền Các-bon (quyền thực sự): bao gồm quyền đối với Các-bon trong sinh khối vật lí được lưu trữ trong đất, cây. Quyền sở hữu đối với Các-bon được lưu trữ trong đất thuộc về chủ sở hữu đất. Quyền giảm phát thải (loại bỏ khí nhà kính) buộc phải gắn liền với so sánh với đường cơ bản. Các hoạt động quản lí rừng như thường lệ sẽ không được tính là giảm phát thải. Quyền giảm phát thải/loại bỏ khí nhà kính bao gồm cả quyền hưởng lợi từ việc giảm phát thải thông qua việc tạo ra các đơn vị Các-bon

- Luật về giảm phát thải (trách nhiệm phải thực hiện theo luật pháp)

- Theo Luật Đất, nếu chương trình giảm phát thải hạn chế quyên của chủ sở hữu đất hoặc chủ đất tình nguyện tham gia cơ chế giảm phát thải thông qua chương trình chi trả dịch vụ môi trường rừng, họ sẽ phải nhận được bồi thường. Trong trường hợp này, tất cả chủ sở hữu đất sẽ chuyển quyền Các-bon hay quyền giảm phát thải cho CONAF thông qua một thỏa thuận. 


\section{Nước đã kí ERPA Đăng kí, chuyển nhượng quyền Các-bon và chứng nhận giảm phát thải}

- Trong trường hợp chủ đất không tham gia chương trình và không được bồi thường hoặc hưởng lợi từ chương trình, chủ rừng có toàn quyền quyết định các hoạt động trên diện tích của họ và tham gia các giao dịch thương mại trên thị trường Các-bon tự nguyện hoặc bắt buộc và do vậy có thể bán thương mại tín chỉ Các-bon và quyền giảm phát thải. Đối với trường hợp này CONAF phải đảm bảo rằng báo cáo giao dịch $E R$ sẽ phải trừ vào hệ thống báo cáo quốc gia để đảm bảo không báo cáo và thương mại hai lần.

- Trong trường hợp chủ sở hữu đất không rõ ràng hoặc thuộc về cộng đồng, một số hoạt động thương mại có thể được cho phép và một số lợi ích nhất định có thể được chia sẻ cho các bên có liên quan.

10. Costa Rica

- Hiện nay chưa có một hệ thống lưu trữ và thu thập thông tin liên quan đến các giao dịch thương mại Các-bon nhưng Văn phòng Biến đổi khí hậu quốc gia đang có kế hoạch xây dựng hệ thống này. Hệ thống này sẽ bao gồm báo cáo minh bạch của tất cả các ngành, trong đó có ngành lâm nghiệp.

- Hiện nay Văn Phòng Biến đổi khí hậu cũng đang thiết kế hệ thống đăng kí giảm phát thải phục vụ cho thị trường Các-bon nội địa và hệ thống này được kì vọng cũng sẽ được áp dụng với REDD+.

- Hiện mỗi cơ quan tham gia vào REDD+ đều phải có hệ thống đăng kí và quản lí chương trình và dự án riêng của mình. Ngành lâm nghiệp đã có hệ thống đăng kí cho chương trình PES được quản lí bởi FONAFIFO với các thông tin trong thỏa thuận bao gồm số liệu đăng kí về tài sản đất đai, quy hoạch địa chính được ghi chính thức tại cơ quan địa chính quốc gia, tên chủ sở hữu, địa điểm hành chính, tổng diện tích tài sản và diện tích có hiệu lực thực hiện thỏa thuận; bản đồ kĩ thuật số của FONAFIFO. Thông tin lữu trự trong hệ thống PES này bao gồm cả các thông tin liên quan đến bể chứa Các-bon, đường cơ bản và hoàn toàn có thể bổ sung các thông tin còn thiếu liên quan đến các dự án REDD+.

- Các lựa chọn mới để hoàn tín chỉ Các-bon được cung cấp thông qua Thị trường các-bon nội địa của Costa. MINAE đang phát triển khuôn khổ quy định và thiết kế những tổ chức nào sẽ chịu trách nhiệm về quy định thị trường nội địa. Costa Rica bảo lưu quyền sử dụng Thị trường Các-bon nội địa như một công cụ để hoàn thành các mục tiêu giảm thiểu, như một sự bổ sung cho các chính sách quốc gia và ngành về giảm phát thải. Bất kỳ đơn vị bồi thường nào được giao dịch ở nước ngoài sẽ được đăng ký trong National Emissions Inventory (Kiểm kê Phát thải Quốc gia) để tránh hạch toán kép.

11. Madagascar - Chứng nhận giảm phát thải $(E R C)$ gắn liền với "quyền Các-bon" và được định nghĩa là quyền được hưởng lợi trong cơ chế PES (Chi trả dịch vụ môi trường)

- Chứng nhận "quyền Các-bon" như một phần của các dịch vụ môi trường.

- Các-bon rừng được coi như tài sản của nhà nước và thuộc toàn quyền quản lí của Bộ Lâm Nghiệp

- Chính phủ có toàn quyền đối với quyền Các-bon liên quan đến giảm phát thải và loại bỏ khí nhà kính. MEEF, đại diện cho chính phủ là cơ quan duy nhất có quyền chuyển nhượng giấy chứng nhận giảm phát thải.

- Luật Môi trường đề cập tới giảm phát thải khí nhà kính hoặc tăng cường hấp thụ Các-bon là một phần của cơ chế Chi trả dịch vụ môi trường. Do vậy, quyền Các-bon được hiểu là quyền hưởng lợi từ việc tạo ra dịch vụ môi trường.

- Với các hoạt động REDD+ sẽ có các đầu tư ban đầu, MEEF, đại diện bởi BNCR sẽ kí một thỏa thuận cam kết $E R$ cho chương trình. Đối với các đầu tư trong tương lai, từng hoạt động REDD+ sẽ có các hợp đồng cụ thể riêng, kí bởi người đầu tư dự án và BNC REDD+

- Đối với các diện tích rừng của nhà nước, chứng nhận Các-bon thuộc về nhà nước

- Đối với diện tích rừng do tư nhân sở hữu, hoặc diện tích rừng được phân bổ cho các bang và chính quyền địa phương quản lí, ước tính chỉ chiếm khoảng dưới $0.1 \%$ diện tích của chương trình, sẽ được thực hiện theo cơ chế kí hợp đồng.

- Đối với các diện tích đất không phải đất lâm nghiệp, chiếm khoảng $30 \%$ diện tích của chương trình, quyền và chứng nhận Các-bon tuân theo Luật tư hữu được định nghĩa trong Luật dân sự. Giảm phát thải liên quan đến REDD+ là một dịch vụ cung cấp lợi ích Các-bon và phi Các-bon cho các bên có liên quan. 
Bảng 14. Tiếp trang trước

\section{Nước đã kí ERPA Đăng kí, chuyển nhượng quyền Các-bon và chứng nhận giảm phát thải}

- Đối với 2 khu bảo tồn thuộc chương trình, chuyển quyền Các-bon sẽ được đăng kí và thông qua theo tiêu chuẩn Các-bon đã thẩm định. Chính phủ sở hữu quyền giảm phát thải được thể hiện rõ trong văn bản và đồng thuận của người quản lí của 2 Khu Bảo Tồn.

- Hai cơ quan quản lí Khu bảo tồn nơi sẽ diễn ra các hoạt động REDD+ kí với Chính Phủ một thỏa thuận. Trong thỏa thuận này, Chính phủ trao toàn quyền thương mại hóa liên quan đến ER cho hai cơ quan này. Thỏa thuận này có thời hạn 5 năm và có thể gia hạn sau 5 năm cũng các điều khoản bổ sung, hủy hợp đồng. Tuy nhiên cả 2 hợp đồng này không có ảnh hưởng gi tới chứng nhận hoặc khả năng chuyển giao chứng nhận mà chỉ là tạo cơ quan hợp pháp có thể tiến hành giao dịch thương mại. Cụ thể hơn:

- Dự án Giảm Phát Thải Các-bon trong Hành lang Khu Bảo Tồn Ankeniheny-Zahamena: Conservation International $(\mathrm{Cl})$ và Chính Phủ đã kí trong điều khoản với Quỹ Khí hậu xanh, trong đó $\mathrm{Cl}$ cam kết không thương mại hóa VCU và đồng ý để Chính phủ có thể bán Giảm phát thải cho Quỹ Các-bon

- Đối với Khu bảo Tồn Makira: Tuy cơ chế chia sẻ lợi ích đang được thảo luận với WCS, nhưng dự án đã cam kết không tạo ra VCUs trong quá trình thực hiện ERPA mà sẽ nhận nguồn tài chính chi trả cho dựa vào kết quả. Nếu VCUs được tạo ra, tổng lượng phát thải bán cho Quỹ Các-bon (bao gồm cả ở vùng đệm) không được vượt quá hạn mức phát thải đã được đề xuất trong ER-P.

- Trong cả 2 mô hình này, 2 Khu Bảo tồn đều rời bỏ mô hình tài chính Các-bon mà lựa chọn mô hình sử dụng các nguồn tài chính khác để đảm bảo chi phí vận hành của mình.

12. Nepal - Chiến lược REDD+ Quốc gia nêu rõ rằng "theo các chế độ sở hữu đất và rừng hiện có, các biện pháp sẽ được thực hiện để đảm bảo quyền Các-bon của các chủ thể có quyền.

- Theo Hiến pháp của Nepal, chính phủ liên bang có thẩm quyền để quản lý các trách nhiệm tài chính liên quan tới dịch vụ Các-bon, cấp quyền và chuyển các chứng nhận ER cho Quỹ Các-bon.

- Mặc dù trữ lượng các-bon rừng là tài sản vô hình được phân loại thuộc thẩm quyền của chính phủ liên bang, nhưng ưu tiên hàng đầu trong Chiến lược REDD+ Quốc gia của Nepal là đảm bảo rằng các cộng đồng đang quản lý rừng được hưởng lợi từ việc bán Các-bon lưu trữ trong rừng dưới quyền sử dụng được làm rõ.

- Quyền các bon chưa được quy định rõ ràng về tiếp cận, quản lý và chuyển nhượng như quyền sở hữu đất. Vi lý do này, và để giảm thiểu nguy cơ xung đột về quyền các-bon, trung tâm REDD+ quốc gia (NRC) sẽ thiết lập một cơ chế "chọn tham gia" theo hợp đồng, được công khai, là điều kiện tiên quyết để chủ đất tư nhân tham gia. Cơ chế hợp đồng sẽ quy định các nghĩa vụ đối với các chủ đất tư nhân trong việc xây dựng và thực hiện một kế hoạch quản lý rừng bền vững và nhân được sự đồng thuận giữa NRC và chủ đất tư nhân dựa trên các điều kiện chính của REDD+, bao gồm nhưng không giới hạn các biện pháp đảm bảo tính lâu dài và giảm thiểu rủi ro dịch chuyển phát thải.

- Chính phủ Liên bang đã bắt đầu đưa ra các quy định về dịch vụ Các-bon trong luật pháp. Lần sửa đổi thứ hai của Luật Lâm nghiệp (1993) vào năm 2016 có. Điều 2 nêu rõ "Dịch vụ Hệ sinh thái" có nghĩa là các dịch vụ và lợi ích sau đây thu được từ các hệ sinh thái: 1. Trữ lượng các-bon 2. Bảo tồn đa dạng sinh học 3. Hệ thống thủy văn 4. Du lịch sinh thái 5. Bất kỳ lợi ích nào khác theo định nghĩa

- Điều khoản liên quan đến quản lý các dịch vụ hệ sinh thái tại Điều 67 (b) nêu rõ: “Việc quản lý, sử dụng và chia sẻ lợi ích của các dịch vụ hệ sinh thái từ rừng sẽ được bố trí theo quy định." Quy chế rừng vẫn chưa được sửa đổi để đưa vào Đạo luật Lâm nghiệp sửa đổi lần thứ hai, bao gồm cả việc xây dựng quản lý, sử dụng và chia sẻ lợi ích của các dịch vụ hệ sinh thái bao gồm giảm phát thải (dịch vụ Các-bon).

Nguồn: FCPF \& chính phủ Ghana (2017), FCPF \& chính phủ Mozambique (2018), FCPF \& chính phủ Cộng Hòa Dân Chủ Congo (2016), FCPF \& chính phủ Côte d'Ivoire (2019), FCPF \& chính phủ Việt Nam (2018), FCPF \& chính phủ Fiji (2019), FCPF \& chính phủ Indonesia (2019), FCPF \& chính phủ Lào PDR (2018), FCPF \& chính phủ Chile (2016), FCPF \& chính phủ Costa Rica (2017), FCPF \& chính phủ Madagascar (2018), FCPF \& chính phủ Nepal (2015). 
Bảng 15. Chính sách quyền Các-bon gắn với sở hữu đất đai

\begin{tabular}{|c|c|}
\hline Hệ thống quản lí đất đai & Chính sách quyền Các-bon gắn với sở hữu đất đai \\
\hline $\begin{array}{l}\text { Tất cả đất rừng đều thuộc } \\
\text { quyền sở hữu của Chính phủ }\end{array}$ & $\begin{array}{l}\text { Quyền các-bon tuân theo luật đất đai và được sở hữu bởi Nhà nước, do vậy REDD+ } \\
\text { ERR thuộc sở hữu của nhà nước và tất cả các tín chỉ đều do chính phủ cấp. Tuy nhiên } \\
\text { quyền giảm và loại bỏ khí nhà kính có thể được chuyển sang cho các công ty tư } \\
\text { nhân và cộng đông qua nhượng quyền và cấp giấy phép (ví dụ: DRC; Mozambique). } \\
\text { - DRC đã thông qua Nghị định vào năm } 2018 \text {, trong đó khẳng định rằng chính } \\
\text { phủ quốc gia với tư cách là chủ sở hữu rừng quốc gia có toàn quyền đối với tất } \\
\text { cả các đơn vị và tín chỉ Các-bon. Tuy nhiên, quyền này có thể được chuyển cho } \\
\text { các nhà phát triển dự án tư nhân thông qua chứng chỉ cấp phép } \\
\text { - Mozambique coi tất cả các quyển Các-bon rừng thuộc quyền sở hữu của chính } \\
\text { phủ quốc gia, mặc dù chúng có thể được chuyển giao cho các nhà phát triển } \\
\text { dự án. } \\
\text { Việt Nam: Luật Bảo vệ Môi trường nêu rõ rằng bất kỳ việc mua bán và chuyển } \\
\text { nhượng quyền nào liên quan đến KNK đều phải được sự chấp thuận của Thủ } \\
\text { tướng Chính phủ. }\end{array}$ \\
\hline
\end{tabular}

Quyền sở hữu rừng thuộc nhà nước hoặc có nhiều chủ sở hữu rừng nhưng quyền sở hữu đối với khối tư nhân là hạn chế

- Quyền Các-bon (ví dụ: Madagascar) hoặc quyền đối với các dịch vụ hệ sinh thái (ví dụ, Ecuador) được tập trung và quản lý ở cấp chính phủ quốc gia

- Trong trường hợp này các dự án tư nhân và các giao dịch liên quan đến ERR không được phép thực hiện

- Ecuador: mặc dù hầu hết tất cả các khu rừng của Ecuador đều do tư nhân hoặc cộng đồng nắm giữ, khoảng một nửa số đất này có các vấn đề về quyền sử dụng đất chưa được giải quyết. Người bản địa quản lý phần lớn đất rừng tại Ecuador. Tuy nhiên, tất cả các dịch vụ hệ sinh thái, bao gồm cả quyền tham gia vào các giao dịch Các-bon, thuộc về nhà nước và cộng đồng không có quyền tham gia vào các giao dịch Các-bon. Theo Hiến pháp của Equador, dịch vụ môi trường không phải là đối tượng có thể sở hữu và do vậy không thể thiết lập mối quan hệ sở hữu và trao đổi

- Madagascar: tất cả các khu rừng, trừ những khu rừng trên đất có chủ quyền là tài sản của nhà nước. Vào năm 2019, ở Madagascar chỉ có 7\% diện tích đất có giấy chứng nhận quyền sử dụng đất. Trong khi nhà nước là chủ sở hữu của tất cả các khu rừng, sự đồng quản lý giữa nhà nước và cộng đồng địa phương đã được thực hiện theo Luật Gestion Locale Sécurisée (Quản lý cục bộ an toàn) năm 1996 (Luật số 96-025). Trong dự thảo nghị định REDD+ đề xuất rằng chính phủ sở hữu tất cả các ERR do các hoạt động REDD+ tạo ra và độc quyền thương mại hóa các quyền đó.

Quyền sở hữu và quản lí rừng được phân bổ cho nhiều đối tượng trong đó có bao gồm cả quyền sở hữu đất đai của cộng đồng và tư nhân
- Quyền các-bon được quy định và áp dụng bởi các quy định cụ thể đặc biệt

- Các tổ chức tư nhân được tự do tham gia vào các dự án thị trường Các-bon tự nguyện nhưng cũng có hạn mức nhất định

- Costa Rica: khoảng một nửa rừng của Costa Rica thuộc sở hữu tư nhân. Hệ thống chi trả DVMTR quốc gia bao phủ khoảng 20\% lãnh thổ quốc gia. Costa Rica quy định các quyền Các-bon trong bối cảnh các dịch vụ chi trả cho hệ sinh thái (PES). Khung pháp lý của Costa Rica thiết lập rằng các chủ sở hữu đất đai cá nhân hoặc tập thể có thể nhận được lợi ích từ việc bán các ERR. Luật PES được gắn với sự công nhận mạnh mẽ các quyền sở hữu tư nhân được phản ánh trong Hiến pháp của Costa Rica. Chủ sở hữu đất có quyền đối với ERR như một phần của quyền được hưởng lợi từ các dịch vụ hệ sinh thái.

- Guatemala: ở Guatemala, quyền sở hữu rừng có liên quan đến quyền sở hữu đất, trừ khi quyền sở hữu đất có quy định khác. Rừng nằm trên đất của bang, thành phố, xã và tư nhân và trong các khu bảo tồn. Rừng tư nhân chiếm khoảng 38\% tổng diện tích rừng, rừng công cộng chiếm khoảng 34\% và phần còn lại là rừng do cộng đồng quản lý. Luật Biến đổi Khí hậu của Guatemala làm rõ rằng "quyền, giấy chứng nhận của các đơn vị giảm phát thải Các-bon" thuộc về các nhà phát triển dự án và những người có quyền quản lý đất đai và do đó, mở ra cánh cửa cho các dự án thị trường Các-bon tư nhân. 
Bảng 15. Tiếp trang trước

\begin{tabular}{|c|c|}
\hline \multirow[t]{2}{*}{ Hệ thống quản lí đất đai } & Chính sách quyền Các-bon gắn với sở hữu đất đai \\
\hline & 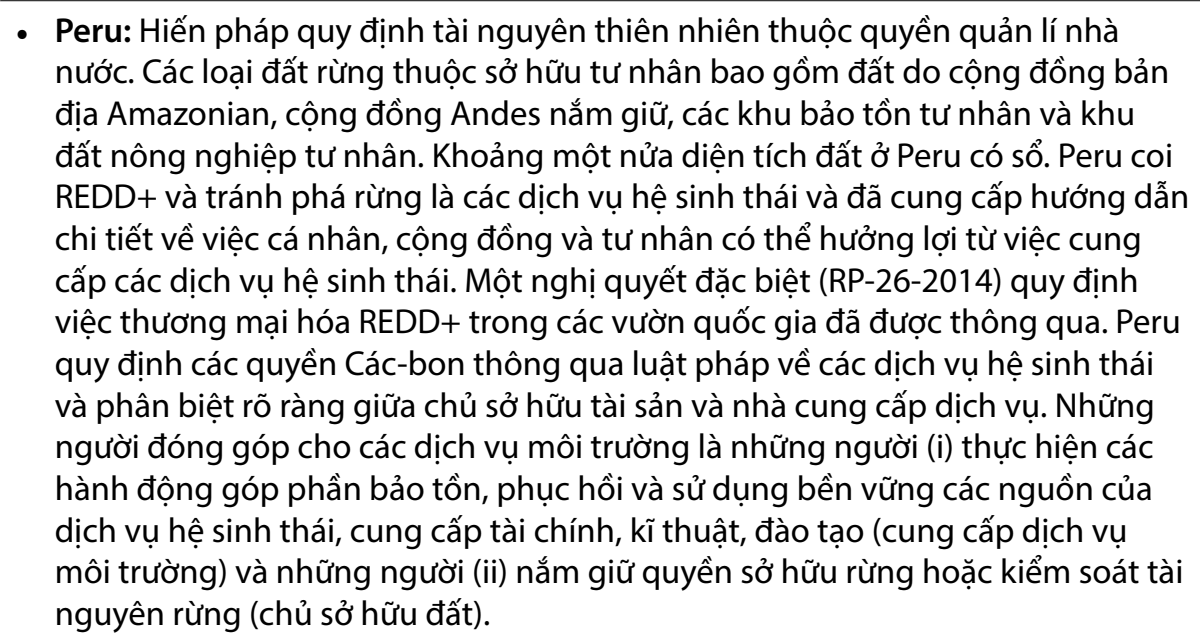 \\
\hline \multirow[t]{3}{*}{$\begin{array}{l}\text { Có nhiều loại hình sở hữu } \\
\text { rừng với những quy định về } \\
\text { quyền sở hữu đất của cộng } \\
\text { đồng và tư nhân được áp } \\
\text { dụng mạnh mẽ và hiệu quả }\end{array}$} & $\begin{array}{l}\text { - Không có quy định cụ thể nào về quyền Các-bon nhưng gắn liền với loại hình } \\
\text { sở hữu đất } \\
\text { - Các tổ chức tư nhân được tự do tham gia vào các dự án thị trường các-bon } \\
\text { tự nguyện trong giới hạn của luật liên quan đến việc sử dụng đất và các biện } \\
\text { pháp bảo đảm an toàn. }\end{array}$ \\
\hline & $\begin{array}{l}\text { - Chile: Chile có ngành lâm nghiệp mạnh và cho phép sở hữu rừng tư nhân. } \\
\text { Quốc gia này không có luật riêng về quyển các-bon nhưng tôn trọng quyền } \\
\text { của chủ sở hữu đất và rừng tham gia vào các dự án giảm phát thải. ở Chile, các } \\
\text { tuyên bố về lợi ích REDD+ tuân theo quyển sở hữu đất đai. Chính phủ công } \\
\text { nhận quyết định của các chủ đất tham gia vào bất kỳ dự án hoặc chương trình } \\
\text { nào liên quan đến việc bồi thường để đổi lấy ERR, cũng như quyền tự do thực } \\
\text { hiện bất kỳ hoạt động nào trên đất của họ, bao gồm các hoạt động bảo tồn và } \\
\text { tái trồng rừng trong giới hạn của luật pháp. Chủ sở hữu cũng có thể tạo ERR } \\
\text { và giao dịch chúng trên thị trường Các-bon tự nguyện hoặc tuân thủ. Trong } \\
\text { trường hợp thứ hai, các cơ quan chức năng quốc gia đảm bảo rằng chủ sở hữu } \\
\text { báo cáo việc bán ERR để chúng có thể được khấu trừ vào tổng lượng giảm phát } \\
\text { thải quốc gia và do đó, tránh nhập hai lần. }\end{array}$ \\
\hline & $\begin{array}{l}\text { - Mexico: Trong tổng diện tích đất rừng, khoảng } 70 \% \text { là tài sản cộng đồng, } 26 \% \\
\text { là tài sản tư nhân (chủ đất quy mô nhỏ), và } 4 \% \text { còn lại là tài sản của chính phủ. } \\
\text { Áp dụng các nguyên tắc chung của luật, Mexico phân biệt giữa quyền hấp thụ } \\
\text { các-bon (loại bỏ) và tránh phát thải do phá rừng (tương đương với việc tránh } \\
\text { một hoạt động bất hợp pháp). Chỉ có dịch vụ hấp thụ Các-bon mới được thực } \\
\text { hiện giao dịch với các tổ chức tư nhân, phân biệt giữa chứng nhận hấp thụ } \\
\text { Các-bon và tránh phát thải. Mức độ mà chính phủ có thể hoặc sẽ tham gia vào } \\
\text { các giao dịch REDD+ ERR vẫn đang được xem xét. }\end{array}$ \\
\hline
\end{tabular}

Nguồn: Streck (2020)

\subsection{Chuyển nhượng quyền Các-bon và chứng nhân giảm phát thải tại các nước ở giai đoạn ERPD}

Tuy chưa đến được giai đoạn kí các thỏa thuận ERPA, Bảng 16 thể hiện định hướng mà các nước đã có ERPD xây dựng chính sách chuyển nhượng quyền Các-bon của mình. Phần lớn các quốc gia đều đang trong quá trình xây dựng chính sách xác định và chuyển quyền các-bon và do vậy cho tới thời điểm này đều áp dụng các luật pháp hiện hành để xác định và chuyển quyền Các-bon trong tương lai. 
Bảng 16. Chuyển nhượng quyền các-bon và chứng nhận giảm phát thải tại các nước ở giai đoạn ERPD

\begin{tabular}{|c|c|}
\hline $\begin{array}{l}\text { 1. Cộng hòa } \\
\text { Congo } \\
\text { (Republic of }\end{array}$ & $\begin{array}{l}\text { - Các quyền liên quan đến Các-bon không được đề cập rõ ràng trong luật pháp của quốc gia, } \\
\text { ngoại trừ gần đây trong bối cảnh luật tố tụng hành chính được quy định trong Nghị định } \\
260 \text { năm } 2015 \text { của Tổng thống và là một phẩn của Bộ luật Lâm nghiệp sửa đổi }\end{array}$ \\
\hline Congo) & $\begin{array}{l}\text { - Theo luật hiện hành, tất cả các quyền liên quan đến chương trình giảm phát thải được xác } \\
\text { định trong một mối quan hệ hợp đồng riêng. ERPA yêu câuu bên bán Các-bon - Chính phủ } \\
\text { Cộng hòa Congo, đại diện bởi Bộ Tài chính -cam kết thực hiện độc quyền có thể bán được } \\
\text { trên thị trường liên quan đến các nỗ lực REDD+ do các bên liên quan REDD+ thực hiện. }\end{array}$ \\
\hline $\begin{array}{l}\text { 2. Dominican } \\
\text { Republic }\end{array}$ & $\begin{array}{l}\text { - Không có bất kỳ quy định pháp luật cụ thể nào về hệ thống tài sản và chuyển giao các-bon } \\
\text { lâm nghiệp và giảm phát thải }\end{array}$ \\
\hline & $\begin{array}{l}\text { - Áp dụng các luật hiện hành bao gồm quyền tài sản truyền thống, quy định về dịch vụ môi } \\
\text { trường, các quy định pháp luật cho phép thừa nhận và liên kết hệ thống sở hữu đất chính } \\
\text { thức và không chính thức với tài sản Các-bon }\end{array}$ \\
\hline & $\begin{array}{l}\text { - Dự kiến xây dựng một kế hoạch về quyền đối với các-bon hoặc giảm phát thải dựa trên việc } \\
\text { tạo ra dịch vụ môi trường (thu giữ các-bon) được thiết lập, thay vì liên kết nó với các quyên } \\
\text { sở hữu chính thức, từ đó đó cho phép đa số nông dân nhỏ và chủ đất phi chính thức cũng } \\
\text { được tiếp cận phân phối lợi ích và tham gia vào Chương trình Giảm phát thải. }\end{array}$ \\
\hline & $\begin{array}{l}\text { - Các quy định trong Bộ luật Dân sự và Hiến pháp Dominica cho phép thiết lập các lựa chọn sau: } \\
\text { - Quyền Các-bon đối với chủ sở hữu đất đồng thời là chủ sở hữu rừng và Các-bon được lưu } \\
\text { trữ bên trong; } \\
\text { - Quyền Các-bon của cộng đồng: áp dụng với các diện tích trống chưa rõ ràng về quyền sở } \\
\text { hữu, vì những tài sản đó không bị ảnh hưởng bởi sở hữu tư nhân } \\
\text { - Quyền sở hữu Các-bon của Nhà nước trong các trường hợp giảm phát thải được tạo ra } \\
\text { trên các vưng đất thuộc sở hữu của Nhà nước. Trong trường hợp này, theo Hiến pháp Nhà } \\
\text { nước có quyền kiểm soát các nguồn tài nguyên thiên nhiên, đồng thơoi thiết lập các giới } \\
\text { hạn và quy định về quản lý và sử rừng và Các-bon rừng. }\end{array}$ \\
\hline & $\begin{array}{l}\text { - Chính sách Chi trả cho Dịch vụ Môi trường quy định “Nhà nước công nhận các dịch vụ môi } \\
\text { trường cung cấp các nguồn tài nguyên thiên nhiên cụ thể và sẽ thiết lập một thủ tục để đưa } \\
\text { các giá trị này vào các tài khoản quốc gia của Dominica”, do đó xác nhận rằng việc thu giữ } \\
\text { các-bon, thông qua việc bảo tôn rừng, sẽ được phân loại trong khung pháp lý của Dominica } \\
\text { như một "dịch vụ” nhằm mục đích tránh phát thải khí cacbonic vào khí quyển. }\end{array}$ \\
\hline
\end{tabular}

3. Guatemala MINFIN chuyển giao quyền sở hữu kết quả giảm phát thải cho Quỹ Các-bon dựa trên các cơ sở sau:

- Tuân thủ Luật Biến đổi khí hậu liên quan đến quyền sở hữu đất và yêu cầu đăng ký tín chỉ Các-bon với Cơ quan đăng ký quốc gia.

- Tôn trọng các chế độ sở hữu đất đai bao gồm sự bảo đảm theo hiến pháp đối với tài sản tư nhân và các quyền của cộng đồng bản địa và địa phương.

4. Mexico Nhà nước có quyền chủ quyền đối với lãnh thổ của mình và có quyền sở hữu mọi tài sản

5. Nicaragua • ở Nicaragua, quyền đối với Các-bon chưa được quy định. Tuy nhiên, Hiến pháp chính trị và luật pháp quốc gia công nhận quyền tài sản và tài nguyên thiên nhiên, đặc biệt là quyền của chủ đất (cá nhân, người sản xuất liên kết riêng lẻ và người bản địa, người Hậu duệ, v.v.), cũng như các quyền cộng đồng của người bản địa.

- Hiến pháp chính trị của Nicaragua, tại Điều 102, công nhận rằng tài nguyên thiên nhiên là di sản quốc gia. Nhà nước có thể ký kết các hợp đồng khai thác hợp lý các nguồn tài nguyên này theo quy trình công khai, minh bạch. Nhà nước chịu trách nhiệm kiểm soát các nguồn tài nguyên thiên nhiên và, thiết lập quy định để quản lý và khai thác của từng đối tượng theo các luật đặc biệt.

- Quyền sở hữu phát thải gắn liền với quyền sở hữu đất đai. Do đó chủ sở hữu đất cũng được hưởng quyền đối với tài nguyên rừng và lợi ích mà, các dịch vụ rừng mang lại. Khi chuyển các khoản giảm phát thải cho Quỹ Các-bon, những lợi ích này cho các chủ sở hữu quyền sẽ được xác định.

- Việc chuyển quyền ER sẽ tính đến các yếu tố sau:

- các quyền khác nhau liên quan đến tài sản chung và tư nhân, trách nhiệm và nghĩa vụ của các bên liên quan, phạm vi của hệ thống giám sát, báo cáo và xác minh, các thủ tục, và quy trình tham vấn ở các vùng lãnh thổ bản địa, tuân thủ Luật Tham gia của công dân và mô hình quản trị dựa trên sự đồng thuận của các bên có liên quan 
Bảng 16. Tiếp trang trước

\begin{tabular}{|c|c|}
\hline & $\begin{array}{l}\text { - Chính phủ có thể chuyển cho Quỹ Các-bon phần ERs đã được ký kết với chủ sở hữu. Việc } \\
\text { chuyển giao ER sẽ phản ánh tỷ lệ phần trăm lãnh thổ (bản địa hoặc tư nhân) nằm dưới } \\
\text { thỏa thuận với MARENA } \\
\text { - trong trường hợp hợp đồng được ký kết với các chủ đất là tư nhân chiếm tới } 80 \% \text { tổng } \\
\text { diện rừng hiện nay thì đơn vị thực hiện Chương trình sẽ yêu cầu chuyển nhượng } 80 \% \text { ER } \\
\text { được tạo ra còn } 20 \% \text { còn lại sẽ được đặt trong một quỹ dự trữ và tìm kiếm giải pháp pháp } \\
\text { lí khác cho phép chuyển quyền sở hữu các giảm phát thải này cho chính phủ }\end{array}$ \\
\hline 6. Peru & 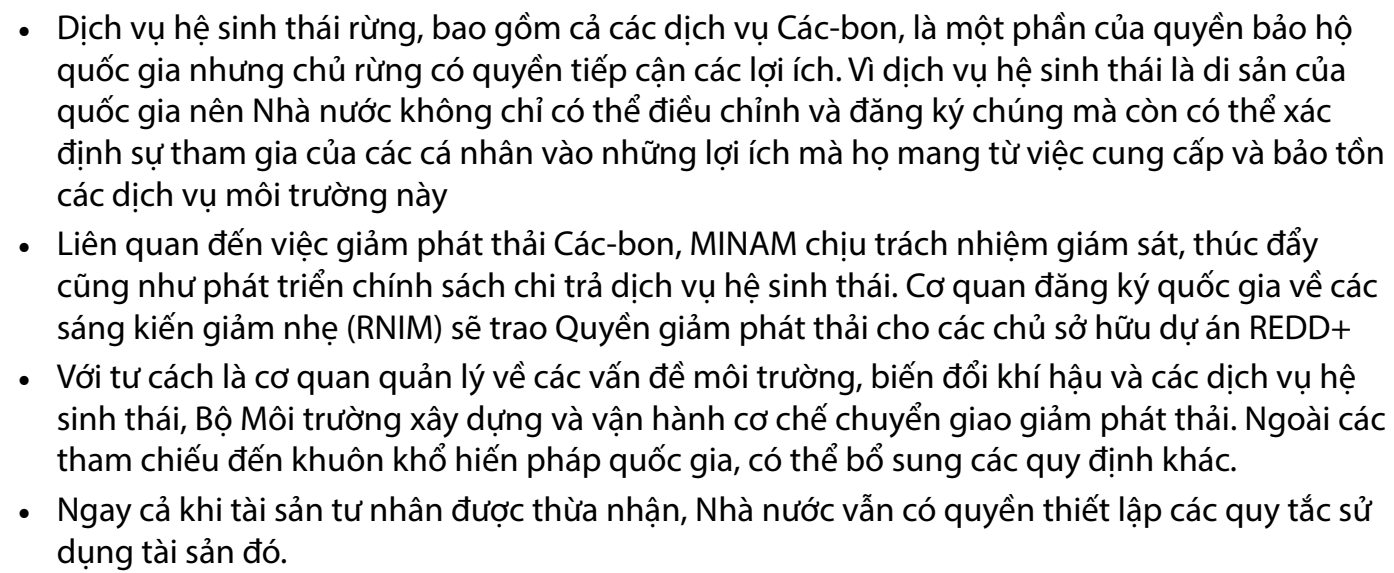 \\
\hline
\end{tabular}

Nguồn: FCPF \& chính phủ Cộng Hòa Congo (2018), FCPF \& chính phủ Dominican Republic (2019), FCPF \& chính phủ Guatemala (2019), FCPF \& chính phủ Mexico (2017), FCPF \& chính phủ Nicaragua (2019), FCPF \& chính phủ Peru (2019).

\subsection{Chuyển nhượng quyền Các-bon và chứng nhận giảm phát thải tại các nước đã nhận được chị trả dựa vào kết quả của Quỹ Ǩhí hậu xanh (GCF)}

Mặc dù khi nhận chi trả dựa vào kết quả, GCF không yêu câu các quốc gia chuyển quyền sở hữu Các-bon hay kết quả giảm phát thải cho mình, 6 quốc gia nhận được chi trả dựa vào kết quả của GCF phải chứng minh trong văn kiện dự án rằng các dự án này có hệ thống kiểm toán Các-bon minh bạch và không được báo cáo chồng chéo về kết quả giảm phát thải hai lần. Do vậy, trong các kiện dự án đã được phê duyệt, các quốc gia này đều thông báo về luật pháp liên quan đến chuyển quyền Các-bon như một đảm bảo pháp lí vững chắc cho điều này. Hình 8 và Bảng 17 trình bày rõ hơn cách tiếp cận mà họ đã áp dụng trong việc chuyển nhượng quyền Các-bon.

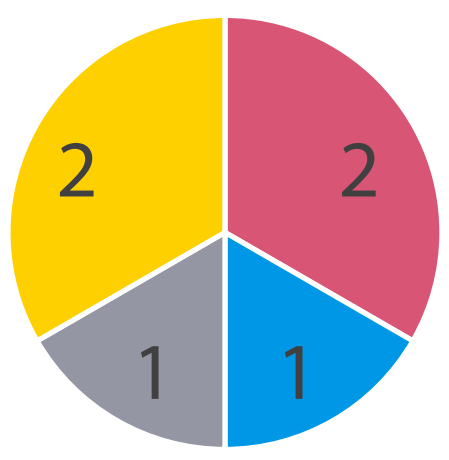

- Tham chiếu đến khuôn khổ pháp lí và quy định hiện hành (Brazil, Colombia)

- Tham chiếu đến 2 hình thức : (i) Các khuôn khổ pháp lí và quy định hiện hành \& (ii) Các thỏa thuận phụ với những người có quyền sử dụng đất và tài nguyên tiềm năng (Chile)

- Đề cập tới cả 3 loại hình: (i) Các khuôn khổ pháp lí và quy định hiện hành, (ii) Các thỏa thuận phụ với những người có quyền sử dụng đất và tài nguyên tiềm năng \& (iii) Các thỏa thuận Chia sẻ lợi ích Theo Kế hoạch Chia sẻ lợi ích (Indonesia)

- Chưa xác định (Paraguay, Ecuador)

Hình 8. Các hình thức xây dựng quyền chuyền các-bon của các quốc gia 
Bảng 17. Chuyển quyền các-bon và giảm phát thải tại các nước đã nhận được chi trả dựa vào kết quả của quỹ khí hậu xanh

\begin{tabular}{|c|c|}
\hline Nước & Chuyển quyền Các-bon và giảm phát thải \\
\hline \multirow[t]{9}{*}{ 1. Brazil } & 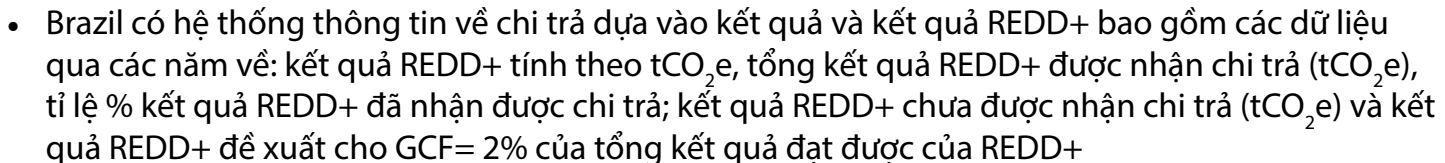 \\
\hline & $\begin{array}{l}\text { - Các biện pháp đảm bảo kết quả được trả bởi GCF sẽ không được chuyển nhượng hoặc đề xuất } \\
\text { cho chi trả trong tương lai đã được thiết lập. }\end{array}$ \\
\hline & $\begin{array}{l}\text { - Ban điều hành REDD+ quốc gia (CONAREDD+) sẽ chịu trách nhiệm ủy quyền cho các bên có liên } \\
\text { quan trong việc tiếp cận và nhận chi trả dựa vào kết quả của Brazil. }\end{array}$ \\
\hline & $\begin{array}{l}\text { - Cho tới nay chỉ có } 4 \text { cơ quan được nhận và tiếp cận với chi trả dựa vào kết quả, bao gồm Bang } \\
\text { Acre, Bang Mato Grosso, MMA và Ngân hàng phát triển Brazil (BNDES)/ Amazon Fund. }\end{array}$ \\
\hline & $\begin{array}{l}\text { - Kết quả nhận chi trả này sẽ được đưa vào hệ thống thông tin REDD+ và không nhận được bất cứ } \\
\text { chi trả nào khác trong tương lai và Ban thư kí của UNFCCC cũng được thông báo về chi trả này } \\
\text { thông qua Lima REDD+ information Hub. }\end{array}$ \\
\hline & $\begin{array}{l}\text { - Bởi không còn có chuyển giao kết quả này cho bất cứ đối tượng nào trong tương lai nên không } \\
\text { cần truy xuất thông qua việc tạo ra các series số Các-bon mà Chính phủ sẽ trừ thẳng lượng Các- } \\
\text { bon đã được trả trong tổng số kết quả REDD+ có thể tạo ra trong năm đó. }\end{array}$ \\
\hline & $\begin{array}{l}\text { - Quỹ Amazon cũng cung cấp thông tin về các nhà tài trợ cho Quỹ từ năm } 2009 \text { và BNDES ghi nhận các } \\
\text { đóng góp của các nhà tài trợ này nhưng các ghi nhận và chứng nhận này không mang tính thỏa thuận và } \\
\text { không thể chuyển giao hoặc bao gồm các quyền sở hữu hoặc liên quan đến bất cứ tín chỉ Các-bon nào. }\end{array}$ \\
\hline & $\begin{array}{l}\text { - Trong tương lai, tất cả các chứng nhận về chi trả dựa vào kết quả của REDD+ mà Brazil đạt được sẽ } \\
\text { được cấp bởi Ban thư kí của CONAREDD+ là MMA. Quy định của Brazil (Nghị định do Bang thông qua) } \\
\text { cũng nêu rõ các chứng nhận chi trả dựa vào kết quả của REDD+ không được sử dưng, trực tiếp hoặc } \\
\text { gián tiếp để báo cáo về thực thi cam kết của nước khác trong kết quả giảm phát thải với UNFCCC. }\end{array}$ \\
\hline & $\begin{array}{l}\text { - Ngoài ra, NDC của Brazil khẳng định rằng bất kì chuyển giao hay chuyển nhượng đơn vị//tín chỉ } \\
\text { từ kết quả của việc giảm phát thải đạt được trên lãnh thổ của Brazil phải được báo cáo trước và } \\
\text { thông qua bởi Chính quyển bang. Brazil sẽ không công nhận đơn vị đâuu ra và cơ chế của giảm } \\
\text { phát thải của các bên khác trên lãnh thổ của Brazil ngoài Kyotol Protocol và Thỏa Thuận Paris. }\end{array}$ \\
\hline \multirow[t]{5}{*}{ 2. Chile } & $\begin{array}{l}\text { - Giảm phát thải được đệ trình cho GCF không phải là hệ thống công khai mà sử dụng một hệ } \\
\text { thống truy xuất xây dựng bởi một liên minh tư vấn cho CONAF do FCPF tài trợ. Hệ thống này } \\
\text { đang được thử nghiệm và kì vọng sẽ trở thành cổng thông tin công khai }\end{array}$ \\
\hline & $\begin{array}{l}\text { - ER đạt được ở Chile cũng như từ hỗ trợ của GCF sẽ được đăng kí trên công thông tin REDD+ Lima } \\
\text { của UNFCCC }\end{array}$ \\
\hline & $\begin{array}{l}\text { - Trong khi hệ thống truy xuất đang được xây dựng, Chile áp dụng hệ thống tạm thời truy xuất } \\
\text { các đăng kí công khai về tiêu chuẩn Các-bon rừng hiện có (ví dụ: Verified Carbon Standard, Gold } \\
\text { Standard, Plan Vivo, Climate Action Reserve, American Carbon Registry). Bất kì dự án REDD+ nào } \\
\text { được tìm thấy trên hệ thống đăng kí này sẽ được upload lên hệ thống database ngay tránh việc } \\
\text { chồng chéo trong việc báo cáo và nhận chi trả hai lần trong tương lai }\end{array}$ \\
\hline & $\begin{array}{l}\text { - CONAF là cơ quan nhà nước có thẩm quyền và chức năng chuyển quyền ERs, như trong ERPA đã } \\
\text { thông qua }\end{array}$ \\
\hline & $\begin{array}{l}\text { - Bộ Tài sản quốc gia có hướng dẫn rằng CONAF có thể tiến hành ERPA và thừa nhận pháp lí về vai } \\
\text { trò của của đơn vị này trong chuyển giao quyê̂n sở hữu Các-bon cho Quỹ Các-bon }\end{array}$ \\
\hline
\end{tabular}

3. Colombia Bộ Môi trường và Phát Triển Bền Vững (MADS) là cơ quan quốc gia chịu trách nhiệm về quản lí môi trường và tài nguyên thiên nhiên và do vậy đại diện cho Chính phủ về quyền hạn và trách nhiệm quản lí chứng nhận ER

- Nghị quyết 1447/2018 của MADS quy định về hệ thống MRV quốc gia và Hệ thống quốc gia đăng kí giảm phát thải khí nhà kính (RENARE) áp dụng cho các chương trình dự án hoặc các bên có quan tâm trong việc đăng kí các chương trình đóng góp vào nỗ lực giảm phát thải quốc gia

- RENARE bao gồm hệ thống và quy trình đăng ký quốc gia về các chương trình và dự án REDD+ cũng như các quy định dành cho chủ sở hữu quyền chi trả dựa vào kết quả. Các dự án phải cung cấp các thông tin sau ở mỗi giai đoạn của dự án: i) xác định các lĩnh vực và địa điểm kết quả đạt được; ii) đối tượng đủ điều kiện nhận thanh toán; iii) năm khi ER được tạo ra; iv) nguồn của các khoản thanh toán dựa trên kết quả nhận được; và v) số nhận dạng của $E R$ 
Bảng 17. Tiếp trang trước

\begin{tabular}{ll}
\hline Nước & Chuyển quyền Các-bon và giảm phát thải \\
\hline • & MADS có quyền lựa chọn chương trình dự án hay sáng kiến nào sẽ được nhận chi trả dựa vào kết \\
& quả thông qua việc đăng kí vào RENARE kết quả giảm phát thải đạt được trong Amazon biome và \\
& giảm phát thải được chứng thực và công nhận bởi MADS sẽ không bị tranh chấp bởi các bên khác \\
- Trong khi RENARE đang mới ở bước đầu xây dựng, Colombia sử dụng một hệ thống đăng kí tạm \\
thời được xây dựng để báo cáo kết quả giảm ERs và để nhận chi trả \\
- Colombia sẽ trừ từng đơn vị giảm phát thải đã được chi trả bởi chương trình REM như đóng góp \\
quốc gia. Các đơn vị đóng góp của quốc gia cũng phải đăng kí để tránh chồng chéo
\end{tabular}

4. Indonesia - Khung pháp lí cho quyền Các-bon rừng tại Indonesia vẫn đang được phát triển

- Trong khi Quy định của Bộ Lâm nghiệp về Quản lý Các-bon rừng ('Quy định số 20 2012') cũng như Quy định số P.30 / Menhut- REDD-plus RBP đề xuất lên Quỹ Khí Hậu Xanh chưa định nghĩa rõ ràng quyền đối với các-bon, các nhà quản lý các-bon và người có giấy phép theo các quy định này được trao quyền thương mại Các-bon.

- Các nguyên tắc cơ bản để thực hiện các hoạt động liên quan đến 'quản lý Các-bon rừng' bao gồm các hoạt động lưu trữ và / hoặc hấp thụ Các-bon và đưa ra các tiêu chí để được cấp giấy phép quản lý các-bon rừng đối với rừng thuộc sở hữu nhà nước là rừng sản xuất hoặc rừng phòng hộ. Theo quy định này, các nhà quản lý các-bon rừng có quyền mua bán Các-bon rừng mà họ quản lý. Quyền kinh doanh như vậy có thể được hiểu là trao quyền một cách ngầm định đối với cácbon rừng cho những tổ chức thực hiện quản lý Các-bon rừng.

- Đối với việc thiết lập quyền Các-bon rừng, Quy chế đưa ra ba tiêu chí để 'quản lý các-bon rừng': (i) cho phép Bộ Môi trường và Lâm nghiệp quản lý Các-bon rừng (ii) phân định rõ ai là người quản lí Các-bon, bao gồm các cơ quan chính phủ, doanh nghiệp (nhà nước, khu vực hoặc tư nhân), hợp tác xã hoặc xã hội; và (iii) khu vực rõ ràng

- Các kết quả cung cấp cho GCF đạt được thông qua các sáng kiến lập pháp và quy định do chính quyền trung ương thực hiện với tư cách là cơ quan quản lý chính về Các-bon rừng

- Khi quyền sử dụng đất được xác định rõ ràng, chủ sở hữu đất có thể gửi yêu cầu cấp phép quản lý các-bon rừng lên Bộ Môi trường và Lâm nghiệp và đăng ký hoạt động của họ tại hệ thống đăng kí quốc gia (SRN) theo Quy định số 202012 và REIP 2017

- Quyền giảm phát thải cũng có thể được thiết lập thông qua các giấy phép, dưới dạng giấy phép kinh doanh để sử dụng hấp thụ Các-bon trong rừng sản xuất và rừng được bảo vệ cũng như giấy phép kinh doanh để sử dụng lưu trữ Các-bon hoặc thông qua các thỏa thuận theo hợp đồng, ví dụ như thông qua các quan hệ đối tác lâm nghiệp hoặc các quan hệ đối tác tư nhân.

- Để tránh tranh chấp về quyền giảm phát thải, Indoneisa đã:

- Xây dựng hệ thống đăng kí quốc gia cung cấp tất cả thông tin về giao dịch Các-bon rừng

- Giảm phát thải bởi các doanh nghiệp hay cấp địa phương thường nằm ngoài khu vực dự án REDD+ và thường không được tính vào kết quả REDD+

- Ban hành một thông tư vào tháng 7 năm 2017, trong đó thông báo rằng cho đến khi có Quy định về Tín chỉ Các-bon sẽ không có hợp đồng mới hoặc giao dịch kinh doanh đối với các giao dịch tín chỉ Các-bon của những người có giấy phép. Hơn nữa, những người có giấy phép hiện tại phải báo cáo với Bộ Môi trường và Lâm nghiệp mọi kế hoạch kinh doanh tín chỉ Các-bon hoặc bất kỳ hợp đồng hiện có

- Dù đã có các quy định hiện hành và các biện pháp bảo vệ bổ sung được thực hiện, nếu có các tuyên bố cạnh tranh được đưa ra bởi một bên thứ ba, Chính phủ sẽ hoàn toàn chịu trách nhiệm và thực hiện tất cả các biện pháp pháp lý cần thiết

5. Paraguay Hiện kết quả trả bởi GCF đang trong quá trình đăng kí vào hệ thống đăng kí các hoạt động giảm thiểu biến đổi quốc gia bao gồm cả các kết quả REDD+ đồng thời được công bố trong cổng thông tin "Lima REDD+ Information Hub"

- Đã có nhiều sáng kiến tài chính như miễn trừ thuế bất động sản cho hoạt động trồng rừng, hoàn lại thuế thu nhập nếu quỹ được đầu tư vào trồng rừng và miễn thuế cho các vật dụng và công cụ cần thiết cho các hoạt động tái trồng rừng

- Chính phủ, thông qua MADES và Ủy Ban Biến đổi khí hậu đang trong quá trình bàn thảo xây dựng hệ thống đăng kí các hoạt động giảm thiểu quốc gia cho các ngành và cũng đã công bố hệ thống đăng kí REDD+ online 


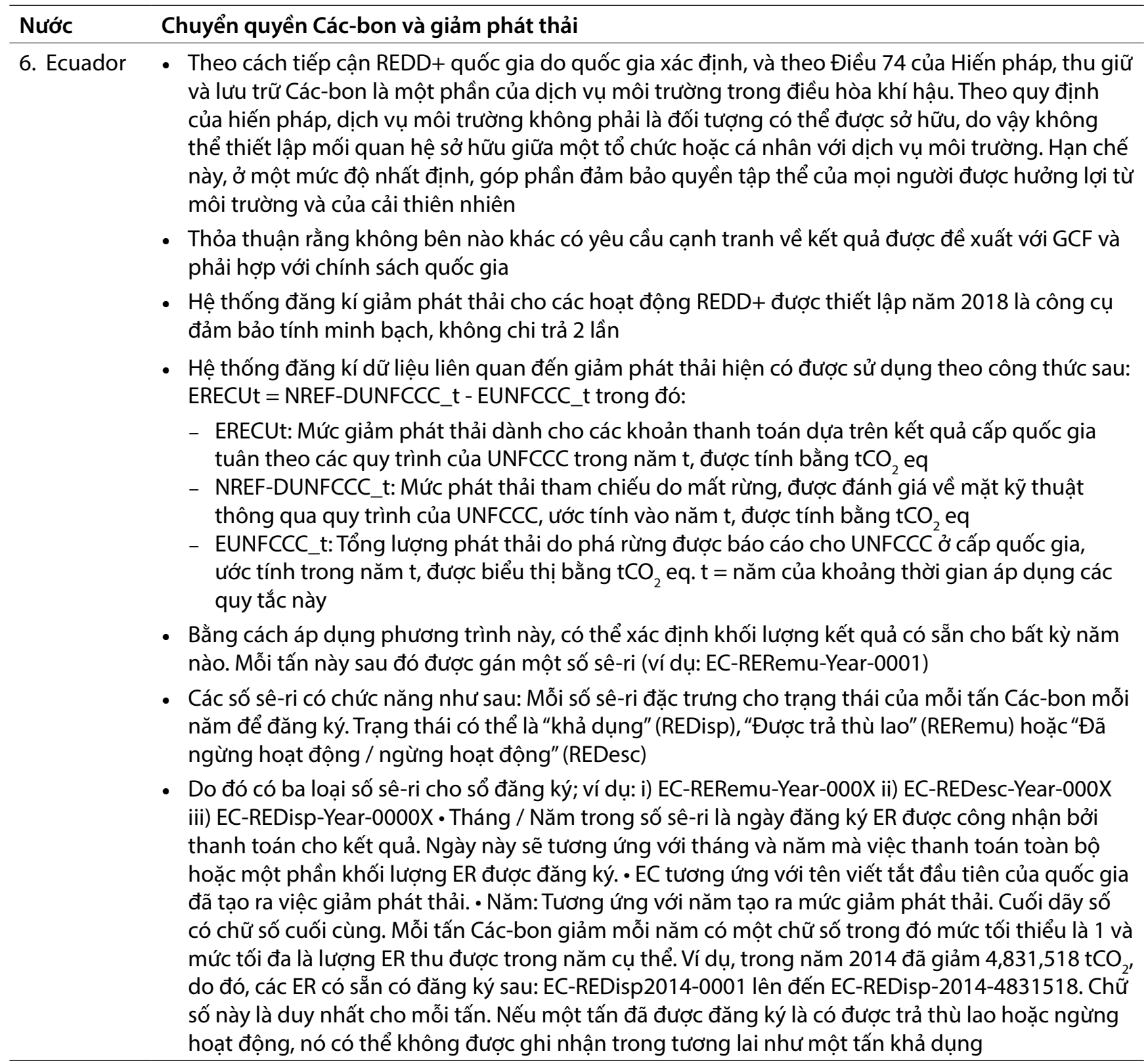

Nguồn: GCF (2019a); GCF (2019b); GCF (2019c); GCF (2019d); GCF (2020c); GCF (2020d) 


\section{Thảo luận và đề xuất chính sách}

Báo cáo này cho thấy việc xây dựng hệ thống pháp lí vê định nghĩa và chuyển nhượng quyền Các-bon/quyền phát thải là vấn đề mới không chỉ tại Việt Nam mà còn tại nhiều quốc gia trên thế giới. Quá trình xây dựng chính sách liên quan đến vấn đề này thường kéo dài và phụ thuộc vào định hướng phát triển của quốc gia, năng lực của các bên có liên quan cũng như nguôn lực tài chính hiện có. Trong bối cảnh toàn cầu hóa hiện nay, một số vấn mà Việt Nam cần xem xét trong quá trình xây dựng chính sách chuyển quyền Các-bon tại Việt Nam bao gồm:

\subsection{Việt Nam nên hướng tới thi trường Các-bon bắt buộc hay thị trường Các-bon tự nguyện ?}

Rất nhiều câu hỏi được đặt ra bởi các bên có liên quan về vấn đề Việt Nam nên ưu tiên phát triển thị trường Các-bon tự nguyện hay thị trường Các-bon bắt buộc ? Báo cáo này cho thấy, trong tương lai các quốc gia đều phải phát triển và hướng tới cả hai thị trường này. Việc chuẩn bị và hướng tới thị trường Các-bon tự nguyện sẽ giúp Việt Nam hoàn thiện hệ thống quản lí hành chính cũng như bán được Các-bon trong khi các thỏa thuận quốc tế về thị trường bắt buộc còn đang được thảo luận chưa đi đến thống nhất. Ngoài ra, như đã phân tích trong báo cáo này, các dự án của ngành lâm nghiệp liên quan trông mới rừng, tái trồng rừng và giảm phát thải từ phá rừng và suy thoái rừng thường dễ dàng thực hiện hơn, có nhu câu lớn hơn và có nhiêu người mua hơn trong thị trường Các-bon tự nguyện. Tuy nhiên tham gia vào thị trường bắt buộc là yếu tố quan trọng để Việt Nam và các nước đạt được mục tiêu đề ra của Thỏa Thuận Paris cũng như giúp Việt Nam tiếp cận với nguôn tài chính quốc tế.

Nếu như việc tham gia vào thị trường tự nguyện đòi hỏi các bên có liên quan (cả trong và ngoài nước) phải đảm bảo đáp ứng các tiêu chuẩn Các-bon tự nguyện tùy vào bên mua là ai thì tham gia vào thị trường Các-bon bắt buộc đòi hỏi sự nhất quán về phương pháp và quy trình quốc tế thông qua bởi các bên tham gia thỏa thuận Paris, đồng thời xây dựng quy trình chính sách mới như các nước đã xây dựng với thị trường Các-bon nội địa bắt buộc của mình.

Trong khi chờ quốc tế thông nhất về luật chơi của Điều khoản 6 trong Thỏa thuận Paris, Việt Nam nên ưu tiên phát triển dự án và kêu gọi đâu tư vào các dự án hướng tới thị trường Cácbon tự nguyện.

Ngoài ra Việt Nam cân xem xét để hỗ trợ cả hai mô hình hàng hóa Các-bon: hạn mức phát thải và bồi hoàn Các-bon bởi mỗi loại hàng hóa này đều có lượng lớn người mua tiềm năng đang tìm kiếm trên thị trường trong và ngoài nước.

\subsection{Kết nối giữa thị trường Các- bon nội địa và thị trường Các-bon quốc tế ?}

Cơ chế Chi trả dịch vụ môi trường rừng (PFES) cho Các-bon rừng hiện nay tại Việt Nam thể hiện tiềm năng và cam kết chính trị trong việc vận hành cơ chế Các-bon nội địa, trong đó có sản phẩm Các-bon rừng do ngành lâm nghiệp tạo ra. Các chương trình và dự án hiện nay liên quan đến cơ chế Giảm Phát Thải từ Phá rừng và suy thoái rừng $(\mathrm{REDD}+)$ cũng cho thấy Việt Nam có quan tâm và định hướng tới thị trường Các-bon quốc tế. Vậy kết nối giữa thị trường Các-bon quốc tế và thị trường Các-bon nội địa này như thế nào ? Có sự khác nhau nào giữa hai thị trường này không ? Một số vấn đề mà Việt Nam cần xem xét trong quá trình xây dựng chính sách Các-bon rừng nội địa cũng như tiến vào thị trường Cácbon quốc tế là: 


\subsubsection{Xem xét kết hợp và đa dạng hóa các công cụ chính sách để thành lập thị trường Các-bon nội địa}

Như báo cáo này đã chỉ ra, các quốc gia trên thế giới xây dựng thị trường Các-bon nội địa của mình thông qua hình thức: (i) áp dụng thuế Các-bon, (ii) xây dựng cơ chế thương mại phát thải dựa vào việc cấp hạn mức phát thải cho các ngành; (iii) chi trả dịch vụ môi trường Các-bon rừng. Mặc dù hiện nay Việt Nam đang hướng tới giải pháp thứ 3 - PFES- tuy nhiên cũng có thể xem xét bổ sung thêm hai giải pháp còn lại. Một trong những ưu điểm của việc xem xét hai giải pháp thuế Các-bon hoặc xây dựng cơ chế thương mại phát thải hoặc kết hợp cả hai giải pháp này như nhiêu nước ở phần trên đã lựa chọn là Việt Nam có thể áp dụng các tiêu chuẩn Các-bon của thị trường Các-bon quốc tế vào thị trường Các-bon nội địa của mình. Cũng nhờ đó, khi muốn bán tín chỉ Các-bon tạo được trong thị trường Cácbon nội địa của mình, Việt Nam sẽ dễ dàng bán được sản phẩm hiện có hơn vì sản phẩm này cũng đã đáp ứng yêu câu của quốc tế.

\subsubsection{Hoàn thiện kết nối giữa thị trường quốc tế và thị trường nội địa}

Việc vận hành PFES dự kiến cho dịch vụ Cácbon nội địa hiện nay cũng đặt ra những vấn đề cần phải xem xét để đảm bảo sự khác biệt và gắn kết đối với thị trường Các-bon quốc tế:

Xác định tính bổ sung: đối với việc bán tín chỉ Các-bon ra thị trường quốc tế, điều kiện bắt buộc là phải chứng minh được tính bổ sung (khi có thêm nguồn chi trả thì giá trị bổ sung trong việc tạo ra dịch vụ là bao nhiêu ?). Hiện nay, PFES tại Việt Nam đã có chi trả cho dịch vụ nước, điện và du lịch sinh thái. Việc chi trả dịch cho Các-bon được coi thêm là nguôn thu bổ sung cho cùng một diện tích rừng cung ứng nhiêuu loại dịch vụ. Tuy nhiên về mặt phương pháp luận, sẽ rất khó có thể chứng minh được tính bổ sung của việc chi trả cho Các-bon sẽ giúp nâng cao chất lượng và số lượng Các-bon bởi trong trường hợp không có chi trả cho Các-bon này, với chi trả hiện có cho dịch vụ nước và điện, rừng cũng sẽ cung cấp số lượng và chất lượng Các-bon như vậy. Để giải quyết được vấn đề này, nhiều quốc gia đã phân biệt rõ giữa diện tích rừng tạo ra dịch vụ cũng như đối tượng hưởng lợi của hai thị trường này. Ví dụ, nếu chương trình PES Các-bon nội địa chi trả cho diện tích rừng ở phía Bắc thì chương trình chi trả dựa vào thị trường Các-bon quốc tế (REDD+, FCPF) sẽ chi trả cho diện tích rừng ở phía Nam. Một số nước cũng lựa chọn mở rộng phạm vi của chương trình PES quốc gia. Ví dụ trước đây, với nguồn tài chính từ chương trình PES nội địa chỉ có thể chi trả cho diện tích đất rừng được bảo vệ thì với nguôn tài chính từ thị trường quốc tế sẽ trả thêm cho cả diện tích đất suy thoái hiện đang thực hiện các biện pháp nông lâm kết hợp để biến các diện tích đó thành rừng. Các hoạt động trên sẽ giúp quốc gia dễ dàng hơn trong việc xác định tính bổ sung mà thị trường quốc tế yêu cầu.

Hoàn thiện hệ thống quản lí PFES nội địa xây dựng hệ thống đăng kí Các-bon rừng quốc gia để thuận lợi cho viêc tham gia thị trường quốc tế. Báo cáo này chỉ ra rằng các quốc gia hiện nay trên thế giới, nếu có chương trình PES, đều sử dụng hệ thống này để nhận và phân chia lợi ích và quyên có được từ thương mại Các-bon. Tuy nhiên để làm được điểu này hệ thống quản lí PFES nội địa cần phải được hoàn thiện hơn để đón đầu các giao dịch quốc tế. Cụ thể hơn, hệ thống theo dõi, giám sát và đánh giá hiện nay chỉ bao gồm diện tích rừng cung ửng dịch vụ môi trường, số lượng người sử dụng, người hưởng lợi. Như các bài học kinh nghiệm của Brazil hay Costa Rica cũng thực hiện PES như Việt Nam cho thấy, hệ thống PES có thể được nâng cấp thành hệ thống đăng kí bán tín chỉ Các-bon hoặc hệ thống đăng kí REDD+ quốc gia nếu bổ sung các thông tin khác bao gôm: trũ lượng Các-bon tạo ra hoặc hấp thụ, diện tích nào do ai chi trả và đã chi trả được bao nhiêu, số series đã được cấp cho tín chỉ Các-bon tạo ra từ diện tích rừng này, số lượng tín chỉ Các-bon đã được cấp và bán cho ai cũng như số lượng Các-bon tiềm năng và số lượng có thể giao dịch trên thị trường quốc tế và nội địa. Việc theo dõi, giám sát và thẩm định này sẽ giúp Việt Nam hay các tỉnh cung cấp thông tin và tín hiệu thị trường rõ ràng hơn đối với người mua trong và ngoài nước tiềm năng cũng như giúp Chính phủ Việt Nam quản lí việc phân bổ hạn mức và quyền Các-bon cũng như đảm bảo tính minh bạch trong việc báo cáo nhằm tránh việc báo cáo và hưởng lợi hai lần của các bên có liên quan. Ngoài ra, việc này cũng giúp Chính quyền cấp tỉnh xây dựng nhiều phương án thương mại xem bán ở đâu, vào thị trường nào sẽ đem lại hiệu quả cao hơn. 
Tối ưu hóa nguồn tài chính để hỗ trợ quá trình thẩm định và bán tín chỉ Các-bon ra thị trường quốc tế. Một diện tích có thể cung cấp lượng tín chỉ Các-bon nhiêuu hơn số lượng người mua cần mua. Tuy nhiên, để có thể xác định được chính xác lượng Các-bon mà một diện tích rừng cung cấp được, các bên thẩm định vẫn phải thẩm định giá trị thực tế của cả diện tích rừng này. Việc thẩm định độc lập bởi một bên thứ 3 thường rất tốn kém nhưng lại là yêu câu bắt buộc mà người mua đặt ra. Do vậy, để tiết kiệm chi phí này, các quốc gia thường tận dụng luôn kết quả thẩm định này để bán cho nhiều người mua. Ví dụ, một diện tích rừng có thể được thẩm định cung ứng được 20 triệu tấn Các-bon nhưng người mua chỉ mua 6 triệu tấn Các-bon thì cùng lúc đó các quốc gia sẽ đăng thông báo và tìm người mua cho 14 triệu tấn còn lại. Bởi các nhà đâu tư mới có thể tiết kiệm được số tiên bỏ ra cho việc thẩm định, đây là sẽ là ưu điểm tài chính mà nhiều nhà đâu tư quan tâm và hướng tới. Cùng lúc đó Chính phủ cũng có thể giảm được chi phí giao dịch và tăng nguôn thu từ việc này.

\subsection{Hợp pháp hóa quyền và chuyển quyền Các-bon/chuyến nhượng kết quả giảm phát thải}

Như báo cáo này đã chỉ ra, có nhiều phương thức để định nghĩa về quyền Các-bon/quyền chuyển nhượng kết quả giảm phát thải cũng như chuyển nhượng các quyền này (dựa vào hệ thống luật pháp hiện nay, xây dựng một chính sách mới, xây dựng một cơ chế chia sẻ lợi ích có liên quan đến chuyển quyền, và các giải pháp kết hợp nhiều phương án). Trong bối cảnh của Việt Nam, Chính phủ dự định sẽ xây dựng một Quyết định của thủ tướng hướng dẫn về điều này. Một số vấn đề cần xem xét trong quá trình này bao gồm:

Hướng dẫn riêng cho từng chương trình đơn lẻ hay là hướng dẫn quốc gia ? Hiện nay, Việt Nam đang xây dựng hướng dẫn riêng cho việc chuyển quyên Các-bon/chuyển nhượng kết quả giảm phát thải cho Chương trình Giảm Phát Thải Bắc Trung Bộ. Tuy nhiên, báo cáo này chỉ ra rằng các quốc gia không tiếp cận theo quy mô từng chương trình đơn lẻ mà hướng tới mục tiêu xây dựng một quy định và hướng dẫn chung quốc gia, áp dụng cho tất cả chương trình bao gồm chương trình ERPA. Việc xây dựng hướng dẫn chung quốc gia này sẽ đảm bảo tính thống nhất và nhất quán về mặt luật pháp giữa các chương trình đồng thời tiết kiệm chi phí và nguôn lực của các bên có liên quan.

Ai nên là người sở hữu quyền Các-bon và có trách nhiệm phân bổ quyền này cho các bên có liên quan ? Báo cáo này cho thấy có 3 cách tiếp cận của các nước liên quan đến vấn đề này:

i. Quyên Các-bon đi theo quyền và phân loại sở hũu đất công tư. Đối với diện tích rừng do nhà nước quản lí, Nhà nước sở hữu quyên Các-bon tạo ra trên diện tích rừng này. Đối với diện rừng do các bên ngoài nhà nước quản lí, toàn quyền Các-bon cũng thuộc về chủ sở hữu ngoài nhà nước này. Điều này tạo điều kiện khuyến khích các bên ngoài nhà nước tham gia vào các hoạt động thương mại giảm phát thải. Tuy nhiên trong thực tế không phải nhóm chủ sở hữu rừng nào cũng có đủ năng lực để làm điều này (đặc biệt cộng đông dân cử) do vậy vẫn cần sự hỗ trợ của nhà nước.

ii. Quyên tự chủ và tài sản quốc gia. Mặc dù theo loại hình sử dụng đất có sở hữu công và sở hửu tư, nhưng với mục tiêu đảm bảo quyên tự chủ và tài sản quốc gia, quyền Các-bon chỉ thuộc về nhà nước. Các bên ngoài nhà nước có quyền hưởng lợi từ việc bán cây đứng, quyên sử dụng lâm sản, quyền chuyển giao các tài sản liên quan đến gỗ và dịch vụ môi trường nhưng không có quyền sở hưu hoặc chuyển giao quyền Các-bon. Nói cách khác, quyền Các-bon được tách ra khỏi các quyền hưởng lợi hiện nay của các chủ rừng này. Tuy nhiên, Nhà nước có thể kí chuyển nhượng quyền cho các bên có liên quan. Các kết quả nghiên cứu từ báo cáo này cho thấy trong trường hợp quyền Các-bon thuộc về quốc gia, các quốc gia hoặc sẽ phê chuẩn một Bộ ngành cụ thể (Bộ Tài Chính - nơi quản lí dòng tài chính liên quan đến thương mại phát thải; hoặc Bộ Ngoại Giao - đơn vị quy định hướng dẫn các hoạt động đối với quốc tế - hoặc Bộ Môi trường/Bộ Nông Lâm Nghiệp chịu trách nhiệm hướng dẫn điều phối các hoạt động kĩ thuật giảm phát thải). Việc lựa chọn Bộ ngành nào chịu trách nhiệm phụ thuộc rất nhiều vào chức năng nhiệm vụ được giao của mỗi nước, cũng như năng lực và sức mạnh ảnh hưởng của các bên này trong quá trình đàm phán.

iii. Mô hình chia sẻ lợi ích. Cơ chế chia sẻ lợi ích đóng vai trò quan trọng trong việc quyết định 
quyền các-bon thuộc về ai. Có 3 phương án chính liên quan đến hệ thống chia sẻ lợi ích và chuyển quyền các-bon mà các quốc gia đang áp dụng: i) cơ chế chia sẻ lợi ích ở quy mô quốc gia- trong đó Chính quyền trung ương (đại diện bởi một Bộ hoặc cơ quan nhà nước cụ thể) là nơi toàn quyền điều phối và phân bổ lợi ích tới các bên hưởng lợi; (ii) cơ chế chia sẻ lợi ích theo quy mô quốc gia nhưng được thực hiện và đóng góp bởi chính quyền cấp địa phương kết hợp với các chương trình dự án; (iii) cơ chế chia sẻ lợi ích theo mô hình dự án và chương trình. Đối với trường hợp (ii) và (iii) nhà nước sẽ phải làm rõ quá trình chuyển quyền các-bon.

Báo cáo chỉ ra rằng phương án 2 được phần lớn quốc gia lựa chọn để đảm bảo tính tự chủ của chính quyền quốc gia, tiết kiệm chi phí và nguồn lực giao dịch trong việc thiết kế, giám sát và điều hành đông thời hạn chế các rủi ro trong khiếu kiện (càng nhiều bên sở hữu quyền Các-bon càng có nhiều tiềm năng tranh chấp trong vấn đề hưởng lợi. Tuy nhiên, nếu chỉ có một chủ sở hữu chính phân bổ lại quyền Các-bon qua hệ thống giấy chứng nhận và cấp phép sẽ giảm đi các xung đột). Các nước chỉ chọn phương án 1 khi hệ thống sở hữu tư phát triển mạnh mẽ và là trụ cột của chính trị quốc gia, có mâu thuẫn xung đột xã hội lớn giữa các nhóm trong xã hội, các cơ quan nhà nước và ngoài nhà nước đạt được thỏa thuận trong cơ chế chia sẻ lợi ích và cấp chứng chỉ quyền Các-bon thuận lợi.

Với các phân tích chính sách hiện hành tại Việt Nam, Bộ Nông Nghiệp Và Phát Triển Nông Thôn (Bộ NN-PTNT) đang xem xét giải pháp Ủy Ban Nhân Dân các tỉnh sẽ chuyển quyền Các-bon với vai trò là chủ sỡ hữu công ở cấp tỉnh cho Bộ NNPTNT (chính quyền trung ương và là bên thực hiện dự án) trong khuôn khổ của Chương trình giảm thải Bắc Trung Bộ. Phương án này, nếu áp dụng cho khuôn khổ chương trình ERPA như một dự án thì sẽ phù hợp với xu thế các nước đang lựa chọn, đó là cơ quan nhà nước sở hữu toàn bộ quyền Các-bon. Tuy nhiên, có hai vấn đề cân xem xét:

\section{i. Bộ NN-PTNT là bên cấp hay bên nhận} quyền ? Như đã trình bày ở trên, việc xây dựng một quyết định cho một dự án hay chương trình đơn lẻ có rất nhiều hạn chế mà cân tiến tới việc xây dựng một quy định chung cho toàn quốc gia mà mọi chương trình dự án đều phải thuân thủ để đảm bảo tính thống nhất. Trong trường hợp này, theo mô hình các quốc gia khác đang áp dụng, Bộ NN-PTNT không chỉ đóng vai trò là bên thực hiện Chương trình mà còn là đại diện của Nhà nước Việt Nam sở hữu và có quyền chuyển giao quyền Các-bon và giảm phát thải Các-bon rừng. Nói cách khác, Bộ NNPTNN, đại diện cho Chính phủ Việt Nam sẽ cấp phép quyển giảm phát thải cho các bên (chính quyền tỉnh, các dự án, v.v.) qua một quy trình đăng kí và cấp phép riêng chứ không phải nhận giấy ủy quyền của chính quyền cấp tỉnh.

ii. Nếu trong trường hợp UBND tỉnh chuyển quyền cho Bộ NN-PTNT trong khuôn khổ dự án, họ sẽ chuyển quyền bao nhiêu tín chỉ Các-bon/kết quả giảm phát thải hay tất cả ? Trong trường hợp UBND tỉnh chuyển quyền Các-bon về Bộ NN-PTNT, UBND sẽ phải nêu rõ quyền Các-bon với bao nhiêu lượng Các-bon sẽ chuyển trong dự án này. Tuy nhiên, vì còn phải trải qua quá trình thẩm định nên chưa rõ con số này là bao nhiêu, đồng thời nếu tiến hành theo quy mô dự án thì Tỉnh sẽ phải gửi lại cho Bộ giấy chuyển quyên Các-bon khác trong dự án mới. Điều này không những gây khó khăn trong việc hoàn thiện giấy phép chuyển quyền mà tạo ra chi phí giao dịch cao. Trong khi đó nếu chọn giải pháp Quyết định hướng dẫn chung quốc gia và qua mô hình cấp phép có thể giảm thiểu được điêu này.

\section{Chuyển quyền Các-bon và đóng góp vào}

NDC. Một điểm quan trọng cân cân nhắc đó là việc chuyển quyền Các-bon sẽ có ảnh hưởng thế nào tới việc quốc gia thực hiện cam kết NDC. Như đã thảo luận ở báo cáo này, nhiêu bên mua quyền giảm phát thải để thực hiện cam kết NDC của họ. Do quy định của Thỏa Thuận Paris không được tính hai lần nên nếu đã bán cho nước ngoài thì Việt Nam không có quyên báo cáo kết quả giảm phát thải này vào kết quả thực hiện NDC của mình. Nếu đặt mục tiêu thực hiện NDC là ưu tiên, cần tính toán cụ thể cần bao nhiêu lượng phát thải của ngành lâm nghiệp để đảm bảo cam kết NDC cũng như bao nhiêu lượng Các-bon có thể chuyển quyền mà không ảnh hướng đến cam kết tự nguyện quốc gia.

Xây dựng năng lực cho hệ thống đăng kí và chuyển quyền Các-bon. Báo cáo này chỉ ra rằng, các quốc gia đều thiết lập và năng cao 
năng lực cho một cơ quan nhà nước làm đâu mối trong việc đăng kí, chuyển quyên Các-bon, thẩm định và giải quyết các tranh chấp có liên quan đến quá trình đăng kí này. Cơ quan này sẽ hoạt động dựa trên một phần ngân sách nhà nước cũng như từ phí hành chính và quản lí có được từ các bên nộp đăng kí cấp phép, cũng như các hoạt động thẩm định, giám sát và cấp phép.

Quyền phải đi đôi với trách nhiệm. Kết quả nghiên cứu trong báo cáo cho thấy, các chính sách liên quan đến chuyển quyền Các-bon phải gắn kết giữa quyền hạn và trách nhiệm. Các quyền hạn và lợi ích được giao cho các bên nhưng nếu các bên không thực hiện đúng chức năng nhiệm vụ và cam kết giảm phát thải của mình thì phải chịu những hình phạt. Ví dụ như các cơ chế thương mại phát thải tại các nước Châu Âu quy định, các bên có quyên hưởng lợi từ việc mua bán giảm phát thải nhưng nếu không đạt được mục tiêu đề ra sẽ phải nộp phạt tài chính đông thời chịu những trách nhiệm hình sự theo quy định. Điều này để đảm bảo tính hiệu quả của các chương trình và chính sách giảm phát thải.

Việt Nam đã có nhiều khung pháp lí liên quan đến bảo vệ môi trường và phát triển bền vững. Tích hợp và xem xét các bài học quốc tế phù hợp với bối cảnh Việt Nam sẽ giúp quốc gia xây dựng các phương án phù hợp. 


\section{Tài liệu tham khảo}

Adler K. 2020. UK emissions trading system to launch on 1 January 2021. Available at: https://ihsmarkit.com/research-analysis/ukemissions-trading-system-to-launch-on-1january-2021.html

Agence France Trésor'. 2021. The carbon market. Available at: https://www.aft.gouv.fr/en/ carbon-market

Benn V, Pham TT, Moeliono M, Maharani C, Thomas R, Chesney P, Dwisatrio B, Ha CN. 2020. The context of REDD+ in Guyana: Drivers, agents and institutions. Occasional Paper 201. Bogor, Indonesia: CIFOR.

Blyth W and Bosi. 2004. Linking non-EU Domestic Emission Trading Schemes with the EU Emissions Trading Scheme. Paris, France.

Clapp C, Leseur A, Sartor O, Briner G and Morlot JC. 2010. Cities and Carbon Market Finance: Taking Stock of Cities' Experience With Clean Development Mechanism (CDM) and Joint Implementation (JI). OECD Environment Working Papers, No. 29, OECD Publishing, Paris. https://doi. org/10.1787/5km4hv5p1vr7-en

Council of the European Union. 2020. Draft submission to the UNFCCC on behalf of the European Union and its Member States on the update of the nationally determined contribution of the European Union and its Member States. https://data.consilium. europa.eu/doc/document/ST-14005-2020INIT/en/pdf

Dender KV. 2017. Carbon prices are still far too low to prevent climate change. Centre for Tax Policy and Administration.

[FAO] Food and Agriculture Organization of the United Nations. 2019. Chile REDD + Resultsbased payments RBP (2014-2016). http:// www.fao.org/3/ca6470en/ca6470en.pdf

[FCPF] Forest Carbon Partnership Facility. 2018. Guidance Note on the Ability of Program Entity to Transfer Title to Emission Reductions. https://www. forestcarbonpartnership.org/sites/fcp/files/2019/ July/FCPF\%20Guidance\%20Note\%20on\%20 the $\% 20$ Ability $\% 20$ of $\% 20$ Program $\% 20$ Entity $\% 20$ to $\% 20$ Transfer\%20Title\%20to\%20Emission\%20 Reductions_2018.pdf

FCPF. 2020. Forest carbon partnership facility 2020 annual report. Washington, DC. https:// www.forestcarbonpartnership.org/system/files/ documents/FCPF\%202020\%20Annual\%20 Report_Web_update.pdf

FCPF \& Chính phủ Chile. 2016. Thỏa thuận ký kết ERPD giữa chính phủ nước Chile và The Forest Carbon Partnership FCPF https://www. forestcarbonpartnership.org/system/files/ documents/ER-PD\%20Chile-\%20Final-\%20 24\%20Octubre\%202016_0.pdf

FCPF \& Chính phủ CostaRica. 2017. Thỏa thuận ký kết ERPD giữa chính phủ các nước Costa Rica và The Forest Carbon Partnership Facility FCPF. https://www.forestcarbonpartnership.org/ system/files/documents/ERPD\%20EN_170717_ clean.pdf

FCPF \& Chính phủ Cộng Hòa Dân Chủ Congo. 2016. Thỏa thuận ký kết ERPD giữa chính phủ nước Cộng Hòa Dân Chủ Congo và The Forest Carbon Partnership Facility FCPF. https:// www.forestcarbonpartnership.org/system/files/ documents/20161108\%20Revised\%20ERPD DRC.pdf

FCPF \& chính phủ Cộng Hòa Congo. 2018. Thỏa thuận ký kết ERPD giữa chính phủ nước Cộng Hòa Congo và The Forest Carbon Partnership Facility FCPF. https://www. forestcarbonpartnership.org/system/files/ documents/Revised\%20ER-PD_English_1. pdf?fbclid=IwAR1lmEulc4qrFi_0D1f-bxN0DC Nr5GhIgaGv6DaPkJH0qurWidJgR5D0w_Q

FCPF \& Chính phủ Côte d'Ivoire. 2019. Thỏa thuận ký kết ERPD giữa chính phủ nước Côte d'Ivoire và The Forest Carbon Partnership Facility FCPF. https://www.forestcarbonpartnership. org/system/files/documents/190422-ERPD\%20 RCI\%20FV.pdf 
FCPF \& chính phủ Dominican Republic. 2019. Thỏa thuận ký kết ERPD giữa chính phủ nước Dominican Republic và The Forest Carbon Partnership Facility FCPF. https://www.forestcarbonpartnership. org/system/files/documents/Version\%20 ERPD\%2021\%20Junio\%202019_FINAL\%20 \%282\%29.pdf?fbclid=IwAR3PmvTutsH5MplOTYYjp6s2RpCLYaTeFLQxEessUwGLjn1Ugo882T2sQ

FCPF \& Chính phủ Fiji. 2019. Thỏa thuận ký kết ERPD giữa chính phủ nước Fiji và The Forest Carbon Partnership Facility FCPF. https://www.forestcarbonpartnership.org/ system/files/documents/Final\%20ER-PD\%20 Fiji\%20_MASTER_v8_clean16619.pdf

FCPF \& Chính phủ Ghana. 2017. Thỏa thuận ký kết ERPD giữa chính phủ nước Ghana và The Forest Carbon Partnership Facility (FCPF).

https://www.forestcarbonpartnership.org/system/ files/documents/GCFRP_Carbon $\% 20$ Fund_Final\%20Draft_April\%2022\%20 2017-formatted.pdf

FCPF \& Chính phủ Guatemala. 2019. Thỏa thuận ký kết ERPD giữa chính phủ nước Guatemala và The Forest Carbon Partnership Facility FCPF. https://www.forestcarbonpartnership. org/system/files/documents/Final\%20 ERPD\%20280519V2clean\%20b.pdf?fbclid =IwAR1WPEYM5i9IphG_6rjoJrnTIbCd KrzkDtXLl0aIilfbCZpzxMtQn5YsXKs

FCPF \& Chính phủ Indonesia. 2019. Thỏa thuận ký kết ERPD giữa chính phủ nước Indonesia và The Forest Carbon Partnership Facility FCPF. https://www.forest carbonpartnership. $\mathrm{org} /$ system/files/documents/ERPD Indonesia\%20FINAL\%20VERSION_ MAY_2019.pdf

FCPF \& Chính phủ Mexico. 2017. Thỏa thuận ký kết ERPD giữa chính phủ nước Mexico và The Forest Carbon Partnership Facility FCPF. https://www.forestcarbonpartnership.org/ system/files/documents/_

ENGLISH_6november_2017_Mx.pdf? fbclid=IwAR3EnfQusn6U_7NWEzJrLfAqt wa6qexHOV0FUXifk5te4y3Usp7vyfAeoNw

FCPF \& Chính phủ Nicaragua. 2019. Thỏa thuận ký kết ERPD giữa chính phủ nước Nicaragua và The Forest Carbon Partnership Facility FCPF. https://www.forestcarbonpartnership. org/system/files/documents/ERPD_INGLES_ 310719_VF.pdf?fbclid=IwAR2oiO4_NuAgQg KBPaAEzomySakK1AVnfO3tCQZhAp0_ f7zVYCbfsnb-vRU
FCPF \& Chính phủ Lao PDR. 2018. Thỏa thuận ký kết ERPD giữa chính phủ nước Lao PDR và The Forest Carbon Partnership Facility FCPF. https://www.forestcarbonpartnership. org/system/files/documents/LaoPDR_ERPD_ FinalDraftMay.2018-Clean.pdf

FCPF \& Chính phủ Madagascar. 2018. Thỏa thuận ký kết ERPD giữa chính phủ các nước Madagascar và The Forest Carbon Partnership Facility FCPF. https://www. forestcarbonpartnership.org/system/files/ documents/ERPD\%20EN_170717_clean.pdf

FCPF \& Chính phủ Mozambique. 2018. Thỏa thuận ký kết ERPD giữa chính phủ nước Mozambique và The Forest Carbon Partnership Facility FCPF. https://www. forestcarbonpartnership.org/system/files/ documents/Mozambique_Revised\%20 ERPD_16April2018_CLEAN.pdf

FCPF \& Chính phủ Nepal. 2015. Thỏa thuận ký kết ERPD giữa chính phủ các nước Nepal và The Forest Carbon Partnership Facility FCPF. https://www.forestcarbonpartnership. org/system/files/documents/Updated $\% 20$ Progress\%20ReportAdditional\%20 Funding\%20Request_0.pdf

FCPF \& Chính phủ Peru. 2019. Thỏa thuận ký kết ERPD giữa chính phủ nước Peru và The Forest Carbon Partnership Facility FCPF. https:// www.forestcarbonpartnership.org/system/ files/documents/ERPD\%20PERU\%20Final. pdf?fbclid=IwAR1lmEulc4qrFi_0D1f-bxN0D CNr5GhIgaGv6DaPkJH0qurWidJgR5D0w_Q

FCPF \& Chính phủ Vietnam. 2018. Thỏa thuận ký kết ERPD giữa chính phủ nước Vietnam và The Forest Carbon Partnership Facility FCPF. https://www.forestcarbonpartnership. org/system/files/documents/00_FINAL\%20 ER-PD\%20Vietnam\%205\%20Jan\%20 2018__0.pdf

Guigon P and BlueNext. 2010. Voluntary Carbon Markets: how can they serve climate policies? OECD Global Carbon Markets Workshop. https://www.oecd.org/env/cc/45153894.pdf

[GCF] Green Climate Fund. 2017. Terms of reference for the pilot programme for REDD+ results-based payments. https:// www.greenclimate.fund/sites/default/files/ document/terms-reference-pilot-programmeredd-results-based-payments.pdf

[GCF] Green Climate Fund. 2019a. Funding Proposal- FP100: REDD-PLUS results-based payments for results achieved by Brazil in the Amazon biome in 2014 and 2015. https:// 
www.greenclimate.fund/sites/default/files/ document/funding-proposal-fp100-undpbrazil.pdf

[GCF] Green Climate Fund. 2019b. Funding Proposal- FP110: Ecuador REDD-plus RBP for results period 2014.

https://www.greenclimate.fund/sites/default/ files/document/funding-proposal-fp110undp-ecuador.pdf

[GCF] Green Climate Fund. 2019c. Funding Proposal- FP120: Chile REDD-plus resultsbased payments for results period 20142016. https://www.greenclimate.fund/sites/ default/files/document/funding-proposalfp120-fao-chile.pdf

[GCF] Green Climate Fund. 2019d. Funding Proposal- FP121: REDD+ Results-based payments in Paraguay for the period 2015-2017. https://www.greenclimate. fund/sites/default/files/document/ funding-proposal-fp121-unep-paraguay. pdf?fbclid=IwAR3HNBsNHQeQc65HAxhhAEYpND78hzD9G8rFfEe2GJeqEMDUOw Cv1Flsvw

[GCF] Green Climate Fund. 2020a. GCF Handbook. Decisions, Policies, and Frameworks As agreed by the Board of the Green Climate Fund from B.01 to B.24.

[GCF] Green Climate Fund. 2020b. Result based payment for REDD+ https://www. greenclimate.fund/redd

[GCF] Green Climate Fund. 2020c. Funding Proposal- FP130: Indonesia REDD-plus RBP for results period 2014-2016. https:// www.greenclimate.fund/sites/default/files/ document/fp130-undp-indonesia_0.pdf

[GCF] Green Climate Fund. 2020d. Funding Proposal- FP134: Colombia REDD+ Results-based Payments for results period 2015-2016. https://www.greenclimate.fund/ sites/default/files/document/fp134-faocolombia_0.pdf?fbclid=IwAR167c3n _ESedp7XTQKtyWocVunlbys0IpNEqHb Bwh6uAsTFdS36fiKcG3U

[IISD] International Institute for Sustainable Development. 2020. Suriname, Norway Submit 2020 NDCs. Accessed 11 February 2020. https://sdg.iisd.org/news/surinamenorway-submit-2020-ndcs/

[INTERPOL] International Criminal Police Organisation. 2013. Guide to Carbon Trading Crime.

Kollmuss A, Zink H, Polycarp C. 2008. Making Sense of the Voluntary Carbon Market: A
Comparison of Carbon Offset Standards. WWF Germany. Availablet at: https://www. wwf.de/fileadmin/fm-wwf/PublikationenPDF/A_Comparison_of_Carbon_Offset_ Standards_lang.pdf

Lee D and Streck C. 2016. REDD+ER transactions and the Paris Agreement. https://www.forestcarbonpartnership. org/system/files/documents/ER\%20 transactions $\% 20$ and $\% 20$ the $\% 20$ Paris $\% 20$ Agreement.pdf

Loft L, Ravikumar A, Gebara MF, Pham TT, Resosudarmo IAP, Assembe-Mvondo S, Tovar JG, Mwangi E and Andersson K. 2015. Taking stock of carbon rights in REDD+ candidate countries: concept meets reality. Forests 6: 1031-1060.

[OECD] Organisation for Economic Cooperation and Development. 2016. Effective Carbon Rates Pricing $\mathrm{CO}_{2}$ through taxes and Emissions trading systems. OECD Publishing, Paris.https://doi. org/10.1787/9789264260115-en

Panda Standard Association. 2011. PANDA standard sectoral specification for agriculture, forestry and other land use (PS-AFOLU). Available at: https://winrock. org/wp-content/uploads/2016/03/ PandaStandard_AFOLU_Sectoral_ Specification.pdf

Reinaud J and Philibert C. 2007. Emissions trading: Trends and Prospects. Organisation for Economic Co-operation and Development. https://www.oecd.org/env/ cc/39725657.pdf

[RGGI] The Regional Greenhouse Gas Initiative. 2009. Emissions. https://www. rggi.org/allowance-tracking/emissions

South Pole. 2020. Final carbon market options report ICP SEMED project . https://www. ebrd.com/documents/climate-finance/ carbon-market-options

Streck C. 2020. Who Owns REDD+? Carbon Markets, Carbon Rights and Entitlements to REDD+ Finance Forests 11, no. 9: 959. https://doi.org/10.3390/f11090959

The PMR. 2015. Carbon Taxes in Action: Existing National and Subnational Jurisdictions Using a Direct Carbon Tax. Existing National and Subnational Jurisdictions Using a Direct Carbon Tax. https://www.thepmr.org/system/files/ documents/Existing\%20Carbon\%20 Tax\%20Table\%20March\%202015.pdf 
[UNFCCC] United Nations Framework Convention on Climate Change. 2020. Canada's indc submission to the Unfccc. https://www4.unfccc.int/sites/ndcstaging/ PublishedDocuments/Canada\%20First/ INDC\%20-\%20Canada\%20-\%20English.pdf

UNFCCC. 2021a. Amendment to Annex B of the Kyoto Protocol. Available at: https://unfccc. int/process/the-kyoto-protocol/amendmentto-annex-b

UNFCCC. 2021b. What is the Kyoto Protocol?. Available at: https://unfccc.int/kyoto_ protocol

[WCI] Western Climate Initiative. 2012. Final Essential Requirements of Mandatory Reporting. https://www2.gov.bc.ca/assets/ gov/environment/climate-change/ind/ quantification/wci-2012.pdf

Watson F. 2020. UK to legislate on domestic carbon market March 19. Se P Global Platts. https://www.spglobal.com/platts/en/ market-insights/latest-news/coal/031320uk-to-legislate-on-domestic-carbon-marketmarch-19

World Bank. 2020. State and Trends of Carbon Pricing 2020 (May), World Bank, Washington, DC. Doi: 10.1596/978-14648-1586-7. License: Creative Commons Attribution CC BY 3.0 IGO

World Bank. 2014. Pricing Carbon. Accessed 3 June 2014. https://www.worldbank.org/en/ programs/pricing-carbon\#CarbonPricing 

Các báo cáo chuyên đề của CIFOR chuyển giao các kết quả nghiên cứu quan trọng đối với ngành lâm nghiệp. Nội dung của báo cáo đều được đánh giá bởi các chuyên gia trong và ngoài tổ chức.

Giảm phát thải khí nhà kính từ phá rừng và suy thoái rừng (REDD+) được cộng đồng quốc tế và nhiều quốc gia đánh giá là chiến lược quan trọng và hiệu quả trong cuộc chiến chống biến đổi khí hậu. Chi trả dựa vào kết quả đối với các dự án giảm phát thải nói chung và với các dự án REDD+ nói riêng đã được đề xuất từ năm 2009 và đã có sự cải thiện đáng kể về hệ thống theo dõi, giám sát, thẩm định và đánh giá kết quả làm tiền đề cho chi trả trong 11 năm qua. Tuy nhiên, hiện có rất nhiều quốc gia, trong đó có Việt Nam đang gặp khó khăn trong việc xác định quyền các-bon và hệ thống chuyển nhượng quyền Các-bon/ giấy chứng nhận giảm phát thải. Dựa vào tài liệu thứ cấp, báo cáo này được tiến hành bởi Tổ chức nghiên cứu lâm nghiệp quốc tế (CIFOR) nhằm rà soát: (i) sự vận hành và định hướng của thị trường Các-bon quốc tế và nội địa trên toàn cầu; (ii) các quy định quốc tế có liên quan đến quyền Các-bon và chuyển nhượng kết quả giảm phát thải; và (iii) kinh nghiệm của 87 quốc gia trong việc xác định, xây dựng thị trường Các-bon cũng như chính sách liên quan đến quyền và chuyển nhượng quyền Các-bon.

\begin{tabular}{|c|c|c|}
\hline พิ1\% & $\begin{array}{l}\text { RESEARCH } \\
\text { PROGRAM ON } \\
\text { Forests, Trees and } \\
\text { Agroforestry }\end{array}$ & $\begin{array}{l}\text { Chương trình nghiên cứu CGIAR về Rừng, Cây và Nông lâm kết hợp (FTA) là chương trình nghiên cứu phát } \\
\text { triển lớn nhất trên toàn cầu nhằm nâng cao vai trò của rừng, cây, và nông lâm kết hợp trong phát triển } \\
\text { bên vững, đảm bảo an ninh lương thực và thích ứng và giảm thiểu biến đổi khí hậu. CIFOR điêuu phối FTA } \\
\text { và hợp tác với ICRAF, Liên minh đa dạng sinh hcoj quốc tế, CIAT, CATIE, CIRAD, INBAR và TBI. }\end{array}$ \\
\hline CUAN & & Các nghiên cứu của FTA cũng nhận được sự tài trợ của Quỹ Ủy thác CGIAR: cigar.org/funders/ \\
\hline
\end{tabular}
nghiên cứu sáng tạo, nâng cao năng lực của các bên đối tác, tích cực tham gia đối thoại với các bên liên quan để hỗ trợ định hình chính sách và thực tiễn tác động tới rừng và con người. CIFOR là tổ chức nghiên cứu thuộc liên minh CGIAR và chủ trì các chương trình nghiên cứu của CGIAR về Rừng, Cây gỗ và Nông lâm kết hợp (FTA). Trụ sở chính của CIFOR đặt tại Bogor, Indonesia và các văn phòng của CIFOR có mặt tại Nairobi, Kenya; Yaounde, Cameroon; Lima, Peru và Bonn, Germany. 